\title{
CAPACIDADE SELADORA E ADAPTAÇÃO MARGINAL PROPORCIONADAS POR ALGUNS MATERIAIS QUANDO UTILIZADOS EM PERFURAÇÕES NA REGIÃO DE FURCA DE MOLARES HUMANOS
}

Dissertação apresentada à Faculdade de Odontologia de Bauru, da Universidade de São Paulo, como parte dos requisitos para obtenção do título de Mestre em Odontologia, área de Endodontia.

(Edição Revisada)

BAURU

2002 


\section{CAPACIDADE SELADORA E ADAPTAÇÃO MARGINAL PROPORCIONADAS POR ALGUNS MATERIAIS QUANDO UTILIZADOS EM PERFURAÇÕES NA REGIÃO DE FURCA DE MOLARES HUMANOS}

\section{ULISSES XAVIER DA SILVA NETO}

Dissertação apresentada à Faculdade de Odontologia de Bauru, da Universidade de São Paulo, como parte dos requisitos para obtenção do título de Mestre em Odontologia, área de Endodontia.

Orientador: Prof. Dr. Ivaldo Gomes de Moraes

(Edição Revisada)

BAURU

2002 


\section{Silva Neto, Ulisses Xavier da}

Si38c Capacidade seladora e adaptação marginal proporcionadas por alguns materiais quando utilizados em perfurações de furca de molares humanos. - Bauru, 2002.

121 p. : il. ; $30 \mathrm{~cm}$.

Dissertação. (Mestrado) -- Faculdade de Odontologia de Bauru. Universidade de São Paulo.

Orientador: Prof. Dr. Ivaldo Gomes de Moraes

Data de aprovação pelo comitê de Ética em pesquisa da FOB: 27 de abril de 2001

A cópia do parecer de aprovação encontra-se no capítulo "Apêndice"

\section{Autorizo, exclusivamente para fins acadêmicos e} científicos, a reprodução total ou parcial desta dissertação/tese, por processos fotocopiadores e outros meios eletrônicos.

Assinatura: 


\section{SUMÁRIO}

LISTA DE TABELAS Xi

LISTA DE FIGURAS Xii

LISTA DE ABREVIATURAS E SÍMBOLOS XV

RESUMO Xvi

1 INTRODUÇÃO

2 REVISÃO DA LITERATURA 9

3 PROPOSIÇÃO

4 MATERIAL E MÉTODOS

4.1 Avaliação da capacidade seladora por infiltração de corante 41

4.2 Preparo dos espécimes para microscopia eletrônica de varredura 51

4.3 Fotomicrografias em microscopia eletrônica de varredura e análise da 53 adaptação do material às paredes dentinárias

$\begin{array}{ll}\text { 4.4 Materiais utilizados } & 60\end{array}$

5 RESULTADOS 66

6 DISCUSSÃO

6.1 Infiltração marginal

6.2 Discussão da metodologia 74

6.3 Discussão dos resultados 87

6.4 Considerações gerais 95

7 CONCLUSÕES 98

REFERÊNCIAS BIBLIOGRÁFICAS $\quad 100$

$\begin{array}{lr}\text { ABSTRACT } & 120\end{array}$

APÊNDICE 


\section{Dados Curriculares \\ U lisses $\mathrm{X}$ avier da $\mathrm{S}$ ilva $\mathrm{N}$ eto}

Nascimento

Filiação

$1992-1996$

$1997-1998$

$1999-2000$

$2000-2002$

Associações
25 de Novembro de 1974

São Paulo - SP.

Renato Xavier da Silva e

Carmen Luzia Xavier da Silva.

Curso de Odontologia - Pontifícia Universidade Católica do Paraná - PUC-PR.

Curso de Especialização em Endodontia na Faculdade de Odontologia de Bauru - USP.

Curso de Especialização em Periodontia na Pontifícia Universidade Católica do Paraná - PUCPR.

Curso de Pós-Graduação em Endodontia em nível de Mestrado na Faculdade de Odontologia de Bauru - USP.

ABO - PR - Associação Brasileira de Odontologia Secção Paraná

SBPqO - Sociedade Brasileira de Pesquisa Odontológica. 
À memória de meu pai RENATO, que foi meu melhor professor. Quanto mais o tempo passa, mais enxergo o quanto me ensinou.

Das tantas coisas que me ensinou, só faltou a de como viver sem você...

À minha mãe CARMEN, exemplo de paciência, dignidade e amor infinito. Este título é uma pequena retribuição a tudo que você tem feito por mim nesse meus anos de vida.

À toda minha família, especialmente minha avó ONDINA, exemplo de caráter, humildade e honestidade.

À minha querida MARIANA, pelo constante estímulo e paciência nas horas difíceis desta caminhada. Espero poder retribuir todo o amor recebido. 
Ao meu orientador, Prof. Dr. IVALDO GOMES DE MORAES, que me acolheu como um pai, com os braços e coração abertos, como meu amigo, meu conselheiro, sempre dividindo seus pensamentos e experiências. Incentivou-me a erguer a cabeça, confiar em minha capacidade e vencer os desafios.

Agradeço por mais uma vez me haver conduzido aos caminhos da pesquisa e do ensino, com uma orientação segura e precisa. Saiba que acredito ter tido o privilégio de haver assimilado um pouco de seus ensinamentos. 


\section{MEU A GRA DECIMENTO}

Ao meu "irmão" ANDRÉ DANIELIDES EGOROFF, exemplo de amigo e companheiro, sempre presente em todos os momento da minha vida. Toda minha gratidão e amizade a você CAROLINA e PEDRO.

À família LAFFITTE, Dr. Augusto, D. Regina, Luciana, Tatiana, Alexandre e Mariana por me receberem tão bem em suas vidas, pelo interesse e estímulo durante toda essa jornada. Meu eterno agradecimento.

Aos amigos sinceros e eternos, que próximos ou distantes fisicamente, sempre estiveram presentes: BALU, HUMBERTO, DIEGO, RAPHAEL, ANDRE, LEANDRO, FAÉCA, GUILHERME, RODRIGO, C.G.. Todo meu respeito e consideração. 


\section{A GR A D ECIM ENT O ESPECIAL}

À amiga, Professora e "orientadora" VÂNIA PORTELA DITZEL WESTPHALEN, pela colaboração decisiva na minha formação acadêmica, por ser a verdadeira responsável pelo meu interesse e amor a Endodontia e pela confiança e oportunidade de compor sua equipe. Pela sua integridade e honestidade demonstradas em todos esses anos de amizade, meu eterno agradecimento e consideração.

Ao amigo Prof. Dr. LUCIANO LOUREIRO DE MELO, pelo apoio e incentivo tão importantes nos meus primeiros passos e pela consideração particular a mim dedicada. A sua amizade e confiança muito me honram, e sua história e competência profissional são exemplos a serem seguidos.

Aos Professores FERNANDO HENRIQUE WESTPHALEN, MONIR TACLA e SÉRGIO ROBERTO VIEIRA, da PUC-PR pela confiança em mim depositada e pelo estímulo à realização do curso de Mestrado.

Aos Professores da Disciplina de Endodontia da PUC-PR, VÂNIA P. DITZEL WESTPHALEN, ROSILENE GOMES, ARY FERNANDO G. LOVATO E MARILI DORO DEONÍzIO, meu muito obrigado pelos ensinamentos durante o curso de graduação e pelo estímulo constante pela minha carreira universitária.

À todos os Professores do curso de Especialização em Periodontia da PUC-PR, em especial ao amigo e Prof. SUNG HYUN KIM, pelo companheirismo durante todas nossas viagens à Bauru, pela colaboração e amizade em toda as ocasiões. 
À D.CARMINHA, FERNANDA, RENATA e GUILHERME, pela atenção e amizade durante minha permanência em Bauru.

Aos amigos VICTOR HUGO DECHANDT BROCHADO e JOSÉ FRANCISCO GONÇALVES JÚNIOR, verdadeiros irmãos, parceiros constantes nessa caminhada de ensino e pesquisa. Muito aprendi com vocês, nas dificuldades, nos momentos de estudo e descontração. A convivência com vocês, ajudou-me a superar as dificuldades encontradas durante nosso curso de Mestrado.

À amiga SILVANA BELTRAMI GONÇALVES, pela convivência agradável e verdadeira desde a época de nosso curso de Especialização, até o término de mais esse desafio, todo meu carinho e gratidão.

Aos amigos, GUILHERME G. RIBEIRO, JUAN ANGEL MEDINA, VIVIANE H. BROSCO, GRAZIELA G. MORI E SÔNIA OLIVEIRA S. SCHIMPF, pelos momentos inesquecíveis de nossa convivência.

Aos colegas do Doutorado, CHRISTIAN, MAEDA, VÂNIA, CARLOS heNRIQUe, CARLOS HERRERo, PATRícIa, luciana e flaViana, pelos conselhos, ensinamentos e amizade.

Aos colegas do "Mestrado novo", LEANDRO, FERNANDA, EVERDAN, RENATO, SÉRGIO, RODRIGO, MARISTELA, JASMINA e GIOVANA, pelo convívio respeitoso e harmônico. 


\section{A GR A D E CIMENTOS}

À Faculdade de Odontologia de Bauru, na pessoa do seu diretor Prof. Dr. AYMAR PAVARINI.

À comissão de pós-graduação, representada pelo Prof. Dr. LUIZ FERNANDO PEGORARO.

Ao Prof. Dr. CLÓVIS MONTEIRO BRAMANTE, coordenador do curso de pós-graduação em Endodontia, pela paciência, carinho e oportunidade de desenvolver este trabalho.

Aos Professores ROBERTO BRANDÃO GARCIA e NORBERTI BERNARDINELI, pelos valiosos ensinamentos, dedicação e atenção. Pela forma cordial com que me receberam. A vocês toda minha amizade e respeito.

Ao Prof. Dr. ALCEU BERBERT, eterno mestre, que impulsionou meu desejo de sempre procurar alcançar o seu exemplo de dedicação ao ensino e à pesquisa.

À todos os Professores do curso de pós-graduação da FOB - USP, meus sinceros agradecimentos pela minha formação.

Ao Prof. Dr. CÉSAR ANTUNES DE FREITAS pela preciosa colaboração na confecção do material fotográfico.

Ao Prof. Dr. JOSÉ ROBERTO PEREIRA LAURIS, pela presteza e ajuda na execução da análise estatística.

Ao funcionário EDIMAURO DE ANDRADE pela indispensável participação na microscopia eletrônica de varredura. 
Ao amigo LEANDRO ZANDAVALI DEBONE, pela versão do "Abstract."

Aos pós-graduandos EVERDAN CARNEIRO e RENATO MENEZES, pelo auxílio na leitura dos resultados da infiltração marginal.

Às funcionárias do Departamento de Endodontia da FOB - USP, SUELI, NEIDE, PATRÍCIA e CLEIDE, pelo carinho e atenção.

À todos os funcionários da Biblioteca da FOB - USP, em especial à RITA, pela ajuda, atenção e amizade.

A todos amigos e colegas da pós-graduação. Nosso convívio certamente não será esquecido.

Ao CNPq, pela concessão da bolsa de estudos, que tornou possível a realização desse trabalho.

A todos que direta ou indiretamente, colaboraram para a realização deste trabalho. 


\section{LISTA DE TABELAS}

pág

Tabela 1 Distribuição das amostras e identificação dos grupos em função dos materiais utilizados

Tabela 2 Distribuição das amostras e identificação dos grupos em função dos materiais utilizados

Tabela 3 Média, desvio padrão, $1^{\circ}$ quartil, mediana e $3^{\circ}$ quartil das infiltrações dos espécimes cujas perfurações foram preenchidas somente com os cimentos

Tabela 4 Média, desvio padrão, $1^{\circ}$ quartil, mediana e $3^{\circ}$ quartil das infiltrações dos espécimes cujas perfurações foram preenchidas com a presença da matriz de gesso Paris

Tabela 5 Teste de Mann-Whitney - influência da matriz na infiltração marginal

Tabela 6 Teste de Dunn para comparação individual entre os quatro materiais na ausência da matriz de gesso Paris 68

Tabela 7 Teste de Dunn para comparação individual entre os quatro materiais na presença da matriz de gesso Paris 69 


\section{LISTA DE FIGURAS}

pág

Figura 1 Espécime perfurado após impermeabilização e confecção do alvéolo artificial em silicona pesada

Figura 2 Espécime em posição de trabalho evidenciando a condensação dos materiais na cavidade da perfuração

Figura 3 Hemisecção do espécime obturado com cimento MTA - Angelus, após imersão em rhodamine B

Figura 4 Hemisecção do espécime obturado com cimento MTA - Angelus na presença da matriz de gesso Paris, após imersão em rhodamine B

Figura 5 Hemisecção do espécime obturado com cimento ProRoot - MTA, após imersão em rhodamine $B$

Figura 6 Hemisecção do espécime obturado com cimento ProRoot - MTA na presença da matriz de gesso Paris, após imersão em rhodamine B

Figura 7 Hemisecção do espécime obturado com cimento Super-EBA, após imersão em rhodamine $B$

Figura 8 Hemisecção do espécime obturado com cimento Super-EBA na presença da matriz de gesso Paris, após imersão em rhodamine B

Figura 9 Hemisecção do espécime obturado com cimento MBP-c, após imersão em rhodamine B 
Figura 10 Hemisecção do espécime obturado com cimento MBP-c na presença da matriz de gesso Paris, após imersão em rhodamine B

Figura 11 Espécimes montados em "stubs" e metalizados para M.E.V 53

Figura 12 Filme Neopan 100 ACROS preto e branco 54

Figura 13 Fotomicrografias da adaptação marginal do cimento MTA - Angelus às paredes dentinárias da perfuração

Figura 14 Fotomicrografias da adaptação marginal do ProRoot - MTA às paredes dentinárias da perfuração

Figura 15 Fotomicrografias da adaptação marginal do SuperEBA às paredes dentinárias da perfuração

Figura 16 Fotomicrografias da adaptação marginal do cimento MBP-c às paredes dentinárias da perfuração

Figura 17 Fotomicrografias da adaptação marginal da matriz de gesso Paris (sulfato de cálcio) às paredes dentinárias da perfuração

Figura 18 Cimento MTA - Angelus (Angelus Soluções Odontológicas)

Figura 19 Cimento ProRoot - MTA (Dentsply - Tulsa Dental) 61

Figura 20 Cimento Super-EBA (Harry J. Bosworth Co.) 62 
Figura 21 Cimento MBP-c (Faculdade de Odontologia de Bauru - USP)

Figura 22 Gráfico representativo das médias dos escores das infiltrações marginais permitidas pelos cimentos testados. (sem matriz de gesso Paris)

Figura 23 Gráfico representativo das médias dos escores das infiltrações marginais permitidas pelos cimentos testados. (com matriz de gesso Paris) 


\section{LISTA DE ABREVIATURAS E SÍMBOLOS}

\begin{tabular}{|c|c|}
\hline$\%$ & porcentagem \\
\hline \pm & mais ou menos \\
\hline $\mathrm{X}$ & vezes \\
\hline$x^{-}$ & média aritmética \\
\hline g & grama \\
\hline $\mathrm{cm}$ & centímetro \\
\hline $\mathrm{mm}$ & milímetro \\
\hline $\mathrm{ml}$ & mililitro \\
\hline $\mathrm{dp}$ & desvio-padrão \\
\hline $\mathrm{h}$ & hora \\
\hline $\mathrm{n}^{0}$ & número \\
\hline $\mathrm{p}$ & significância estatística \\
\hline Q & quartil \\
\hline M.E.V. & microscopia eletrônica de varredura \\
\hline MTA & agregado de trióxido mineral \\
\hline EBA & ácido etoxybenzóico \\
\hline IRM & Material Restaurador Intermediário \\
\hline Ltda. & Limitada \\
\hline $\mathrm{pH}$ & potencial hidrogeniônico \\
\hline$\stackrel{\circ}{ } \mathrm{C}$ & graus Celsius \\
\hline EUA & Estados Unidos da América \\
\hline FOB & Faculdade de Odontologia de Bauru \\
\hline USP & Universidade de São Paulo \\
\hline $\mathrm{kV}$ & quilovolt \\
\hline rpm & rotações por minuto \\
\hline NS & Não significante \\
\hline
\end{tabular}




\section{RESUMO}

Foram analisadas a capacidade seladora e a adaptação marginal in vitro, de alguns materiais quando utilizados em perfurações na região de furca. Utilizou-se cento e quatro dentes molares humanos extraídos superiores e/ou inferiores, dos quais oitenta e oito foram usados para analisar o selamento e dezesseis para a adaptação marginal dos materiais seladores utilizados sob M.E.V. Os dentes tiveram suas coroas eliminadas em um nível logo acima do assoalho da câmara pulpar, e as raízes, logo abaixo da região de furca. Em seguida, realizou-se a impermeabilização de toda a superfície externa dos espécimes, e a sua inclusão em uma base de silicona pesada. Ao centro do assoalho de cada espécime, foi realizada uma perfuração com 1,4 mm de diâmetro. Frontalmente às perfurações, na base de silicona, foram realizadas depressões onde foram posicionadas, imediatamente antes da obturação, bolinhas de algodão padronizadas umedecidas com água destilada. Em cada grupo, formou-se 2 subgrupos, um recebendo uma matriz de gesso Paris e o outro não. As obturações das perfurações foram, então, realizadas com os seguintes materiais: Grupo I (MTA - Angelus), Grupo II (ProRoot - MTA), Grupo III (Super-EBA), Grupo IV (MBP-c). Posteriormente, os espécimes foram imersos em solução corante rhodamine $\mathrm{B} 0,2 \%$ a $37^{\circ} \mathrm{C}$, por 48 horas. Após lavagem dos espécimes e remoção da impermeabilização, os mesmos foram seccionados longitudinalmente, expondo-se as perfurações e as possíveis marcas de infiltração. A leitura da infiltração marginal, foi realizada por meio de um microscópio óptico, utilizando-se de escores numéricos - 0, 1, 2 e 3, para sua quantificação. Para visualização da adaptação marginal dos materiais obturadores 
às paredes dentinárias, os espécimes foram submetidos à mesma metodologia descrita anteriormente, exceto quanto à impermeabilização da superfície externa e a imersão na solução corante. Após a presa dos cimento os espécimes, foram submetidos ao M.E.V., obtendo-se fotomicrografias com aumento de 50 e 200X. Os resultados referentes à infiltração marginal, foram submetidos aos testes estatísticos, permitindo as seguintes conclusões: Quando utilizado isoladamente (sem a matriz), o cimento MBP-c apresentou os menores índices de infiltração marginal, seguido pelo Super-EBA, havendo diferença estatística entre esses e os cimentos ProRoot - MTA e MTA - Angelus $(p<0,001)$. Na presença da matriz de gesso Paris, o cimento MBP-c apresentou os menores índices de infiltração marginal, havendo diferença estatística entre esse e os cimentos ProRoot - MTA e MTA - Angelus $(p<0,05) ; \quad$ A matriz de gesso Paris influenciou negativamente, com diferenciação estatística $(p<0,05)$, o selamento produzido pelos cimentos SuperEBA e o MBP-c $(p<0,05)$; A utilização da matriz de gesso Paris evitou o extravasamento dos materiais seladores; Foi observada uma relação direta entre a adaptação marginal e a capacidade de selamento do material. 


\section{INTRODUÇÃO}

A manutenção e a integridade da dentição natural é essencial para a plenitude das condições estéticas e funcionais. A terapia endodôntica faz parte da última tentativa de se alcançar esta meta, e o fracasso compromete a existência do dente, acarretando desordens estéticas e funcionais.

O tratamento do sistema de canais radiculares, assim como outros procedimentos odontológicos estão, algumas vezes, associados com situações adversas, indesejáveis e imprevisíveis. É imperioso salientar que a melhor arma para se evitar acidentes e complicações é a prevenção. Assim, deve-se considerar que as técnicas e os homens, mesmo com o conhecimento, são passíveis de erros, portanto, os acidentes e as complicações podem ocorrer.

As perfurações radiculares são consideradas, na maioria das vezes, como complicações e acidentes no tratamento endodôntico e foram definidas por ALHADAINY ${ }^{05}$ em 1994 como comunicações artificiais, normalmente de etiologia iatrogênica, ou ainda de origem patológica (processo de cárie ou reabsorção), comunicando a cavidade pulpar com os tecidos periodontais. A perfuração é, com certeza, o maior temor dos que praticam a Endodontia. AUN et al. ${ }^{\mathbf{1 3}}$ (1996) salientaram ser essa condição operatória semelhante a um "fantasma" que acompanha os iniciantes e nunca abandona os mais experientes.

Embora a evolução e o aprimoramento das técnicas operatórias tenham possibilitado a redução do número de perfurações radiculares iatrogênicas, elas continuam, ainda hoje, presentes na clínica cotidiana. 
Assim, segundo CATTONI ${ }^{29}$ (1963) e ALHADAINY ${ }^{05}$ (1994) durante o acesso à cavidade pulpar, um erro na direção da abertura coronária pode determinar uma perfuração nas paredes do canal ou, em dentes multirradiculados, no assoalho da câmara pulpar. Da mesma forma, no transcorrer do tratamento, o uso incorreto dos instrumentos endodônticos, manuais ou rotatórios, podem provocar perfurações (CATTONI ${ }^{29} 1963$ e NICHOLLS ${ }^{74}$ 1962).

Entre esses acidentes, INGLE $^{53}$ (1962), por meio de controle clínico e radiográfico durante dois anos, de 1229 dentes tratados endodonticamente, diagnosticou 104 casos de insucessos, sendo que $9,61 \%$ estavam relacionados às perfurações radiculares, procedimento que significa a segunda maior causa de fracassos dos tratamentos realizados. SELTZER et al. ${ }^{88}(1967)$ encontraram que as perfurações radiculares ocorriam em 3 a 10\% dos tratamentos de canais radiculares.

KVINNSLAND et al. ${ }^{60}$ (1989), afirmaram que um elevado percentual (53\%) de perfurações, provocadas pelo profissional, é realizado durante o preparo protético; as demais (47\%) têm surgido em decorrência dos procedimentos endodônticos.

Segundo BAKLAND ${ }^{16}$, 1991 a identificação das perfurações radiculares é possível pela observação direta do sangramento, avaliação indireta do sangramento utilizando-se pontas de papel, radiografias e localizadores apicais eletrônicos.

Particularmente, as perfurações localizadas na região de furca, desencadeiam uma seqüência de eventos. Provocam danos aos tecidos periodontais de suporte, induzem a formação de tecido inflamatório e granulomatoso, reabsorção óssea, destruição das fibras periodontais e do epitélio juncional, podendo culminar com a formação de bolsa periodontal. Tais perfurações, 
apresentam os menores índices de sucesso, devido à pouca vascularização da área ${ }^{5,17,37,43,78,89,92,101}$.

Entretanto, o prognóstico das perfurações radiculares, pode ser influenciado pelos mais diversos fatores, tais como localização $05,11,35,42,43,58,61,78,84$, tamanho ${ }^{11,43,48,58,61,89}$, tempo de exposição ${ }^{11,42,43,78,84,92}$, grau de contaminação ${ }^{11,19,26,27,58,84,101}$, selamento hermético ${ }^{11,54,58,84}$, biocompatibilidade do material utilizado ${ }^{5,37,54,74,84}$, possibilidade de acesso $0^{05,35,92}$, extrusão do material para o espaço periodonta ${ }^{05,06,07,14,22,47,63,68,84}$, dentre outros.

$\mathrm{Na}$ tentativa de se obter sucesso no tratamento das perfurações radiculares, inúmeros materiais têm sido testados, como guta-percha ${ }^{04,20,61}$, amálgama de prata4,12,14,17,20,84,90,114, produtos à base de hidróxido de cálcio $^{08,19,22,26,27,48,49,64,90,94}$, produtos à base de óxido de zinco e eugenol ${ }^{22,26,27,69,115}$, materiais restauradores temporários ${ }^{09,12,90}$, hidroxiapatita $^{17,63,94}$, osso descalcificado ${ }^{46}$, cimento de ionômero de vidro $06,07,08,09,30,44,64,65,68,90,114$, resina composta $^{47,64,65}$, cimento endodôntico resinoso $0^{68,98}$, e outros.

Em 1978, OYNICK;OYNICK ${ }^{79}$ introduziram um novo material para ser usado em obturações retrógradas, composto basicamente por óxido de zinco e eugenol, resina e ácido orto-etoxybenzóico. Em 1985, os mesmos autores ${ }^{80}$ utilizaram o cimento Super-EBA no tratamento de perfurações radiculares, conseguindo resultados satisfatórios.

A divergência dos resultados nos estudos com esses materiais, não tem permitido, até o momento, a eleição do material ideal para utilização em perfurações radiculares, que segundo $\operatorname{ALHADAINY}^{05}$ (1994), deveria ser, capaz de promover um selamento adequado, não reabsorvível, radiopaco, bacteriostático e não tóxico. 
No início da década de 90, a equipe de pesquisadores da Universidade de Loma Linda, Califórnia - EUA, liderados pelo Professor Mahmoud Torabinejad idealizaram e desenvolveram um material com o objetivo de selar todas as comunicações entre o sistema de canais radiculares, e a superfície externa do dente. Este foi denominado de agregado de trióxido mineral ou MTA, constituído principalmente por trióxidos e outros óxidos minerais em menor quantidade.

A partir de então, vários estudos foram realizados com esse material analisando-se a sua biocompatibilidade ${ }^{50,51,107,108,110}$, suas propriedades físicas e químicas $^{109}$, antimicrobianas ${ }^{102}$, citotoxicidade $^{77,104}$, mutagenicidade ${ }^{56}$, capeamento pulpar $^{83}$, a análise da capacidade seladora em obturações retrógradas ${ }^{02,10,18,32,39,41,59,87,91,103,106,113,118,124}$, a adaptação marginal em M.E.V. ${ }^{59,105}$, bem como a sua utilização em perfurações radiculares ${ }^{11,49,62,73,84,93,114,115}$. Atualmente é comercializado sob o nome de ProRoot - MTA pela Denstply - Tulsa Dental ${ }^{86}$.

Estudando a composição química do MTA e do cimento Portland, ESTRELA et al. $^{38}$ (2000) concluíram que os materiais apresentavam os mesmos elementos químicos, com a exceção do óxido de bismuto encontrada no MTA. HOLLAND et al. ${ }^{51}$ (2001) avaliaram o comportamento biológico do MTA, do cimento Portland e do hidróxido de cálcio, concluindo que o mecanismo de ação dos materiais estudados eram similares entre si. Em 2001 foi introduzido no mercado odontológico nacional o MTA - Angelus.

Seguindo uma linha de pesquisa iniciada em 1984, MORAES $^{72}$ desenvolveu, na Disciplina de Endodontia da Faculdade de Odontologia de Bauru, um cimento resinoso, apresentado na forma de duas pastas, podendo ser utilizado 
tanto em obturações retrógradas ${ }^{81,91}$ como em perfurações radiculares. A este material foi atribuído o nome de MBP-c.

O grande problema na utilização da maioria dos materiais refere-se à dificuldade de limitar sua colocação no trajeto da perfuração, devido à falta de um anteparo no momento da condensação do material, ocorrendo com grande freqüência, o extravasamento deste para o espaço periodontal, fato este, que influi

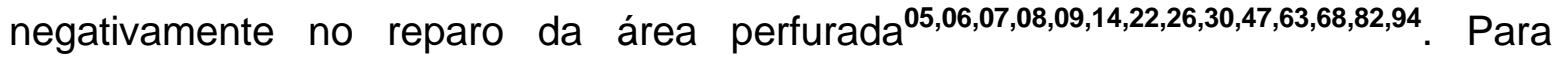
contornar este problema, muitos autores indicam a utilização de uma matriz, de modo que esta possa atuar como uma barreira ao extravasamento, permitindo uma condensação mais eficiente do material selador e evitando a presença de umidade no local da perfuração $06,07,14,22,30,47,63,68,82,90,93$. Muitos materiais, com características particulares, têm sido empregados como matriz no tratamento de perfurações na região de furca. Dentre eles, destaca-se a lâmina de índio ${ }^{04,14}$, fragmentos de dentina $^{82}$, osso descalcificado ${ }^{46}$, hidroxiapatita ${ }^{06,63}$, cimento de fosfato de cálcio ${ }^{30}$, hidróxido de cálcio ${ }^{22,64,82,90}$, materiais restauradores temporários ${ }^{12,90}$, gelfoam $^{93}$.

Nos últimos anos, o gesso Paris (sulfato de cálcio), tem sido usado como matriz no tratamento de perfurações de furca por ALHADAINY; HIMEL ${ }^{07}$ (1994), HIMEL; ALHADAINY47 (1995), ALHADAINY; ABDALLA ${ }^{06}$ (1998), MITTAL; CHANDRA; CHANDRA ${ }^{68}$ (1999), com objetivo de se evitar o extravasamento de material e favorecer o processo de reparo. Trabalhos como os de $\mathbf{B A H N}^{15}$ (1966) e YAMAZAKI et al. ${ }^{122}$ (1988), exaltam as propriedades biológicas deste material e defendem a utilização do gesso Paris.

Talvez estas preocupações justifiquem o uso de materiais que, em contato com os tecidos inter-radiculares, não venham representar, pela sua agressão física e/ou química, um obstáculo ao reparo dessa área ${ }^{94}$. 
Assim, torna-se oportuno analisar a capacidade de selamento e a adaptação marginal proporcionadas por alguns materiais utilizados no tratamento de perfurações na região de furca, pois sendo uma condição clínica passível de acontecimento em toda terapia endodôntica, independentemente da qualificação do profissional que a executa.

Partindo dessas premissas e buscando subsídios para viabiliza-las passamos à literatura específica e pertinente, cujos resumos são apresentados no capítulo seguinte. 


\section{REVISÃO DE LITERATURA}

FRANK $^{42}$, em 1983, discorrendo sobre perfurações radiculares afirmou que, com exceção daquelas causadas por reabsorções, as mesmas são resultantes de erros operatórios. O autor considera como fatores principais intervenientes no prognóstico, a localização e o tempo decorrido entre a perfuração e o tratamento. 0 prognóstico para a perfuração é favorável se ela estiver situada totalmente para coronal ou bem dentro do osso alveolar, porque uma boa quantidade de osso permanece após o tratamento, prevenindo a formação de bolsa periodontal. $\mathrm{O}$ comprimento existente entre a junção cemento/esmalte até a furca é um fator importante no reparo de perfurações do assoalho da câmara pulpar. As perfurações devem ser tratadas o mais rapidamente possível; retardar o tratamento pode resultar no estabelecimento de um problema periodontal e na ausência de osso para formar uma matriz para condensar o material obturador.

STABHOLZ et al. $^{96}$, em 1985, estudaram a adaptação marginal de obturações retrógradas, e sua correlação com a capacidade de selamento, em função do cimento de fosfato de zinco, Restodent, Durelon, Cavit-w, e amálgama. Todas as obturações retrógradas realizadas foram avaliadas quanto a sua adaptabilidade marginal em microscópio eletrônico de varredura utilizando magnificação de 48, 300, 600 e 1000X. Os autores observaram em muitos espécimes originais, rachaduras da estrutura dental, que aumentavam as fendas marginais. Em função dessa observação, realizaram réplicas das amostras antes de sofrerem essas rachaduras, que de qualquer forma melhorava as condições de leitura dos desajustes nas interfaces. Todos os materiais exibiam áreas de melhor ou 
pior adaptação, assim como, a presença de artefatos de técnica que manchavam ou obstruíam a visibilidade da área. Os resultados mostraram que o Restodent selou significantemente melhor que os outros quatros materiais e demonstrou a melhor adaptação às paredes cavitárias, enquanto o amálgama foi significantemente inferior aos quatro outros materiais em relação à adaptação marginal e ao selamento.

OYNICK; OYNICK ${ }^{80}$, em 1985, apresentaram uma técnica para tratamento de perfurações endodônticas em que, pela primeira vez, o cimento Super-EBA foi empregado como alternativa ao amálgama de prata. Este material é de fácil manipulação, compatível biologicamente com os tecidos periapicais, apresenta baixa solubilidade e elevada adesão às paredes dentinárias. Estudos prévios indicaram que pode ser usado tanto para o selamento de perfurações do assoalho da câmara pulpar como para aquelas localizadas dentro do canal radicular.

Um estudo in vitro da infiltração de corante foi realizado por BONDRA et al. $^{24}$ em 1989, comparando a capacidade de selamento do amálgama, IRM e o cimento Super-EBA, quando utilizados em obturações retrógradas. Cinqüenta e um dentes anteriores extraídos tiveram seus canais instrumentados e, então, obturados com guta-percha. Os 3mm apicais das raízes foram seccionados e os preparos apicais confeccionados com $2 \mathrm{~mm}$ de profundidade. As raízes foram, então, divididas aleatoriamente em três grupos e retroobturadas com os materiais experimentais. Após 72 horas em imersão em tinta da Índia, os dentes foram tornados transparentes por meio da técnica da diafanização, e a infiltração foi avaliada com um estereomicroscópio. Três dentes foram utilizados como controle positivo e, outros três como controle negativo. A análise dos resultados mostrou que o IRM e o cimento Super-EBA tiveram significantemente menos infiltração que o amálgama, e que a diferença entre o IRM e o Super-EBA não foi significante. 
AUN et al. ${ }^{12}$, em 1989 avaliaram, sob microscopia eletrônica de varredura com magnificação de 10 e 20X, quinze dentes perfurados durante o preparo do espaço para retentor intra-radicular. Os dentes foram distribuídos em cinco grupos distintos de acordo com o material utilizado: amálgama isolado, Lumicon e amálgama, N-Rickert isolado, N-Rickert e amálgama e com Lumicon isolado, objetivando encontrar aquele que apresentasse melhor adaptação marginal. Dentre as fotomicrografias examinadas, o grupo composto de Lumicon e amálgama foi o que apresentou melhor adaptação junto às paredes da perfuração.

DAZEY; SENIA ${ }^{33}$, em 1990, utilizaram 18 caninos humanos superiores, para comparar in vitro a capacidade de selamento de materiais como o amálgama (Tytin), Ketac-Silver e o Dycal, quando utilizados em perfurações radiculares laterais. Cada dente foi seccionado longitudinalmente obtendo-se duas metades iguais. Quinze fragmentos formaram o Grupo I, quinze o Grupo II e seis o controle. Posteriormente, foram realizadas duas perfurações, anguladas apicalmente, com o objetivo de simular um acidente de procedimento, em cada fragmento. A primeira perfuração foi realizada localizando-se no terço cervical da raiz e a segunda no apical e paralela à primeira. Dez das 30 perfurações do Grupo I e dez das do Grupo II foram obturadas com Dycal. O mesmo ocorreu com o KetacSilver e com o amálgama Tytin. Assim, cada material foi utilizado em 20 perfurações. Em seguida, as metades foram imersas em solução corante de azul de metileno a 2\% por 10 dias, e a infiltração linear medida. A análise dos resultados mostrou que o grupo do Dycal infiltrou significantemente menos que os outros grupos. Nenhuma diferença foi encontrada entre os grupos do amálgama e Ketac-Silver.

BRAMANTE et al. $^{25}$, em 1990, examinaram, por intermédio da microscopia eletrônica de varredura, alguns materiais utilizados em obturação 
retrógrada, chamando, principalmente atenção para a adaptação dos mesmos ao preparo cavitário apical. Utilizaram 35 caninos superiores extraídos, que tiveram seus canais instrumentados e obturados com guta-percha e óxido de zinco e eugenol. Os dentes foram apicectomizados, cavidades retrógradas confeccionadas e divididos em grupos de acordo com o material a ser utilizado na obturação retrógrada: amálgama, óxido de zinco e eugenol, Super-EBA, N-Rickert, IRM, gutapercha e ionômero de vidro. Posteriormente, foram avaliados no M.E.V. em relação à adaptação marginal às paredes cavitárias, com aumento de $30 \mathrm{X}$ e 100X. A avaliação foi realizada estabelecendo-se escores, onde $0 n^{\circ} 1$ representava um desajuste total em relação às paredes, o $n^{\circ} 2$, correspondia a um desajuste parcial, em que parte se adaptava muito bem, e parte se desajustava; finalmente o escore $n^{\circ} 3$, significava uma adaptação total às paredes cavitárias. Os resultados permitiram concluir que o $\mathrm{N}$-Rickert foi, o que melhor se adaptou à cavidade com uma superfície bastante lisa e uniforme. O Super-EBA se comportou de maneira similar ao N-Rickert, sendo ligeiramente inferior. De um modo geral, apresentou uma superfície parcialmente lisa, porém com algumas áreas irregulares. A guta-percha e o ionômero de vidro apresentaram uma deficiente adaptação às paredes cavitárias e o óxido de zinco e eugenol, amálgama e o IRM apresentaram adaptação ligeiramente superior à guta-percha e ao ionômero, porém exibiram superfície muito irregular.

LEMON $^{63}$, em 1992, estudando a reparação não cirúrgica de perfurações radiculares, desenvolveu e descreveu o conceito da matriz interna, no qual uma camada de um material intermediário (hidroxiapatita) seria colocada na perfuração, de modo que formasse uma barreira não removível. O objetivo da aplicação da matriz interna, era permitir o assentamento e condensação do material 
obturador, evitar a contaminação do material com sangue, prevenir os extravasamentos e aumentar o índice de sucesso em perfurações radiculares.

BERNARDINELI $^{21}$, em 1993, avaliou, por meio de microscopia eletrônica de varredura, a adaptação da obturação retrógrada às paredes das cavidades e a infiltração marginal, em função de materiais obturadores e agentes de limpeza. Foram utilizados 180 caninos humanos extraídos que, após a eliminação da porção coronária, preparo químico-mecânico, obturação dos canais e ressecção apical de $2 \mathrm{~mm}$ foram impermeabilizados com uma camada de Araldite e uma camada de esmalte para unhas, exceto a porção apical. Foram preparadas cavidades apicais com broca $n^{\circ} 2$, distribuindo-se os espécimes em grupos conforme o tipo de irrigação que receberam durante o preparo: soro fisiológico, hipoclorito de sódio a $1 \%$ e soro fisiológico, após aplicação previa de EDTA, por 3 minutos. Posteriormente, após a secagem as cavidades foram obturadas com : Pasta Lysanda, Coe-Pak, Chelon-Silver, Cimento Super-EBA, cimento de N-Rickert e Renew fotopolimerizável. Em seguida, os espécimes foram imersos em solução corante de azul de metileno a $2 \%$ por 24 horas. Após a lavagem do corante e dos espécimes, procedeu-se a metalização sendo, então, levados ao microscópio eletrônico de varredura onde foram obtidas fotomicrografias com 75X de aumento, para avaliação da adaptação de cada um dos materiais retrobturadores às respectivas cavidades. A seguir os espécimes foram desgastados no sentido vestíbulo-lingual, onde se registrou os índices de infiltração apical. Após a análise dos resultados o autor concluiu que em relação ao desajuste, entre as soluções irrigadoras não houve diferença estatística significante. Em relação ao desajuste, entre os materiais retroobturadores: a) Pasta Lysanda e Renew foram equivalentes entre si e melhores do que os demais; b) Super-EBA e N-Rickert foram equivalentes 
entre si e piores que os demais. Em relação às infiltrações marginais, a utilização do soro fisiológico possibilitou menores índices do que os demais. A infiltração marginal foi significantemente menor com o Renew, Pasta Lysanda e Coe-Pak, em relação aos demais. O cimento $\mathrm{N}$-Rickert e Super-EBA, foram equivalentes entre si e melhores do que o Chelon-Silver. Houve diferença estatística significante entre o NRickert e o Chelon-Silver, que foi o pior dos cimentos. Quanto à correlação entre desajustes e infiltração marginal, ela foi positiva em relação ao soro fisiológico e negativa em relação ao hipoclorito de sódio a $1 \%$.

A capacidade de selamento de três materiais utilizados na reparação de perfurações radiculares laterais foi estudada por MOLONEY; FEIK; ELLENDER $^{69}$, em 1993. Utilizaram 35 dentes humanos unirradiculados que tiveram suas coroas seccionadas, os canais radiculares instrumentados e obturados e perfurados no terço apical e,então, divididos em três grupos experimentais de 10 dentes cada; 5 dentes foram utilizados como controle (positivo e negativo). As obturações das perfurações laterais, foram realizadas com: amálgama mais verniz cavitário, Super-EBA e cimento de ionômero de vidro reforçado com prata. As raízes foram implantadas no tecido subcutâneo de ratos por 5 dias, com o objetivo de simular um ambiente clínico. Posteriormente, foram colocadas em uma solução contendo $20 \mu \mathrm{Ci} / \mathrm{ml}$ de cálcio 45 por 7 dias para o selamento ser avaliado. As raízes foram lavadas, seccionadas e procederam-se autorradiografias das perfurações, com tempo de exposição de 48 horas. As autorradiografias foram projetadas em uma tela e a extensão de penetração do radioisótopo mensurada. A análise estatística mostrou, que o grupo do cimento Super-EBA exibiu significantemente menos infiltração que o grupo do cimento de ionômero de vidro. Não foi encontrada diferença estatística entre os outros grupos. Os autores concluíram que o Super- 
EBA proporcionou um selamento superior em perfurações radiculares laterais em relação ao cimento de ionômero de vidro reforçado com prata, enquanto o amálgama foi intermediário entre os dois.

ALHADAINY; HYMEL ${ }^{08}$, em 1993, realizaram um estudo onde dois materiais fotopolimerizáveis, Vitrebond e Prisma VLC Dycal, foram comparados com dois materiais quimicamente ativados, Ketac Fil e Dycal, em relação à habilidade de selar perfurações na região de furca. As cavidades de acesso, e as perfurações de furca foram realizadas em 60 dentes molares humanos inferiores e/ou superiores extraídos, por meio de uma broca esférica $n^{\circ} 2$, no centro do assoalho da câmara pulpar. Todos os dentes receberam impermeabilização com duas camadas de esmalte para unhas. O diâmetro da perfuração foi padronizada como sendo o diâmetro da broca e a profundidade dependia da espessura dentina-cemento do assoalho à região de furca. Bolinhas de algodão, foram colocadas entre as raízes na região de furca, com o objetivo de simular um campo clínico úmido; não atuando como matriz para os materiais seladores, e nem afetando a extrusão desses materiais. Os dentes foram divididos aleatoriamente em quatro grupos iguais. As perfurações foram preenchidas com os materiais testados e a cavidade de acesso com resina composta. Posteriormente, os dentes foram imersos em solução corante Erythrocina B a 2\%, por 10 dias, lavados, seccionados longitudinalmente e a penetração do corante mensurada, por meio de um estereomicroscópio com aumento de 40X. Os materiais fotopolimerizáveis permitiram significantemente menor infiltração do corante em relação aos materiais que foram quimicamente ativados.

No mesmo ano, ALHADAINY; HIMEL ${ }^{09}$ avaliaram a capacidade de selamento do amálgama, Cavit e do ionômero de vidro em perfurações na região de 
furca de 30 dentes molares humanos extraídos. As perfurações foram realizadas com broca esférica $n^{\circ} 2$ no centro do assoalho da câmara pulpar. Após a obturação das perfurações, os dentes foram imersos em solução corante Erythrocina B a $2 \%$ por 7 dias. Posteriormente, foram lavados, seccionados longitudinalmente e a infiltração linear do corante foi medida. Os resultados indicaram diferença significante entre os três materiais. O ionômero de vidro exibiu a menor infiltração seguido pelo Cavit e amálgama.

Em 1993, LEE; MONSEF; TORABINEJAD ${ }^{62}$ publicaram, o primeiro estudo referente ao agregado de trióxido mineral (MTA), um novo cimento dentário, desenvolvido na Universidade de Loma Linda, EUA, com o objetivo de selar todas as comunicações entre o sistema de canais radiculares, e a superfície externa do dente. Avaliaram a capacidade de selamento do MTA na reparação de perfurações radiculares laterais. Cinqüenta molares humanos inferiores e/ou superiores extraídos foram utilizados. As perfurações foram executadas, partindo-se da embocadura de um canal da raiz mesial, por meio de uma broca esférica $n^{\circ} 2$ de haste longa, em um ângulo de $45^{\circ}$ com o longo eixo de cada dente. O local da perfuração foi alargado com uma lima Kerr $\mathrm{n}^{\circ} 80$ até que a ponta do instrumento ultrapassasse $5 \mathrm{~mm}$ além da superfície radicular. Os dentes foram divididos aleatoriamente em quatro grupos: grupo I - 15 dentes selados com amálgama, grupo II - 15 dentes selados com IRM, grupo III - 15 dentes selados com MTA e grupo IV - 5 dentes não selados servindo como controle. Em seguida, receberam duas camadas de esmalte para unhas como impermeabilizante, exceto 1 a $2 \mathrm{~mm}$ ao redor do local da perfuração e, então, foram imersos em solução corante de azul de metileno $1 \%$ por 48 horas. Após este período, os dentes foram lavados, seccionados, e examinados em microscópio por dois examinadores. Os resultados mostraram que o agregado de trióxido mineral, 
permitiu significantemente menos infiltração que o IRM ou amálgama. O MTA apresentou uma média de infiltração de $0,28 \mathrm{~mm}$, seguido de 1,30 $\mathrm{mm}$ para o IRM e 1,52 mm para o amálgama. O MTA mostrou a menor tendência de sobreobturação.

TORABINEJAD; WATSON; PITT FORD ${ }^{113}$, em 1993, realizaram um estudo in vitro utilizando o corante fluorescente rhodamine B para avaliar a capacidade de selamento do amálgama, Super-EBA e do MTA, quando utilizados como materiais retroobturadores. Trinta dentes humanos unirradiculados, tiveram as coroas removidas, os canais instrumentados e obturados com guta-percha e cimento endodôntico. Após a aplicação de duas camadas de esmalte para unhas na superfície externa, as raízes foram seccionadas e cavidades com $3 \mathrm{~mm}$ de profundidade confeccionadas. As raízes foram divididas aleatoriamente em três grupos e as cavidades apicais preenchidas com os materiais experimentais. Todas as raízes foram, então, expostas a uma solução corante de rhodamine B por 24 horas, seccionadas longitudinalmente, e a extensão da infiltração do corante mensurada por meio de um microscópio TSM ("Tanden Scanning Reflected light microscope"). A análise estatística dos resultados mostrou que o MTA infiltrou significante menos que o amálgama e o Super-EBA.

TORABINEJAD et al. ${ }^{106}$, em 1994, avaliaram a quantidade de infiltração de corante, na presença e na ausência de sangue, em cavidades apicais preenchidas com amálgama, Super-EBA, IRM e MTA. Após a remoção das coroas de noventa dentes humanos unirradiculados extraídos, os canais radiculares foram instrumentados e obturados. As superfícies radiculares foram impermeabilizadas com duas camadas de esmalte para unhas, exceto seus $2 \mathrm{~mm}$ apicais, os quais foram seccionados. Uma cavidade apical estandardizada foi preparada em cada raiz. Cinco cavidades apicais foram preenchidas com guta-percha sem cimento, e outras 
cinco foram preenchidas com cera em bastão. Estas serviram como controle positivo e negativo, respectivamente. As oitenta raízes remanescentes, foram divididas em quatro grupos iguais e preenchidas com os materiais em teste. Para cada grupo, metade das cavidades apicais, foram secas previamente à inserção do material; e a outra metade preenchida após ter sido contaminada com sangue. Todas as noventa raízes foram imediatamente imersas em solução corante de azul de metileno a 1\%, por 72 horas, cortadas ao meio e, então, a infiltração linear do corante avaliada e analisada estatisticamente. A presença ou ausência de sangue não apresentou efeito significante na quantidade de infiltração do corante, porém, houve uma diferença significante de infiltração entre os materiais retroobturadores. O MTA infiltrou significantemente menos que os outros materiais testados, com ou sem contaminação sangüínea das cavidades apicais.

Procurando contornar os efeitos prejudiciais do extravasamento do material selador junto aos tecidos periodontais, ALHADAINY; HIMEL ${ }^{07}$, em 1994, avaliaram o uso de uma matriz de gesso Paris junto à base da perfuração de furca de molares humanos extraídos, sobre a qual seria acomodado o material selador; amálgama de prata ou ionômero de vidro fotopolimerizável. Todos os dentes receberam impermeabilização com uma camada de esmalte para unhas e em seguida foram perfurados no centro do assoalho da câmara pulpar, por meio de uma broca esférica $n^{\circ} 2$. A largura da perfuração foi padronizada como sendo o diâmetro da broca e a profundidade dependia da espessura dentina-cemento do assoalho à região de furca. Bolinhas de algodão, foram colocadas entre as raízes na região de furca, com o objetivo de simular um campo clínico úmido; não atuando como matriz para os materiais seladores, e nem afetando a extrusão desses materiais. Dez dentes serviram como grupo controle (positivo e negativo), e sessenta, foram 
divididos em quatro grupos de quinze cada. As cavidades foram preenchidas com os materiais isolados ou em associação com o gesso Paris, e em seguida, receberam outra camada de impermeabilização de esmalte para unhas, exceto nas proximidades da perfuração. Os dentes foram imersos em solução corante Erythrocina B a 2\% por 15 dias, lavados, seccionados longitudinalmente, e a infiltração medida, por meio de um microscópio com ocular micrométrica. Os resultados mostraram que o grupo do ionômero de vidro fotopolimerizável apresentou a menor quantidade de infiltração, seguido pelo grupo do ionômero de vidro sobre o gesso Paris. Os grupos que utilizaram amálgama e amálgama sobre o gesso Paris apresentaram as maiores infiltrações. Os autores observaram também, que a matriz de gesso Paris conseguiu impedir o extravasamento dos materiais.

ALHADAINY $^{05}$, em 1994, em revisão de literatura, enfatizou que as perfurações radiculares podem ser originadas por iatrogenias, reabsorções internas ou externas, ou cáries. Perfurações iatrogênicas são causadas por um acesso inadequado durante preparo do canal radicular, devido à perda da direção da broca, por super instrumentação ou pelo uso inadequado de instrumentos rotatórios. O diagnóstico de uma perfuração radicular é possível ser realizado diretamente, por meio da observação da hemorragia ou indiretamente por meio de radiografias e localizadores apicais eletrônicos. O prognóstico de um dente tratado endodonticamente, com pequena perfuração, é melhor quando a perfuração é selada imediatamente após ser encontrada; e torna-se pior quando ocorre no assoalho da câmara pulpar ou na zona de furca. O plano de tratamento para as perfurações depende de vários fatores. Algumas perfurações podem ser reparadas cirurgicamente ou por obturação convencional, executando o vedamento da perfuração, ou simulando um canal acessório. As perfurações no assoalho da 
câmara pulpar podem ser obturadas quando o acesso é possível, através da câmara pulpar. A maior dificuldade, com este método de reparo, está no extravasamento do material obturador para o espaço periodontal. Isto pode ser controlado, utilizando-se de um material biocompatível como o gesso Paris, hidróxido de cálcio, hidroxiapatita, folhas de índio ou discos de teflon, à guisa de matriz. O gesso Paris, provou ser uma boa barreira contra a extrusão de materiais utilizados em perfurações, com propriedades biológicas favoráveis.

HIMEL; ALHADAINY47, em 1995, avaliaram o efeito do ataque ácido da dentina, na capacidade de selamento do ionômero de vidro e da resina composta na presença da matriz de gesso Paris, quando utilizados em perfurações de furca. Sessenta dentes molares humanos extraídos foram divididos em quatro grupos, variando-se os materiais (ionômero de vidro e resina composta) e a preparação da dentina (com ou sem ataque ácido). Os dentes foram perfurados no centro do assoalho da câmara pulpar com broca esférica ํํ2, e, impermeabilizados com esmalte para unhas. O diâmetro da perfuração foi padronizado como sendo o diâmetro da broca e a profundidade dependia da espessura dentina/cemento do assoalho à região de furca. Bolinhas de algodão, foram colocadas entre as raízes na região de furca, com o objetivo de simular um campo clínico úmido; não atuando como matriz para os materiais seladores, e nem afetando a extrusão desses materiais. Após a obturação das perfurações, os dentes foram imersos em solução corante de azul de metileno a $2 \%$ por 15 dias. Posteriormente, foram lavados, seccionados longitudinalmente e a infiltração do corante foi medida e calculada por um programa de captação de imagens. Os resultados indicaram, que o grupo do ionômero de vidro com ataque ácido da dentina, proporcionou menores médias de infiltração do que os outros grupos com diferença estatística significante. 


\section{Em 1995, O' CONNOR; HUTTER; ROAHEN ${ }^{76}$ investigaram a} infiltração em obturações retrógradas realizadas com amálgama e Super-EBA, utilizando duas técnicas de preparo de cavidade. Sessenta e quatro dentes humanos unirradiculados extraídos, tiveram seus canais instrumentados e obturados com guta-percha, sendo, então, divididos em quatro grupos. Após a apicectomia, foram confeccionadas cavidades com $3 \mathrm{~mm}$ de profundidade, por meio de pontas ultrasônicas e brocas e, então, realizou-se as obturações retrógradas com amálgama ou Super-EBA. Os dentes receberam 3 camadas de esmalte para unhas como impermeabilizante e foram submetidos à técnica da pressão hidrostática passiva com a solução corante de azul de metileno a $1 \%$ durante 4 meses. A análise estatística dos resultados mostraram que, indiferente à técnica, o Super-EBA permitiu significantemente menor infiltração que o amálgama. Em relação às técnicas de preparo das cavidades, não houve diferença estatística significante.

TORABINEJAD et al. ${ }^{105}$, em 1995, estudaram a adaptação marginal do MTA como material retroobturador, sob microscopia eletrônica de varredura, comparando-o com materiais utilizados rotineiramente com o mesmo objetivo. Oitenta e oito dentes humanos unirradiculados extraídos, tiveram seus canais instrumentados e obturados com guta-percha e cimento endodôntico. Em seguida, foram apicectomizados e as cavidades apicais preparadas e preenchidas com amálgama, Super-EBA, IRM ou MTA. Quarenta raízes foram seccionadas longitudinalmente em duas metades. Réplicas de resina das raízes remanescentes, não seccionadas também foram preparadas. Após montar as secções longitudinais, e as réplicas de resina das raízes apicectomizadas em plataformas de alumínio, as distâncias entre os materiais retroobturadores testados, e a superfície dentinária, foram avaliadas em quatro pontos por meio de um microscópio eletrônico de 
varredura com aumento de 30X e 100X. A avaliação dos exemplares originais, mostraram numerosos artefatos nas secções longitudinais, ao contrário das réplicas de resina. A análise estatística dos dados, comparando os espaços abertos entre os materiais retroobturadores e nas superfícies dentinárias, mostraram que o MTA proporcionou melhor adaptação marginal, quando comparado ao amálgama, SuperEBA e IRM.

TORABINEJAD et al. $^{109}$, em 1995, determinaram a composição química, $\mathrm{pH}$ e radiopacidade do MTA, e também compararam-no quanto ao tempo de presa, resistência à compressão e solubilidade em relação ao amálgama, SuperEBA e o IRM. Os resultados mostraram que as principais moléculas presentes no MTA são íons cálcio e fósforo; seu pH foi de 10,2 inicialmente, aumentando para 12,5 três horas após sua mistura. O MTA apresentou-se mais radiopaco que o Super-EBA e o IRM. O amálgama ofereceu o menor tempo de presa (4 minutos) e o MTA o maior (2 horas e 45 minutos). Em um período de 24 horas o MTA apresentou a menor resistência à compressão (40Mpa) entre os materiais, contra (312,5Mpa do amálgama) porém ela aumentou após 21 dias para 67Mpa. Finalmente, exceto 0 IRM, nenhum dos materiais testados mostraram qualquer solubilidade sob as condições desta pesquisa.

Ainda no ano de 1995, ABEDI; INGLE ${ }^{01}$, escreveram uma revisão de literatura sob um novo cimento, que foi desenvolvido na Universidade de Loma Linda, EUA, com o objetivo de selar as comunicações entre o sistema de canais radiculares e a superfície externa do dente. Nesta mesma Universidade, várias pesquisas tem sido conduzidas para avaliar a conveniência deste novo cimento. Os experimentos iniciaram com estudos das propriedades físicas e de 
biocompatibilidade, seguidos por estudos clínicos. Os resultados estão sendo promissores, oferecendo possibilidades de reparo.

Em 1996, FUSS; TROPE ${ }^{43}$ sugeriram uma classificação e planos de tratamento, baseados em fatores que interferem no prognóstico das perfurações radiculares. Estas foram divididas em dois grupos, e assim classificadas: com prognóstico bom (perfurações laterais, recentes, pequenas, localizadas apicalmente ou coronalmente em relação à crista óssea) e com prognóstico ruim (perfurações de furca, antigas, amplas, e as localizadas no nível da crista óssea e da junção epitelial). Salientaram que, devido à falta de uma técnica estandardizada para o selamento desse acidente clínico, a escolha do plano de tratamento deve levar em consideração a análise dos fatores condicionantes da perfuração, isto é, localização, tamanho e época de ocorrência.

BOGAERTS $^{22}$, em 1997, realizou um estudo clínico, apresentando uma técnica não cirúrgica baseada no conceito da matriz interna, utilizando hidróxido de cálcio e Super-EBA juntos para reparar perfurações de furca, atingindo bons resultados clínicos com a utilização dessa técnica.

Em 1997, MACHADO; FERNANDES ${ }^{64}$ estudaram o selamento de perfurações na região de furca de vinte e quatro molares inferiores extraídos. Após as manobras de acesso à câmara pulpar, os dentes foram perfurados na região de furca utilizando-se de uma broca esférica $n^{\circ} 3$, impermeabilizados com cianocrilato e obturados com seis combinações de materiais à saber: grupo I - cimento N-Rickert; grupo II - cimento N-Rickert servindo como matriz à resina composta fotopolimerizável; grupo III - hidróxido de cálcio P.A. servindo como matriz à resina composta fotopolimerizável; grupo IV - cianocrilato de etila (Super Bonder); grupo V - resina composta isoladamente e grupo VI - hidróxido de cálcio P.A. servindo como 
matriz ao cimento de ionômero de vidro. Em seguida, efetuaram-se as obturações, e os dentes foram imersos em solução corante de azul de metileno $0,5 \%$, e mantidos por 36 horas em estufa a $37^{\circ} \mathrm{C}$. Após desgaste longitudinal, a área de penetração do corante foi avaliada com auxilio de um microscópio acoplado à uma câmera de vídeo, cujas imagens obtidas eram enviadas a um programa de computação gráfica (DYRACOM 3). Os resultados mostraram que o grupo do cimento de ionômero de vidro em conjunto com hidróxido de cálcio, exibiu as menores áreas de penetração do corante, com diferença significante em relação aos outros grupos.

FITZPATRICK; STEIMAN ${ }^{40}$, em 1997, avaliaram a interface entre a estrutura dental e o material retroobturador, utilizando-se do IRM e do Super-EBA. Trinta e um dentes humanos unirradiculados extraídos, foram divididos em seis grupos de cinco elementos e um serviu como controle. Os dentes tiveram os canais radiculares instrumentados, obturados com guta-percha e cimento. Em seguida, foram apicectomizados, e cavidades retrógradas foram preparadas com pontas ultrasônicas, para receber os materiais experimentais. Após a realização das retroobturações, os materiais foram brunidos, ou com bolinhas de algodão úmidas, ou com uma esfera de metal ou com broca carbide em alta rotação. A avaliação da adaptação marginal foi realizada por meio da microscopia eletrônica de varredura com aumento de 40X e 75X. As retroobturações brunidas com brocas tiveram melhor adaptação marginal que as demais. Não houve diferença significante entre a brunidura com esfera ou com o algodão umedecido ou, mesmo entre os materiais utilizados.

CHAU et al. ${ }^{30}$, em 1997, estudaram a utilização do cimento de fosfato de cálcio em perfurações na região de furca de quarenta molares humanos extraídos. As perfurações foram realizadas, no centro do assoalho da câmara pulpar, 
utilizando-se de uma broca esférica $\mathrm{n}^{\circ} 2$. Os dentes foram impermeabilizados com duas camadas de esmalte para unhas, exceto nas proximidades das perfurações, e, então, divididos em quatro grupos: grupo I - cimento de ionômero de vidro fotoativado; grupo II - cimento de fosfato de cálcio; grupo III - cimento de ionômero de vidro fotoativado sobre uma matriz de cimento de fosfato de cálcio; grupo IV controle positivo e negativo. Para a confecção da matriz, o cimento de fosfato de cálcio foi inserido no interior da perfuração, e após 15 minutos de presa inicial, se removeu de 1 a 2 mm da porção mais coronal do cimento da perfuração com a ajuda de uma cureta endodôntica e uma lima Flex-R $n^{\circ} 100$ modificada, com seu $1 \mathrm{~mm}$ apical aparado perpendicularmente ao longo eixo. Bolinhas de algodão, foram colocadas passivamente entre as raízes na região de furca, com o objetivo de simular um campo clínico úmido; não atuando como matriz para os materiais seladores, e nem afetando a extrusão desses materiais. Posteriormente, os dentes foram preenchidos com os materiais estudados, imersos em tinta da Índia por 48 horas, lavados e seccionados longitudinalmente. A penetração do corante, foi avaliada independentemente por três examinadores, e os resultados mostraram, não haver diferença estatística significante entre os três grupos experimentais. Os autores concluíram, que a utilização do cimento de fosfato de cálcio pode aumentar a biocompatibilidade, o potencial ósseo condutor, e a capacidade de selamento, favorecendo o prognóstico dos dentes com perfuração na região de furca.

SHIMABUKO ${ }^{90}$, em 1997, avaliou o selamento de perfurações de furca, quando de seu preenchimento com uma associação de materiais, em cinqüenta e seis molares humanos extraídos, por meio da análise e aferição da área de infiltração de corante, com auxilio de um método computadorizado. Todos os dentes foram impermeabilizados em toda a superfície coronária e radicular com 
cianocrilato de etila. As perfurações foram realizadas com brocas esféricas $n^{\circ} 3$, na região central do assoalho da câmara pulpar. Procurou-se simular as condições clínicas, incluindo-se as raízes dentárias em silicona pesada, obtendo-se, assim, alvéolos artificiais particularizados a cada dente, possibilitando-se uniformidade durante a colocação do material selante na perfuração e limitando a movimentação dos espécimes. Bolinhas de algodão padronizadas, umedecidas com 1 gota de água destilada, obtidas a partir de um conta-gotas, foram posicionadas entre as raízes dentárias, simulando as condições clínicas quanto ao aspecto de umidade e resistência à compressão dos tecidos de suporte. Utilizou-se Cavit ou hidróxido de cálcio P.A. como material preenchedor da base da perfuração, atuando como uma matriz ou barreira física, procurando limitar o possível extravasamento do segundo material utilizado: amálgama de prata ou cimento de ionômero de vidro fotopolimerizável, os quais preencheriam o restante da perfuração. Após as manobras de obturação, os dentes receberam mais uma camada de cianocrilato de etila e foram imersos no corante rhodamine B a $1 \%$ por 7 dias. Posteriormente, foram lavados, secos e cortados longitudinalmente. Para a análise dos resultados, utilizou-se um programa computadorizado (DYRACOM 3). Os resultados demonstraram menores médias de infiltração de corante quando utilizada a associação de hidróxido de cálcio e cimento de ionômero de vidro fotopolimerizável, apresentando-se com diferença estatisticamente significante frente à comparação com as médias dos demais grupos. As médias de infiltração nos grupos em que se utilizaram associação de Cavit e amálgama, Cavit e ionômero de vidro fotopolimerizável, ou hidróxido de cálcio e amálgama não apresentaram diferença estatisticamente significante quando comparadas duas a duas. 
A capacidade de selamento de alguns materiais restauradores (amálgama; IRM; Vitremer; Bisfil 2B; Ana Norm Liner), utilizados na obturação de perfurações radiculares laterais, foram avaliadas por $\mathbf{M A N N O C C I}$ VICHI; FERRARI ${ }^{65}$, em 1997. Oitenta e cinco molares inferiores ou superiores extraídos, foram impermeabilizados com uma camada de esmalte para unhas, e divididos em cinco grupos com 15 espécimes cada. Dez dentes serviram como grupo controle (positivo e negativo). As perfurações foram realizadas por meio de uma broca esférica $n^{\circ} 2$, seguindo da superfície mesial da câmara pulpar em direção à superfície mesial da raiz em um ângulo de $45^{\circ}$ com o longo eixo dos dentes. Em seguida, os dentes foram inseridos em blocos de silicone e um tipo de bolsa foi criada frontalmente à perfuração, permitindo uma possível extrusão do material. Com o objetivo de simular uma situação clínica, manteve-se uma esponja úmida na porção mais alta do espaço criado (bolsa). Posteriormente, as perfurações foram preenchidas com os materiais já mencionados e os dentes imersos em solução corante de azul de metileno a $2 \%$ por 48 horas. Após esse período foram seccionados e a infiltração de corante avaliada. Os resultados indicaram que o Bisfil $2 \mathrm{~B}$, produziu significantemente melhor selamento que os outros materiais.

Pesquisando a infiltração de corante no tratamento de perfurações de furca e a técnica do assoalho artificial ALHADAINY; ABDALLA ${ }^{06}$, em 1998, utilizaram cinqüenta e cinco molares humanos extraídos que, após receberem uma camada de esmalte para unhas, foram divididos aleatoriamente em três grupos de 15 dentes cada e os outros 10 dentes serviram como grupo controle (positivo e negativo). As perfurações foram realizadas no centro do assoalho da câmara pulpar, por meio de uma broca esférica $n^{\circ 2}$. Com o objetivo de simular um campo clínico úmido, bolinhas de algodão, foram colocadas passivamente entre as raízes na 
região de furca. No primeiro grupo, as perfurações foram seladas somente com uma resina modificada com ionômero de vidro (Vitrebond). Gesso Paris (sulfato de cálcio) e hidroxiapatita foram utilizados como assoalho artificial por baixo do Vitrebond, no segundo e no terceiro grupo respectivamente. Os dentes receberam outra camada de esmalte para unha, e, então, foram imersos em solução corante de azul de metileno a 2 \% por 15 dias, foram lavados, seccionados e as infiltrações avaliadas por meio de um estereomicroscópio acoplado a um analisador de imagens. Os resultados indicaram que o gesso Paris (sulfato de cálcio) e a hidroxiapatita, utilizados como assoalho artificial, melhoraram significantemente a capacidade de selamento do Vitrebond e produziram barreiras eficientes contra a extrusão dos materiais.

SLUYK; MOON; HARTWELL ${ }^{93}$, em 1998, avaliaram as propriedades de endurecimento e as características da retenção do MTA, quando utilizado como material reparador de perfurações de furca. Trinta e dois molares humanos superiores e inferiores extraídos, tiveram as coroas removidas em um nível logo acima do assoalho da câmara pulpar, e as raízes removidas logo abaixo da região de furca. A porção remanescente foi montada em uma base de resina acrílica, e, então, foram perfuradas com brocas esféricas $n^{\circ} 2$, perpendicular à cada secção da furca. A abertura foi alargada com uma broca Gates-Glidden $n^{\circ} 5$, criando uma perfuração com 1,4mm em diâmetro. Uma matriz de espuma de "Gelfoam" umedecida com solução salina foi colocada abaixo da perfuração simulando as condições clínicas. Os espécimes foram divididos aleatoriamente em quatro grupos, e as perfurações foram todas obturadas com o agregado de trióxido mineral (MTA), e, então, cobertas com mechas de algodão secas ou úmidas por 24 ou 72 horas. 0 teste de "Instron" foi utilizado para medir a forca requerida para deslocar o material 
da perfuração. A força medida mostrou que o MTA resistiu ao deslocamento em 72 horas a um nível significantemente maior que em 24 horas. A presença de umidade no local da perfuração durante a inserção, foi vantajosa, auxiliando a adaptação do MTA às paredes da perfuração, porém não houve diferença significante na retenção do MTA quando uma mecha de algodão, úmida ou seca foi colocada no interior da câmara pulpar durante o período de endurecimento (tempo de presa).

BOHSALI et al. ${ }^{23}$, em 1998, avaliaram a capacidade de selamento do Super-EBA e um compômero, Dyract, como materiais retroobturadores. Quarenta e oito dentes humanos unirradiculados extraídos, tiveram seus canais radiculares preparados e obturados com guta-percha. Os ápices radiculares foram seccionados e cavidades apicais foram preparadas. Vinte dentes foram retroobturados com Super-EBA, e outros vinte com Dyract; oito dentes serviram como controle positivo e negativo. Metade dos espécimes de cada grupo foram imersos em fucsina básica por um período de 4 semanas, o restante por um período de 12 semanas. Os dentes foram, então, embebidos em resina, seccionados, e a máxima extensão da penetração do corante foi medida. A análise dos resultados não revelou diferença significante entre os dois materiais no período de 4 semanas; no período de 12 semanas, a extensão de infiltração do corante, foi estatisticamente significante, com o Super-EBA infiltrando mais que o Dyract.

MITTAL; CHANDRA; CHANDRA $^{68}$, em 1999, avaliaram em um estudo in vitro, o efeito da utilização de gesso Paris como matriz sob materiais utilizados em perfurações na região de furca. Noventa molares humanos extraídos, foram impermeabilizados com uma camada de esmalte para unhas, e, em seguida as manobras de acesso coronário foram realizadas. Os dentes tiveram o assoalho da câmara pulpar perfurados com uma broca esférica $n^{\circ} 2$, e foram divididos em cinco 
grupos experimentais com 15 dentes cada, e um grupo controle (positivo e negativo). Uma bolinha de algodão úmida foi colocada entre as raízes na área de furca, com o objetivo de simular uma região clínica úmida; não atuando como matriz para os materiais seladores, e nem afetando a extrusão desses materiais. Nos grupos experimentais, gesso Paris foi utilizado como matriz e as perfurações seladas com amálgama, ionômero de vidro, resina composta, IRM ou um cimento endodôntico a base de resina epóxica (AH 26). Após o preenchimento das perfurações, os dentes receberam mais uma camada de esmalte para unha, e foram submersos em solução corante de azul de metileno a $2 \%$ durante 15 dias. Posteriormente, os dentes foram seccionados, e a infiltração linear do corante medida, por meio de um microscópio com ocular micrométrica. A análise estatística dos resultados, mostrou que o cimento AH 26 apresentou o melhor de selamento na presença do gesso Paris; seguido pelo IRM, resina composta e ionômero de vidro. O amálgama mostrou a pior capacidade de selamento.

Em 1999, TANOMARU FILHO et al. ${ }^{98}$ avaliaram a capacidade seladora do Sealer26 e do AHplus em obturações retrógradas. Trinta caninos humanos extraídos, tiveram seus canais radiculares instrumentados e obturados. Após a secção da porção apical radicular, foram preparadas cavidades retrógradas e as raízes foram impermeabilizadas com uma camada de Araldite e duas camadas de esmalte para unhas, exceto na superfície apical seccionada. Em seguida, as cavidades foram preenchidas com cimento de óxido de zinco e eugenol com maior proporção pó-líquido, Sealer26 com maior proporção pó-resina e o AHplus acrescido de óxido de zinco. Logo após a obturação, as raízes foram imersas em solução corante de azul de metileno a $2 \%$ por 48 horas, em ambiente a vácuo. Decorrido este período, as raízes foram lavadas, a impermeabilização removida e, então, 
seccionadas longitudinalmente. A infiltração marginal foi analisada em um perfilômetro com aumento de 20X. Os resultados obtidos mostraram que o Sealer26 e o AHplus acrescido de óxido de zinco apresentaram melhor capacidade de selamento em relação ao óxido de zinco e eugenol com diferença estatisticamente significante.

PAVAN $^{81}$, em 1999, analisou a infiltração marginal, em obturações retrógradas, utilizando 80 dentes anteriores humanos extraídos. Os dentes foram distribuídos, aleatoriamente, em quatro grupos de 20 elementos de acordo como os materiais retroobturadores utilizados. Os canais foram instrumentados e, então, obturados. Em seguida realizou-se a ressecção da porção apical e foram confeccionadas cavidades para retroobturação com broca esférica $n^{\circ} 2$ previamente preparadas, com ponta ativa de $2 \mathrm{~mm}$. As raízes foram impermeabilizadas com duas camadas de Araldite e duas de esmalte para unhas. As retroobturações propriamente ditas foram, então, realizadas com os seguintes materiais: grupo I (Polímero de mamona), grupo II (Epóxico experimental). grupo III (Super-EBA), grupo IV (ionômero de vidro). Posteriormente, os espécimes foram imersos em solução aquosa de azul de metileno a $2 \%$ a $37^{\circ} \mathrm{C}$, por 48 horas. Após lavagem das raízes e remoção da impermeabilização, as mesmas foram seccionadas longitudinalmente, expondo-se as retroobturações e as possíveis marcas de infiltração. Para avaliar a infiltração do corante os espécimes foram escaneados para utilização do programa SigmaScan, realizando, assim, as medições das infiltrações. Os resultados indicaram que o grupo que propiciou menor infiltração foi o grupo I (Polímero de mamona), seguido pelo grupo II (Epóxico experimental), grupo IV (ionômero de vidro e grupo III (Super-EBA), com diferença estatisticamente significante entre os grupos I e III. 
Em um artigo publicado no jornal da Associação Americana de Endodontia, TORABINEJAD; CHIVIAN ${ }^{112}$, em 1999, descreveram as aplicações clínicas do agregado de trióxido mineral; material que tem sido recentemente investigado, como um potencial obturador alternativo utilizado atualmente na endodontia. Inúmeras pesquisas, in vitro e in vivo, têm demonstrado que o MTA previne a microinfiltração, é biocompatível e promove a regeneração dos tecidos, quando colocado em contato como a polpa dental ou com os tecidos periodontais. Suas principais indicações são: capeamento pulpar em casos de pulpites reversíveis, pulpotomias, apicificações, reparo de perfurações radiculares não cirúrgicas e cirúrgicas, sendo, também, utilizado como material retroobturador.

Em 1999, YAMASHITA et al. ${ }^{121}$ avaliaram a infiltração marginal apical em obturações retrógradas, realizadas com cimento Super-EBA de duas diferentes marcas comerciais e cimento AHplus acrescido de óxido de zinco ou de hidróxido de cálcio. Quarenta caninos humanos extraídos, tiveram seus canais radiculares preparados e obturados. Após a realização de apicectomia, e de cavidades retrógradas preparadas com broca esférica, os dentes foram impermeabilizados como uma camada de Araldite e duas de esmalte para unhas, e divididos aleatoriamente em quatro grupos, onde foram empregados como materiais retroobturadores, os materiais acima citados. Em seguida foram imersos em solução corante azul de metileno a $2 \%$, em ambiente com vácuo por 48 horas. Após o seccionamento longitudinal, a infiltração marginal foi avaliada. Todos os materiais apresentaram infiltração apical, sem ocorrer diferença significante entre eles.

ZANETTI et al. ${ }^{124}$, em 2000, realizaram um estudo in vitro para avaliar a qualidade do selamento marginal apical promovido pelo MTA ou amálgama de prata. Após preparo biomecânico, obturação do canal, apicectomia e preparo da 
cavidade apical com unidade ultra-sônica, foram realizadas retroobturações com os materiais em quarenta dentes caninos superiores divididos em dois grupos. Após impermeabilização e imersão em corante rhodamine B por 72 horas, a clivagem dos espécimes foi realizada para que a mensuração da percolação fosse avaliada em estereomicroscópio. Os resultados mostraram que as retroobturações com MTA $(1,10 \mathrm{~mm})$ foram significantemente superiores às realizadas com amálgama $(1,95 \mathrm{~mm})$, levando os autores a concluírem que o MTA proporcionou melhor selamento que o amálgama de prata.

VINHOLES $^{114}$, em 2000, analisou a capacidade de vedamento marginal de materiais utilizados no tratamento de perfurações na região de furca de cinqüenta molares humanos extraídos. Após as manobras de acesso à câmara pulpar foram realizadas perfurações no centro do assoalho da câmara pulpar por meio de broca 3216 (KG Sorensen). Os dentes foram divididos em cinco grupos, e as perfurações obturadas com os seguintes materiais: amálgama, compômero, MTA, ionômero de vidro com ataque ácido, ionômero de vidro sem ataque ácido. Em seguida, foram impermeabilizados com duas camadas de esmalte para unha, exceto à $2 \mathrm{~mm}$ ao redor da perfuração, e, então, imersos em solução corante rhodamine B $2 \%$ a $37^{\circ} \mathrm{C}$ por 7 dias. Na seqüência do experimento, foram seccionados longitudinalmente, para avaliação qualitativa da infiltração, por meio de uma lupa estereoscópica com aumento de 30X. Os resultados mostraram que o MTA, foi o material que apresentou menor infiltração, com diferença estatisticamente significante em relação aos outros materiais.

Em 2000, HOLT; DUMSHA ${ }^{52}$ compararam a capacidade de selamento do amálgama, resina composta, Super-EBA com um material retroobturador experimental (cimento ósseo). Oitenta dentes unirradiculados extraídos, tiveram 
seus canais instrumentados e obturados com guta-percha e cimento. Após a realização da apicectomia e preparo das cavidades apicais, os dentes foram divididos aleatoriamente em 4 grupos de 20 dentes, impermeabilizados com cera pegajosa e retroobturados como os materiais acima citados. Um grupo adicional de 10 dentes foi utilizado como controle (positivo e negativo). Por um período de 2 horas, os dentes foram imersos em solução de nitrato de prata $\left(\mathrm{AgNO}_{3}\right)$, lavados em água destilada por 2 minutos e colocados em solução reveladora rápida por mais 2 horas. Após as manobras de secção da raiz, a infiltração foi medida em milímetros, por meio de um microscópio óptico. Os resultados encontrados não apresentaram diferença significante entre os grupos.

AQRABAW $^{10}$, em 2000, comparou a efetividade do selamento apical do amálgama, Super-EBA e MTA utilizando o método de infiltração de corante. Setenta e nove caninos humanos extraídos, tiveram suas coroas seccionadas, os canais instrumentados e obturados como a condensação vertical de guta-percha e cimento. Em seguida, $3 \mathrm{~mm}$ radiculares apicais foram seccionados em um ângulo de $90^{\circ}$ com o longo eixo do dente, efetuando-se, em seguida cavidades apicais de 3 $\mathrm{mm}$ de profundidade com auxilio de pontas ultra-sônicas. Após a impermeabilização com duas camadas de esmalte para unhas, em toda superfície externa, exceto nas proximidades da cavidade, as raízes foram divididas aleatoriamente em 3 grupos de 25 raízes cada, retroobturadas e imersas em solução de azul de metileno 1\% por 72 horas. Quatro raízes serviram como grupo controle positivo e negativo. Em seguida, as raízes foram, lavadas, seccionadas e a profundidade de penetração do corante foi avaliada em estereomicroscópio com aumento de 10X. A análise estatística dos resultados, mostrou diferença significante entre os grupos, sendo que $56 \%$ do grupo preenchido com amálgama e $20 \%$ do grupo preenchido com Super-EBA mostraram 
penetração de corante em áreas além do material retroobturador. O grupo do MTA não mostrou nenhuma penetração do corante, permitindo, concluir que o MTA propiciou melhores resultados do que o amálgama e o Super-EBA, quando utilizado em obturações retrógradas.

TANOMARU FILHO; MENDONÇA; TANOMARU ${ }^{99}$, em 2001, analisaram em microscopia eletrônica de varredura, a adaptação marginal de materiais utilizados no selamento de perfurações radiculares. Utilizaram quinze caninos humanos extraídos, que tiveram seus canais radiculares instrumentados e obturados. Em seguida, foram preparadas cavidades na porção lateral radicular, empregando-se brocas esféricas, e os dentes foram divididos em três grupos. As cavidades preparadas foram preenchida com cimento de óxido de zinco e eugenol, Sealer26 ou Sealapex acrescido de óxido de zinco. Na seqüência da pesquisa, foram submetidos à análise em microscopia eletrônica de varredura, sendo empregado um aumento de 500X . Cada espécime foi analisado em quatro regiões distintas, procurando-se fazer a avaliação em quatro porções eqüidistantes em todo o contorno da cavidade. O espaço existente entre o material e a cavidade preparada foi medido em $\mu \mathrm{m}$ (micrometros). Os resultados obtidos demonstraram que, nas cavidades preenchidas com Sealer26, não ocorreram fendas, e os maiores espaços material/cavidade ocorreram com o cimento de óxido de zinco e eugenol.

DALÇÓQUIO et al. $^{32}$, em 2001, compararam a quantidade de infiltração de corante em dentes que foram retroobturados com MTA, Ketac-fil, IRM e cianocrilato. Após a apicectomia em 120 caninos humanos extraídos, as cavidades retrógradas foram preparadas com uma profundidade de $3 \mathrm{~mm}$ e suas raízes impermeabilizadas com duas camadas de esmalte para unhas. Em seguida, promoveu-se o preenchimento das cavidades com os materiais mencionados, e logo 
após, imersão das raízes em solução corante de azul de metileno a 1\%. A infiltração foi medida por meio de espectrofotometria após 48 horas, 7 dias e 60 dias. Os resultados mostraram que não houve diferença significante entre os materiais nos períodos de 48 horas e 60 dias, porém no período de 7 dias houve uma diferença significante, sendo que o MTA mostrou os melhores resultados, seguido pelo Ketacfil, cianocrilato e IRM.

SILVA NETO et al. ${ }^{91}$, em 2001, avaliaram a capacidade seladora do MTA e do Super-EBA, quando utilizados em obturações retrógradas. Foram utilizados 36 incisivos centrais superiores humanos extraídos, cujos canais foram preparados biomecanicamente e obturados pela técnica do cone único de gutapercha e cimento de óxido de zinco e eugenol. Após 48 horas, realizou-se a apicectomia removendo-se $3 \mathrm{~mm}$ apicais e a confecção da cavidade retrógrada com aproximadamente $2 \mathrm{~mm}$ de profundidade por meio de pontas ultra-sônicas. Em seguida, realizou-se a impermeabilização da superfície externa das raízes, com uma camada de adesivo Araldite e duas camadas de esmalte para unhas. Após a secagem do agente impermeabilizador (aproximadamente 24 horas) as raízes foram divididas aleatoriamente em três grupos de 10 elementos. As retroobturações propriamente ditas foram, então, realizadas com os seguintes materiais: grupo I ProRoot - MTA; grupo II - MTA - Angelus; grupo III - Super-EBA. Seis dentes foram utilizados como controle (positivo e negativo). As porções coronárias de todos os dentes foram seladas com um material restaurador provisório, e, então, revestidas com um capuz de cera derretida para completar assim , a impermeabilização. Em seguida as raízes foram imersas em solução aquosa de rhodamine B a $0,2 \%$ e mantidas em estufa a $37^{\circ} \mathrm{C}$ por um período de 48 horas. Após esse período as raízes foram lavadas em água corrente por 24horas. Removeu-se a camada de 
impermeabilização e realizou-se o desgaste longitudinal da face mesial radicular expondo-se a retroobturação. Para leitura da magnitude das infiltrações, foi utilizado um microscópio óptico com ocular micrométrica, por meio da técnica da planimetria. Os dados aferidos foram levados para análise estatística, e os resultados mostraram não haver diferença significante entre os grupos.

$\mathrm{KUBO}^{59}$, em 2001, avaliou o selamento de cavidades retrógradas tratadas com diferentes agentes desmineralizantes, e retroobturadas com ProRoot MTA, mediante infiltração marginal por corante. Utilizou sessenta e quatro dentes humanos unirradiculados extraídos, divididos em quatro grupos de 16. Os dentes tiveram seus canais instrumentados, obturados, apicectomizados, e preparados apicalmente por meio de pontas ultra-sônicas. A aplicação dos agentes desmineralizantes foi realizada previamente à retroobturação com ProRoot - MTA. Em cada grupo experimental, dois espécimes foram mantidos como controles internos positivo e negativo para monitorização da infiltração marginal de rhodamine B a $2 \%$ por 24 horas, e dois espécimes foram utilizados para observação em M.E.V. Os grupos experimentais foram divididos em: grupo 1 (nenhuma aplicação de qualquer agente desmineralizante), grupo 2 (aplicação do acido fosfórico $35 \%$ durante 15 segundos), grupo 3 (aplicação de solução de EDTA $17 \%$ pH 7 durante 3 min) e grupo 4 (aplicação de gel de EDTA $24 \% \mathrm{pH} 7$ durante 4 min). Os resultados mostraram que não ocorreram diferenças significativas na infiltração marginal pelo corante entre os grupos 1, 2 e 4 . O grupo 3 apresentou significativamente maior infiltração pelo corante que o grupo 1. A aplicação de agentes desmineralizantes (acido fosfórico e gel de EDTA 24 \%) não promoveu diferenças significativas na infiltração marginal de retroobturações realizadas com ProRoot - MTA. 


\section{PROPOSIÇÃO}

A revisão de literatura confirmou ser oportuna e viável a proposta de trabalho vislumbrada na introdução desta pesquisa. Assim, nos propomos a:

1 - Avaliar in vitro a capacidade seladora, por meio da infiltração marginal de corante, de alguns materiais utilizados em perfurações de furca de molares humanos;

2 - Observar a influência da utilização de uma matriz de gesso Paris (sulfato de cálcio), em relação a infiltração marginal e a prevenção de extravasamento dos materiais;

3 - Verificar, sob microscopia eletrônica de varredura, a adaptação marginal destes materiais junto à s paredes dentinárias da perfuração;

4 - Estabelecer uma possível relação entre a infiltração e a adaptação marginal dos materiais utilizados. 
4 M A TERIAL E MÉTO DOS 


\section{MATERIAL E MÉTODOS}

\subsection{Avaliação da capacidade seladora por infiltração de corante}

Foram utilizados 88 dentes molares humanos extraídos superiores ou inferiores, e mantidos em solução aquosa de formol $10 \%$ até o momento da utilização. Esses dentes foram obtidos do banco de dentes da disciplina de Endodontia da Faculdade de Odontologia de Bauru, da Universidade de São Paulo. Os dentes foram seccionados transversalmente por meio de discos de carburundum, tendo as coroas removidas em um nível logo acima do assoalho da câmara pulpar, e as raízes, logo abaixo da região de furca, de maneira que o segmento relacionado com o assoalho da câmara pulpar permanecesse intacto.

Em seguida, realizou-se a impermeabilização de toda a superfície externa dos espécimes, com uma camada de adesivo Araldite* de presa lenta , na proporção de 1:1, e após 24 horas, foi reforçada com duas camadas de esmalte para unhas**. Procurou-se simular as condições clínicas, incluindo-se os espécimes em uma base de silicona pesada ${ }^{* * *}$, de tal maneira que possibilitasse sua recolocação sobre a mesma sempre na mesma posição, obtendo-se, assim, alvéolos artificiais particularizados (Figura 1), possibilitando uma uniformidade durante 0 preenchimento das perfurações, e limitando a movimentação dos espécimes.

Perpendicularmente, no centro do assoalho de cada espécime, foi realizada uma perfuração utilizando-se de uma broca esférica $n^{\circ} 2^{\star \star \star \star}$, em alta rotação. A seguir, essa perfuração foi ampliada com broca Gates-Glidden $n^{\circ} 5^{\star \star \star \star}$,

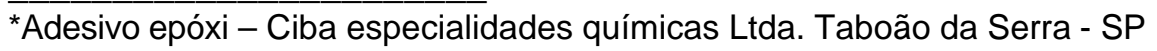

${ }^{* \star}$ Colorama Ceil - Coml. Exp. Ind. Ltda. - São Paulo - SP

${ }^{* * *}$ Optosil Comfort e activator universal - Heraeus Kulzer GMbH\&Co.KG - Germany

${ }^{* * * *}$ Dentsply - Maillefer, Swiss
} 
obtendo-se assim uma perfuração com 1,4 mm em diâmetro. A irrigação foi feita com hipoclorito de sódio a $1 \%$ * durante a perfuração com a broca esférica, alargamento com a broca Gates-Glidden e ao final, com soro fisiológico.

Buscando-se conferir a maior homogeneização possível aos grupos, as espessuras dos assoalhos das câmaras pulpares dos 88 espécimes, foram medidas utilizando-se de um paquímetro, e, então, os grupos foram formados. Cada grupo foi dividido em 2 subgrupos de 10 elementos cada, sendo que um grupo recebeu a aplicação de uma matriz de gesso Paris** no fundo da perfuração, e o outro não, conforme mostra a Tabela 1.

Tabela 1 - Distribuição dos espécimes e identificação dos grupos em função dos materiais utilizados

\begin{tabular}{|c|c|c|}
\hline Grupos & Cimentos & $n^{\circ}$ de espécimes \\
\hline \multirow[b]{2}{*}{1} & ProRoot - MTA & 10 \\
\hline & $\begin{array}{c}\text { ProRoot - MTA + matriz } \\
\text { de gesso Paris }\end{array}$ & 10 \\
\hline \multirow[b]{2}{*}{2} & MTA - Angelus & 10 \\
\hline & $\begin{array}{c}\text { MTA - Angelus + matriz } \\
\text { de gesso Paris }\end{array}$ & 10 \\
\hline \multirow[b]{2}{*}{3} & Super-EBA & 10 \\
\hline & $\begin{array}{c}\text { Super-EBA + matriz de } \\
\text { gesso Paris }\end{array}$ & 10 \\
\hline \multirow[b]{2}{*}{4} & MBP-c & 10 \\
\hline & $\begin{array}{c}\text { MBP-c + matriz de gesso } \\
\text { Paris }\end{array}$ & 10 \\
\hline controle positivo & - & 4 \\
\hline controle negativo & - & 4 \\
\hline \multicolumn{2}{|c|}{ TOTAL } & 88 \\
\hline
\end{tabular}

Para a obturação das perfurações os materiais foram proporcionados e manipulados seguindo as recomendações dos fabricantes ou dos idealizadores. 


\section{Obturação das perfurações}

Antes do preenchimento das perfurações com os materiais seladores, criou-se na base de silicona pesada (alvéolo artificial) frontalmente à perfuração uma depressão onde foi posicionada passivamente, imediatamente antes da obturação, bolinhas de algodão padronizadas* umedecidas com água destilada, simulando as condições clínicas quanto ao aspecto de umidade e resistência à compressão dos tecidos de suporte.

Para a confecção da matriz, misturou-se partes iguais de gesso Paris e água destilada. A pasta formada foi inserida no interior da perfuração por meio de um porta-amálgama cirúrgico, e, então, compactada passivamente com um condensador de amálgama $n^{\circ} 1^{* *}$. Após 15 minutos da presa inicial, a porção mais coronal do gesso foi removida da perfuração com a ajuda de uma cureta endodôntica e uma lima Kerr $n^{\circ} 110^{\star \star *}$ aparada perpendicularmente ao longo eixo, de modo que atuasse adaptada, ajustando-se às paredes da cavidade da perfuração, deixando uma matriz de gesso atapetando o fundo da perfuração com uma espessura de aproximadamente $0,5 \mathrm{~mm}$. Assim, com as matrizes confeccionadas e os espécimes assentados nos alvéolos artificiais realizou-se a obturação das perfurações.

O material foi colocado na perfuração com auxílio de um porta amálgama cirúrgico e assentado ou condensado com um condensador de amálgama $n^{\circ} 1$ (Figura 2), de acordo com as orientações clínicas do fabricante do mesmo. A superfície da obturação, no interior da câmara pulpar foi nivelada com a superfície do assoalho, procurando-se alisá-la, o máximo, com a utilização de

\footnotetext{
${ }^{*}$ Roeko size $00-$ Germany

${ }^{* *}$ SS White artigos dentários Ltda. Juiz de Fora - MG Brasil

${ }^{* \star *}$ Dentsply - Maillefer, Swiss
} 
brunidores para amálgama. Sobre o assoalho da câmara pulpar foi assentado uma camada de Cimpat $^{\star}$ e sobre esta foi colocado um duplo capuz de cera $n^{\circ} 7$ derretida, complementando-se, assim, a impermeabilização dos espécimes.

Oito espécimes formaram os grupos controle e não tiveram as perfurações obturadas. Utilizou-se 4 controles negativos, com impermeabilização completa de toda superfície externa da região de furca, inclusive, para comprovar a qualidade da impermeabilização e 4 controles positivo, sem obturação da perfuração, para a comprovação da eficácia do método utilizado para a penetração do corante.

Imediatamente após esses procedimentos, os espécimes de cada grupo foram colocados em recipientes plásticos distintos e identificados, e, então, imersos em solução aquosa corante de rhodamine $B^{\star *}$ a $0,2 \%$, com $p H 7,0$, e mantidos em estufa a $37^{\circ} \mathrm{C} \pm 1$ por um período de 48 horas. Essa solução foi preparada com solução tampão de fosfato, tamponada em pH 7,0.

Após esse período todos os elementos foram retirados da solução corante e lavados em água corrente por 12 horas. Removeu-se a camada de impermeabilização com auxílio de uma espátula LeCron e procedeu-se à escovação e lavagem dos espécimes sob água corrente.

Completada esta fase, procedeu-se às manobras de preparo dos espécimes para a verificação da infiltração linear ocorrida ao longo das paredes das perfurações. Com um disco diamantado***, os espécimes foram seccionados longitudinalmente no sentido mesio-distal, em direção ápico-cervical.

${ }^{*}$ Cimpat blanc cimento provisório - Septodont, Saint-Maur, France

**Departamento de Bioquímica da FOB - USP Bauru - SP Brasil

${ }^{* \star *}$ Disco diamantado Dulpla face - KG Sorensen ind. e com. Ltda Barueri -SP Brasil 
A seguir, cada uma das amostras seccionadas, foi fixada em uma lâmina de vidro e levada a um microscópio óptico* comum munido de objetiva com aumento de $4 \mathrm{X}$ e de uma ocular micrométrica** para a análise da infiltração ocorrida. Considerou-se como medida da infiltração o comprimento do traço de corante de maior extensão que seguia na interface obturação-dentina, desde a porção mais apical do material obturador até sua porção mais cervical (Figuras 3 a 10).

A análise da capacidade seladora proporcionada pelos materiais obturadores, a partir da furca dos segmentos dentários foi realizada utilizando-se de escores numéricos - 0, 1, 2 e 3;

0 - não houve infiltração;

1 - infiltração ocorreu até o primeiro terço do trajeto da perfuração;

2 - infiltração até o segundo terço do trajeto da perfuração;

3 - infiltração de todo o trajeto da perfuração.

Nos espécimes onde foi utilizado a matriz de gesso Paris a análise da infiltração marginal foi efetuada apenas no trajeto do material obturador/perfuração, descartando-se o trajeto obturado pela matriz.

Três observadores participaram dessa leitura, atuando independentemente um do outro.

Os resultados foram tabulados e submetidos ao teste estatístico de Mann-Whitey para verificação da infiltração marginal dos cimentos em função da presença da matriz de gesso Paris, ao teste de Kruskal-Wallis para determinação de possíveis diferenças entre os materiais testados e ao teste de Dunn para comparação entre grupos.

\footnotetext{
*Bausch \& Lomb USA

${ }^{* *}$ Carl Zeiss 5+100/100mm -Germany
} 


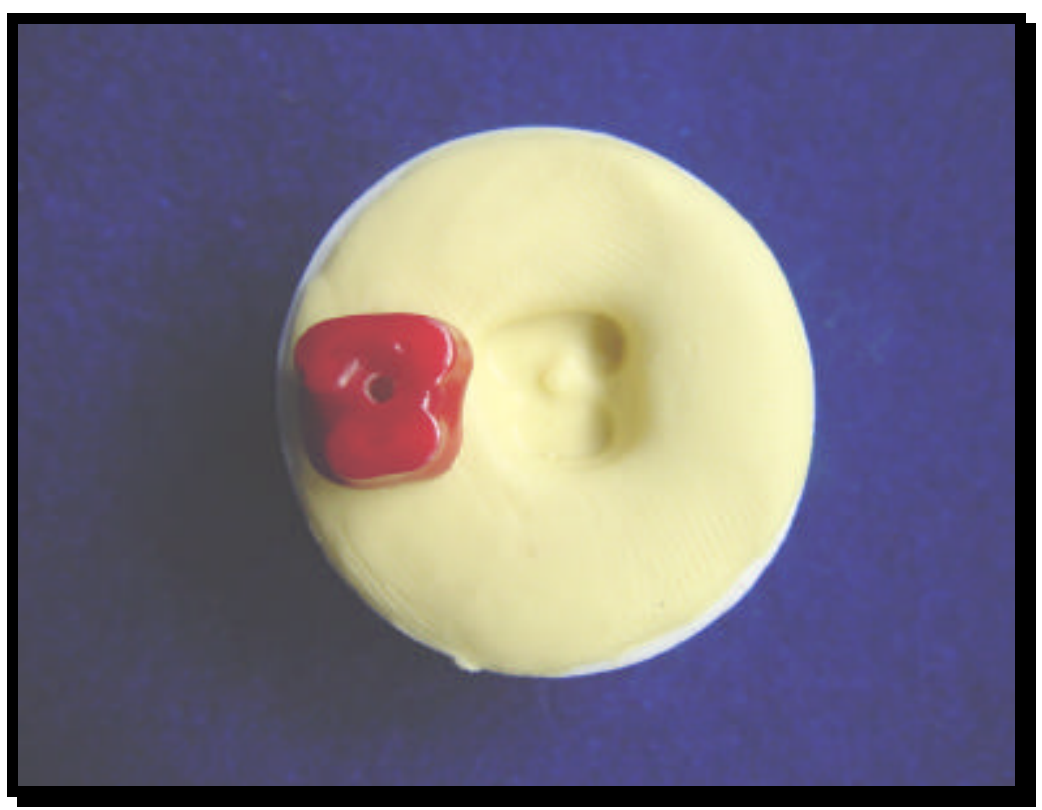

Figura 1 - Espécime perfurado após impermeabilização e confecção do alvéolo artificial em silicona pesada

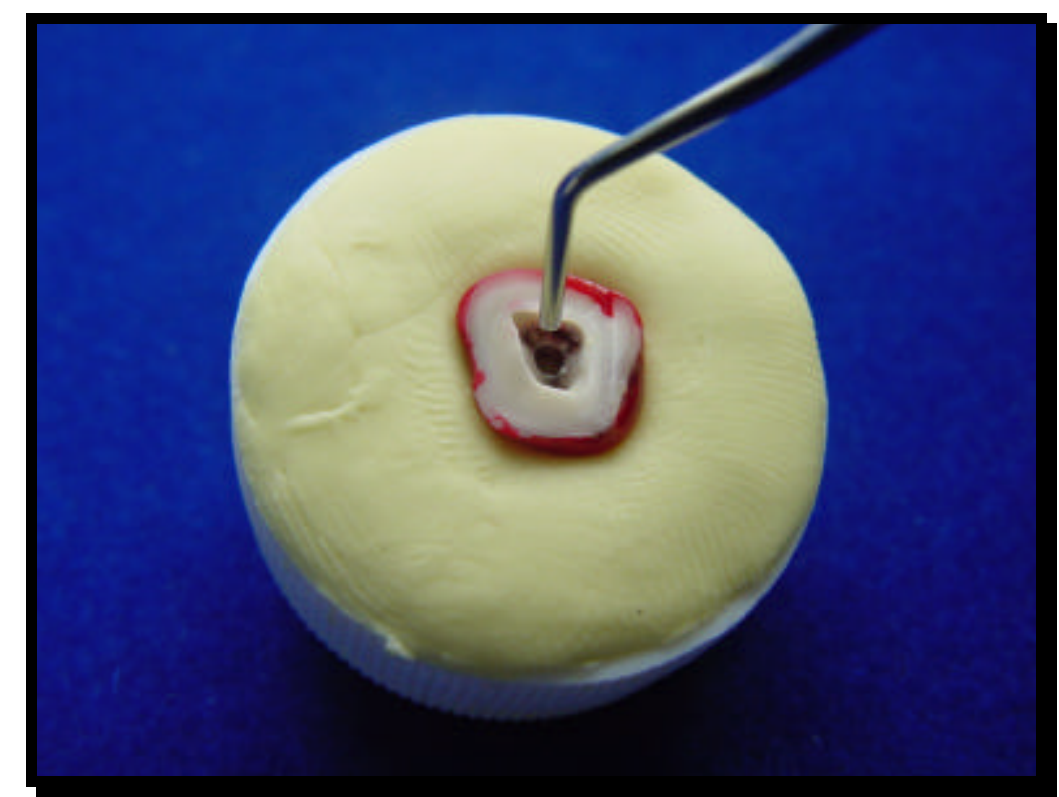

Figura 2 - Espécime em posição de trabalho evidenciando a condensação dos materiais na cavidade da perfuração 


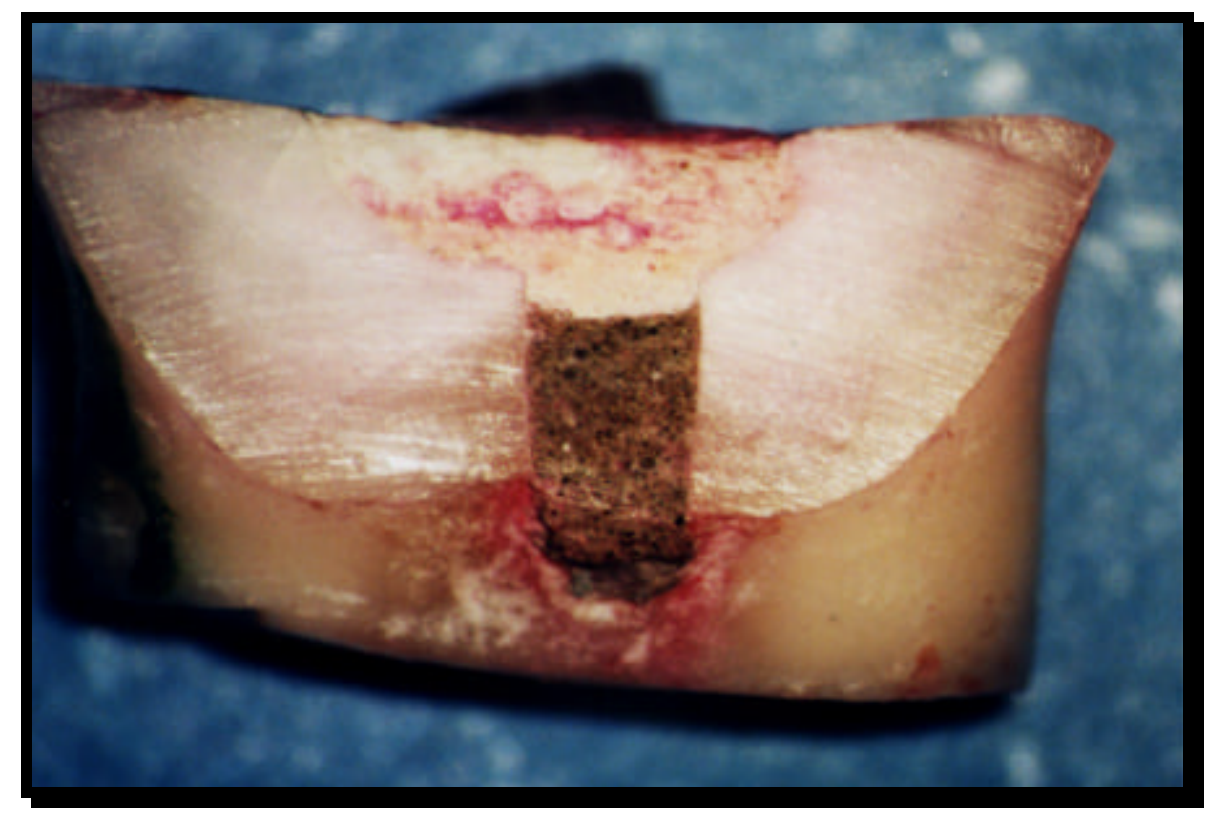

Figura 3 - Hemisecção do espécime obturado com cimento MTA - Angelus, após imersão em rhodamine B

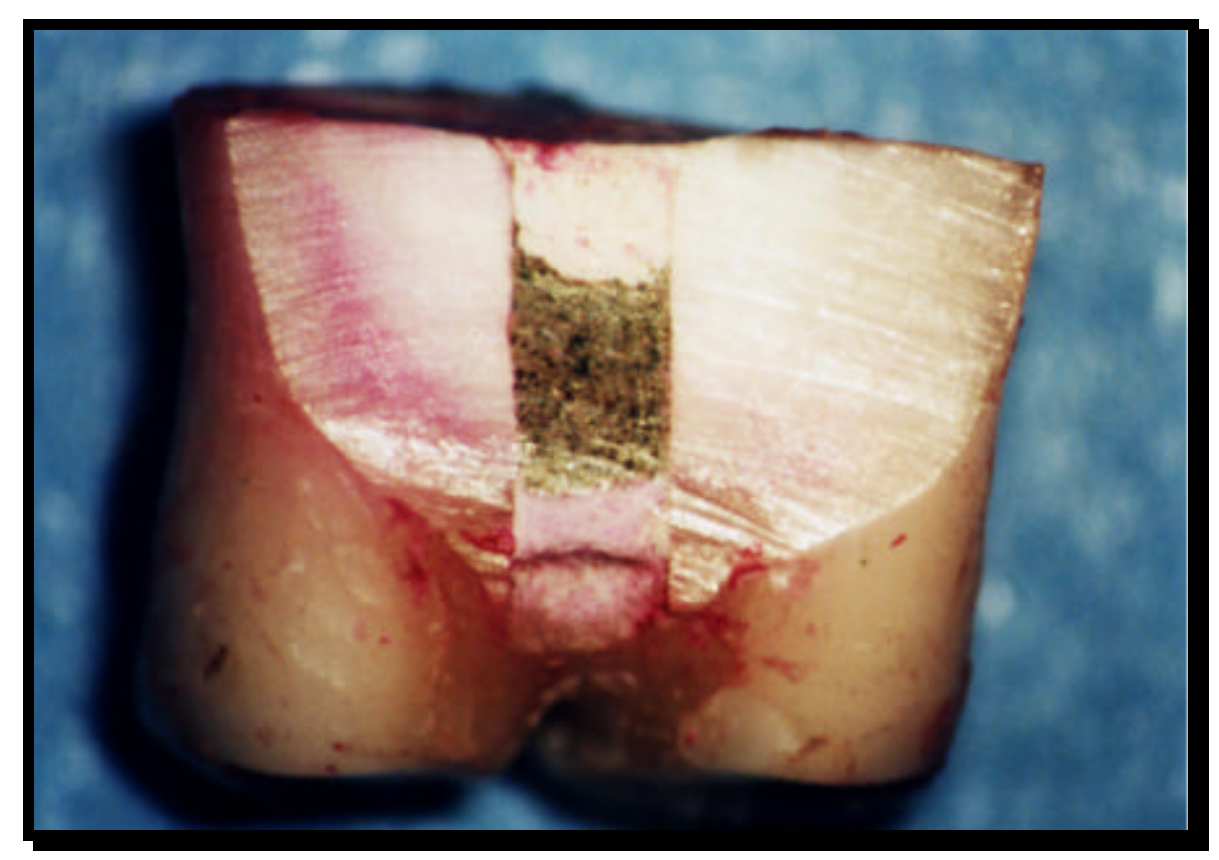

Figura 4 - Hemisecção do espécime obturado com cimento MTA - Angelus na presença da matriz de gesso Paris, após imersão em rhodamine $B$ 


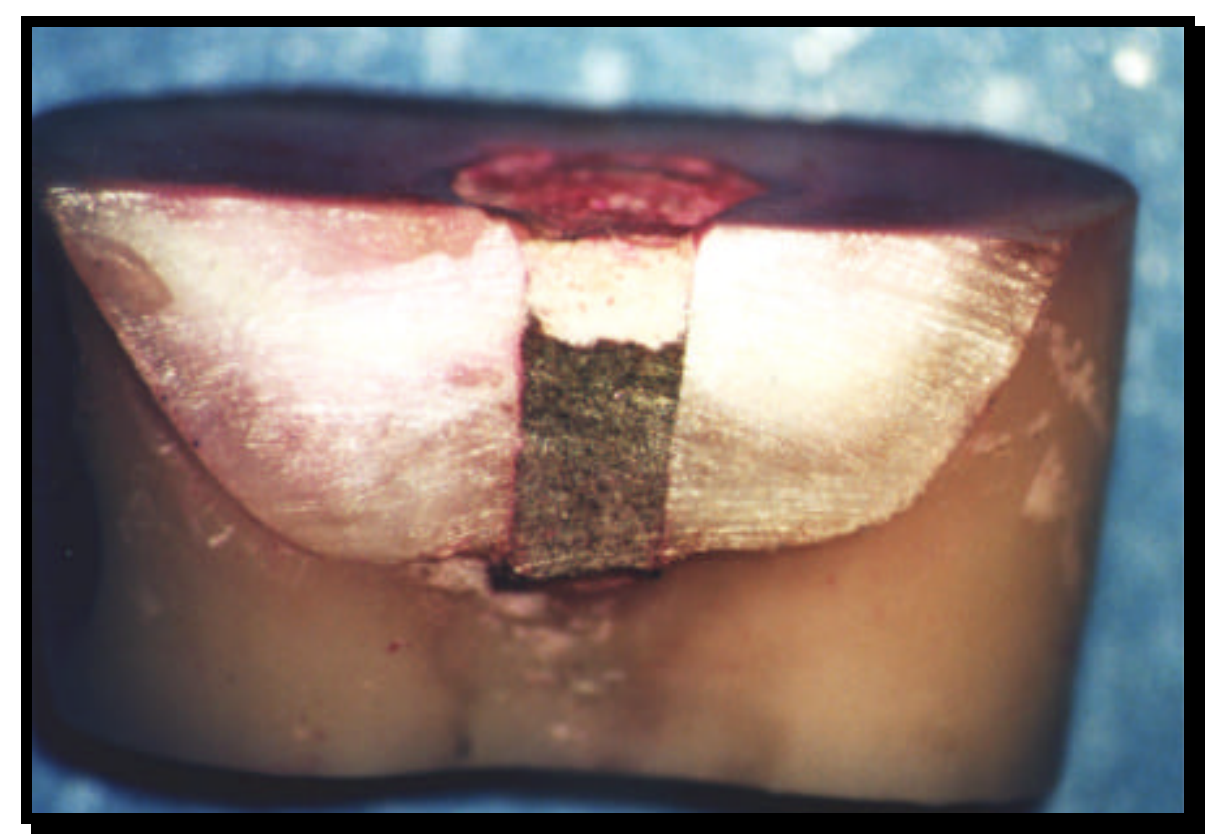

Figura 5 - Hemisecção do espécime obturado com cimento ProRoot - MTA, após imersão em rhodamine $B$

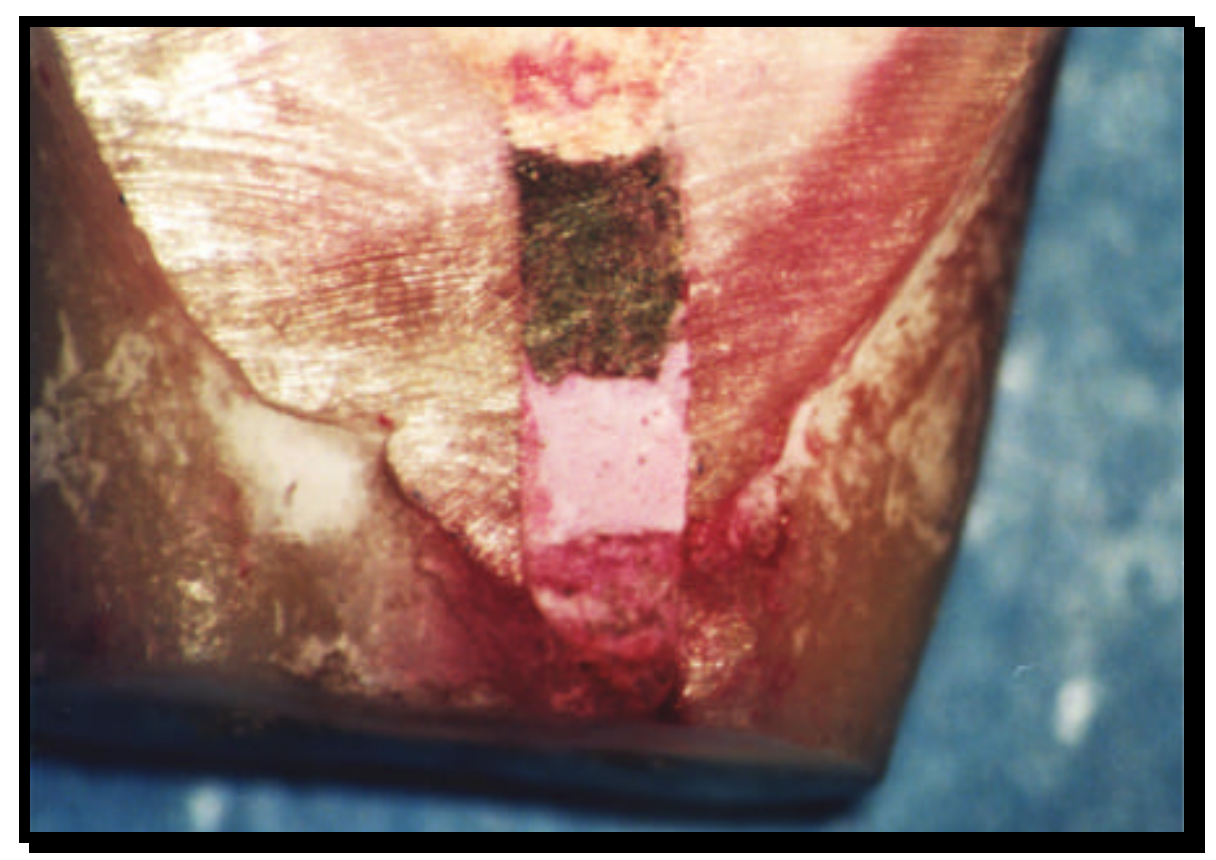

Figura 6 - Hemisecção do espécime obturado com cimento ProRoot - MTA na presença da matriz de gesso Paris, após imersão em rhodamine $B$ 


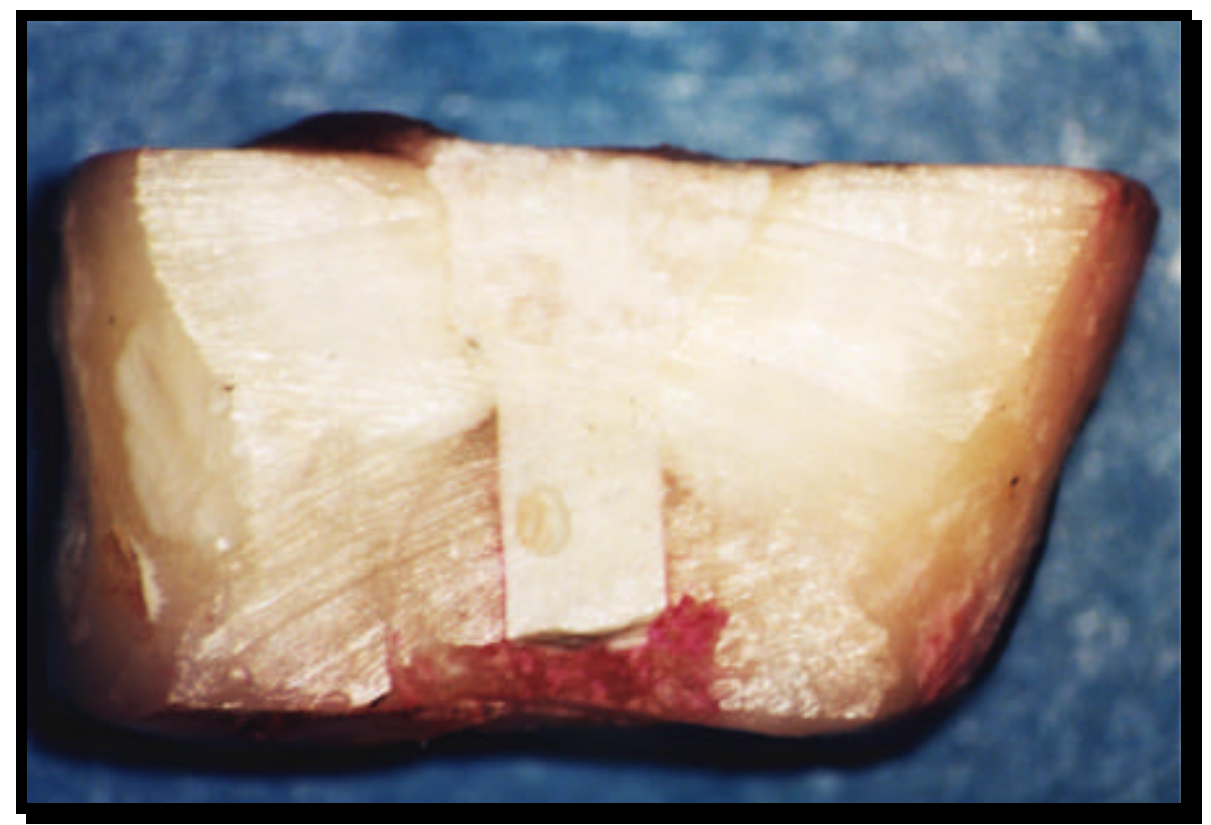

Figura 7 - Hemisecção do espécime obturado com cimento Super-EBA, após imersão em rhodamine $B$

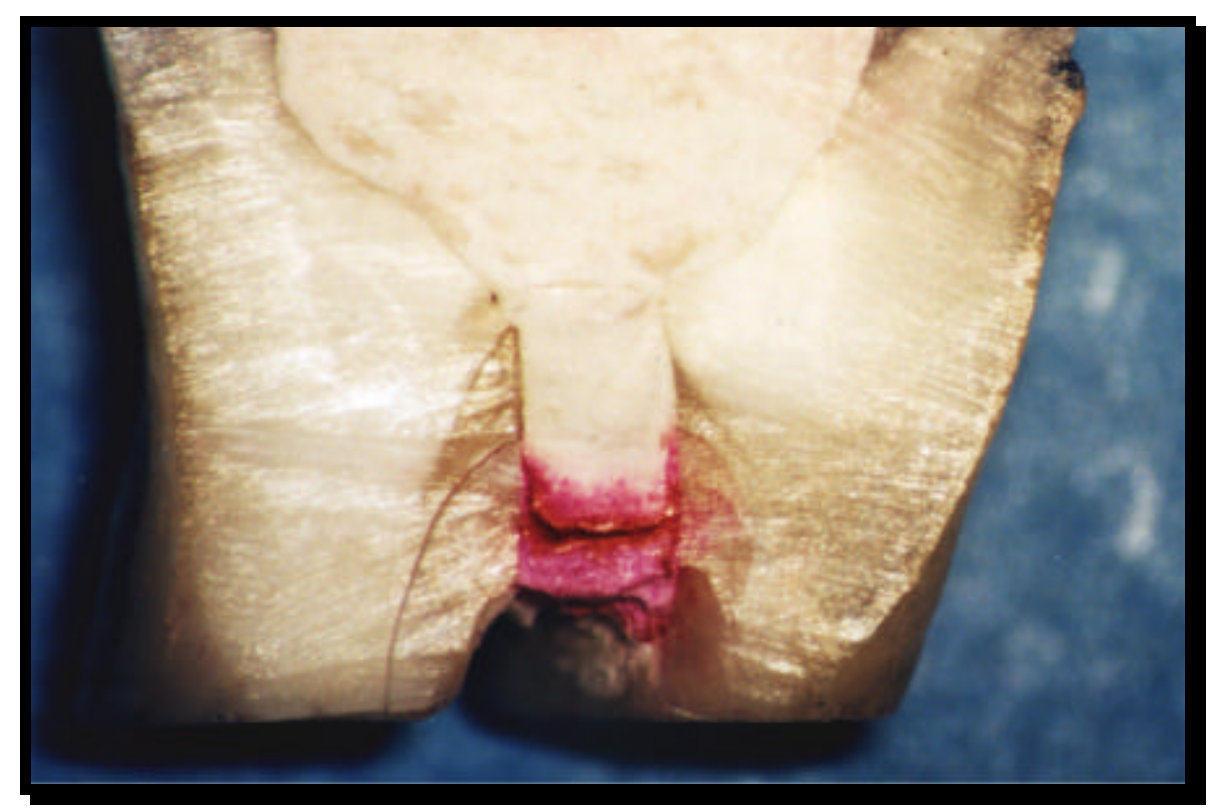

Figura 8 - Hemisecção do espécime obturado com cimento Super-EBA na presença da matriz de gesso Paris, após imersão em rhodamine $B$ 


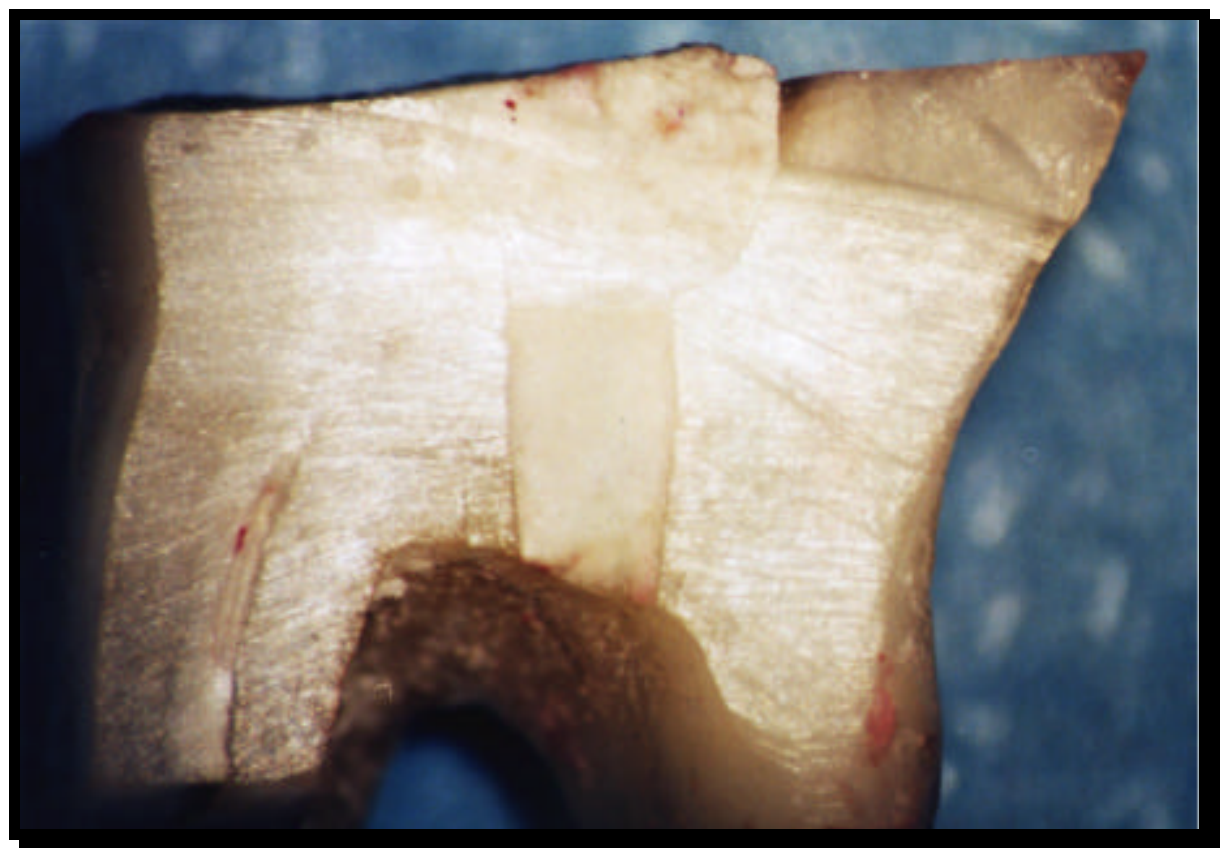

Figura 9 - Hemisecção do espécime obturado com cimento MBP-c, após imersão em rhodamine $B$

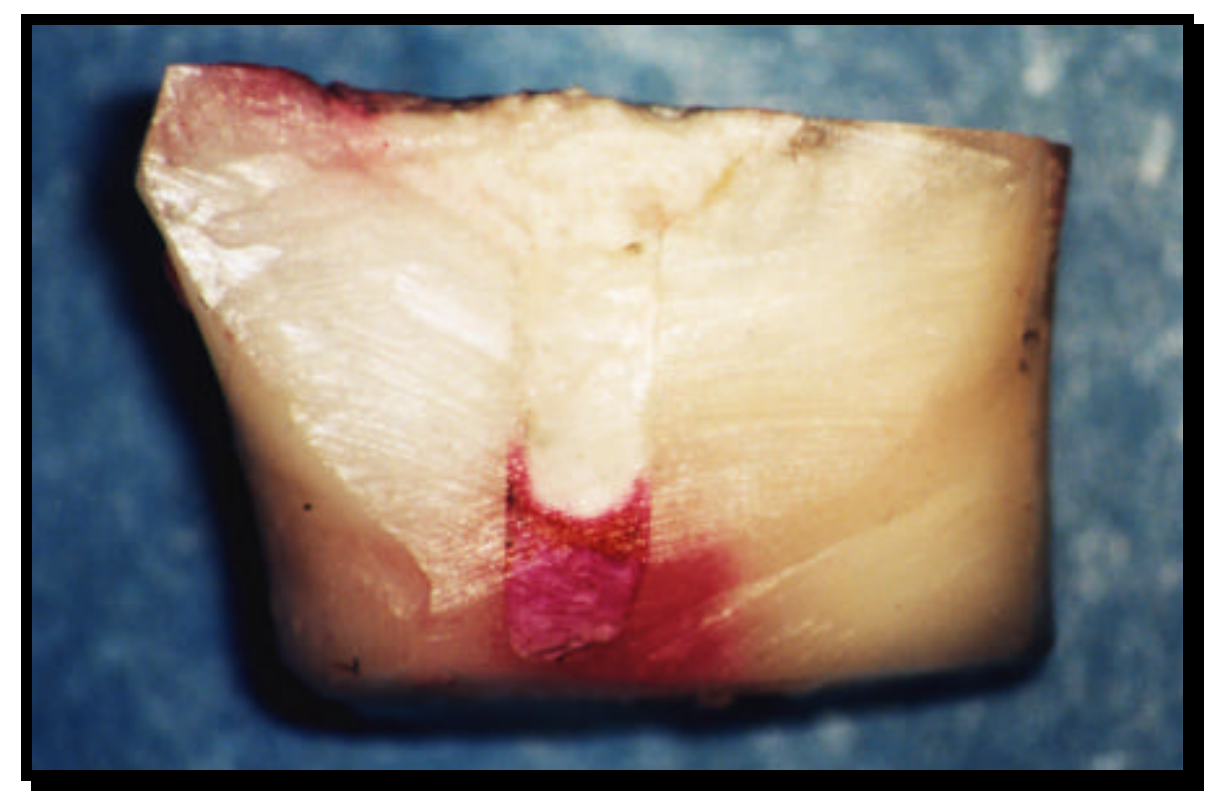

Figura 10 - Hemisecção do espécime obturado com cimento MBP-c na presença da matriz de gesso Paris, após imersão em rhodamine $B$ 


\subsection{Preparo dos espécimes para microscopia eletrônica de varredura}

\subsubsection{Manobras prévias e montagem}

Para realização do teste de adaptação marginal dos materiais obturadores, em relação às paredes dentinárias, foram selecionados 16 dentes molares humanos extraídos superiores ou inferiores, que foram submetidos à mesma metodologia descrita anteriormente, exceto os passos de impermeabilização da superfície externa e imersão na solução corante que não foram executados, nesta fase.

Para a realização da obturação das perfurações, cada grupo foi dividido em 2 subgrupos de 2 elementos cada, sendo que um grupo recebeu uma matriz de gesso Paris, e o outro não, conforme mostra a Tabela 2, seguindo-se, então, a obturação das perfurações de maneira idêntica e com os materiais já descritos, anteriormente. 
Tabela 2 - Distribuição dos espécimes e identificação dos grupos em função dos materiais utilizados

\begin{tabular}{|c|c|c|}
\hline Grupos & Cimentos & $n^{\circ}$ de espécimes \\
\hline \multirow[b]{2}{*}{1} & ProRoot - MTA & 2 \\
\hline & $\begin{array}{c}\text { ProRoot - MTA + matriz } \\
\text { de gesso Paris }\end{array}$ & 2 \\
\hline \multirow[b]{2}{*}{2} & MTA - Angelus & 2 \\
\hline & $\begin{array}{c}\text { MTA - Angelus + matriz } \\
\text { de gesso Paris }\end{array}$ & 2 \\
\hline \multirow[b]{2}{*}{3} & Super-EBA & 2 \\
\hline & $\begin{array}{c}\text { Super-EBA + matriz de } \\
\text { gesso Paris }\end{array}$ & 2 \\
\hline \multirow[b]{2}{*}{4} & MBP-c & 2 \\
\hline & $\begin{array}{c}\text { MBP-c + matriz de gesso } \\
\text { Paris }\end{array}$ & 2 \\
\hline \multicolumn{2}{|c|}{ TOTAL } & 16 \\
\hline
\end{tabular}

A seguir os espécimes foram desgastados com auxílio de um disco diamantado, reduzindo suas dimensões, preservando-se apenas a região portadora da obturação da perfuração e suas circunjascências. As amostras foram secas com jatos de ar procurando eliminar possíveis resíduos dentários remanescentes ao corte, sobre os materiais avaliados.

Em seguida, foram fixadas com esmalte para unhas em uma base cilíndrica de metal ("stub"), com $1 \mathrm{~cm}$ de altura e $0,9 \mathrm{~mm}$ de diâmetro, de modo que a região da furca ficasse voltada para o observador. (Figura 11 ) 


\subsubsection{Metalização}

O conjunto foi levado ao aparelho metalizador HUMMER VII, o qual recobriu os espécimes com uma camada de ouro de $20 \mathrm{~nm}$ de espessura (Figura 11).

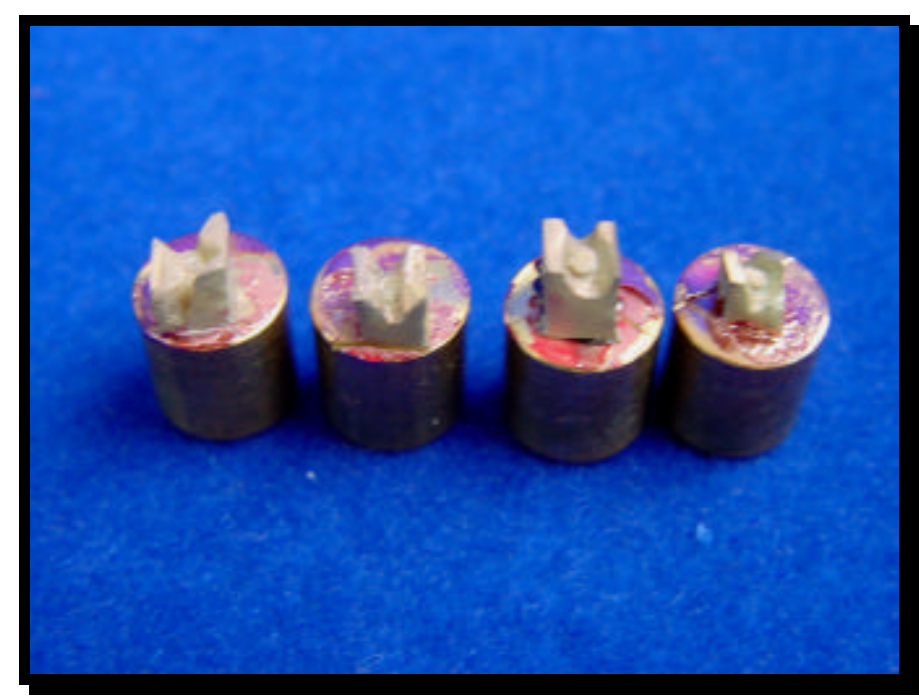

Figura 11 - Espécimes montados em "stubs" e metalizados para M.E.V.

\subsection{Fotomicrografias em microscopia eletrônica de varredura e análise da adaptação do material às paredes dentinárias}

Os espécimes idealmente preparados foram levados ao microscópio eletrônico de varredura, modelo JEOL JSM-T220 A, operando com $15 \mathrm{KV}$, para a realização de fotomicrografias que foram obtidas com uma máquina fotográfica MAMUYA 50A - MRH, acoplada ao microscópio eletrônico, utilizando filme Neopan 100 ACROS preto e branco (Figura 12), obtendo-se fotomicrografias com aumento de 50X e 200X; conseguindo-se uma visão panorâmica da adaptação do material obturador às paredes dentinárias com o pequeno aumento (50X). Já as fotomicrografias com aumento de 200X foram realizadas em locais onde foram 
observados espaços ou fendas entre a parede dentinária da perfuração e o material obturador.

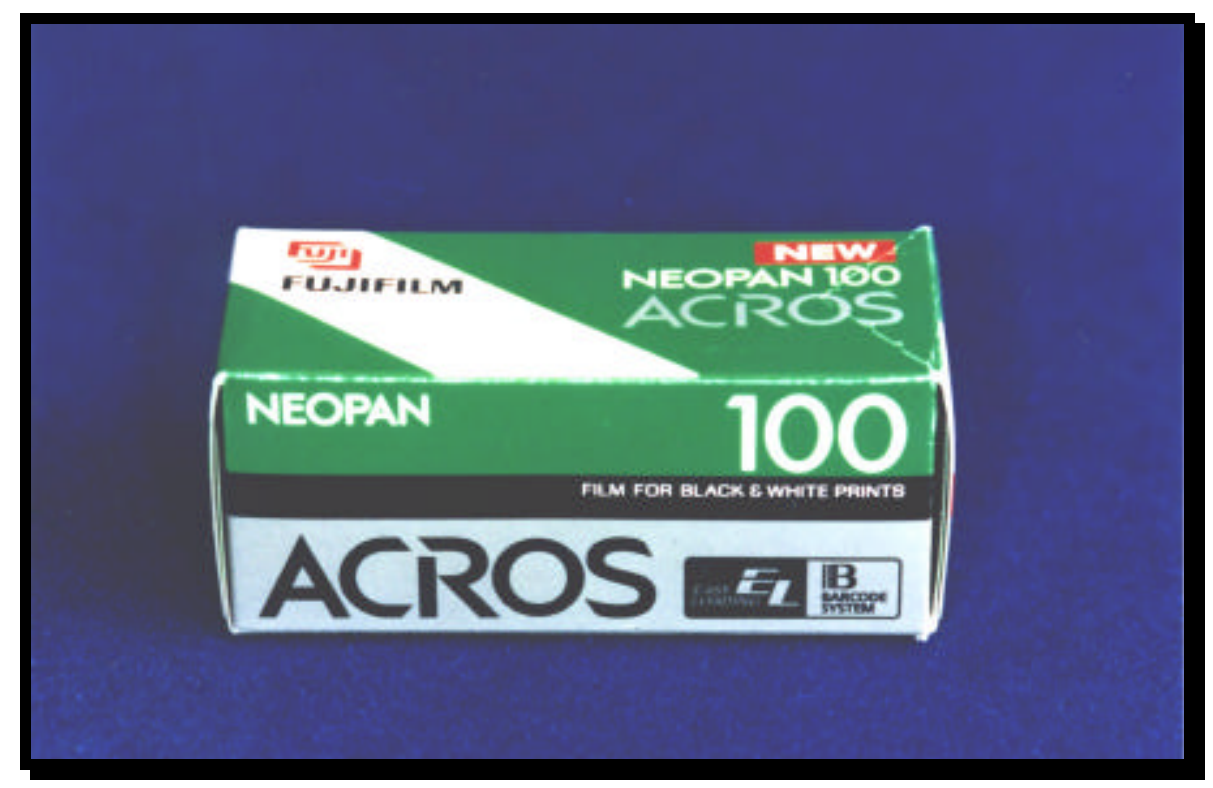

Figura 12 - Filme Neopan 100 ACROS preto e branco

Desta forma, a M.E.V. mostrou a visão em relevo da adaptação marginal proporcionada pelos materiais utilizados. (Figuras 13 a 17) 


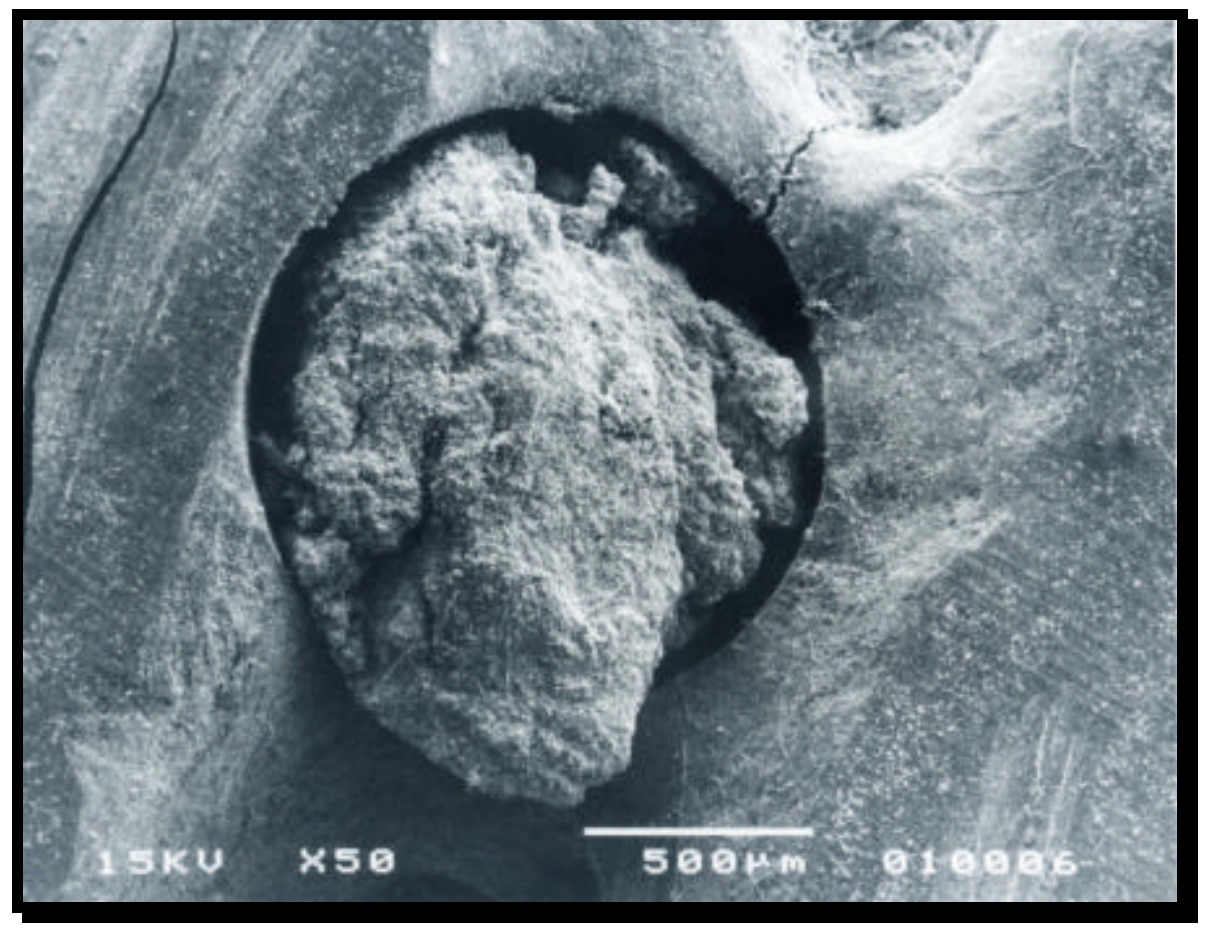

A

(aumento original $=50 \mathrm{X}$ )

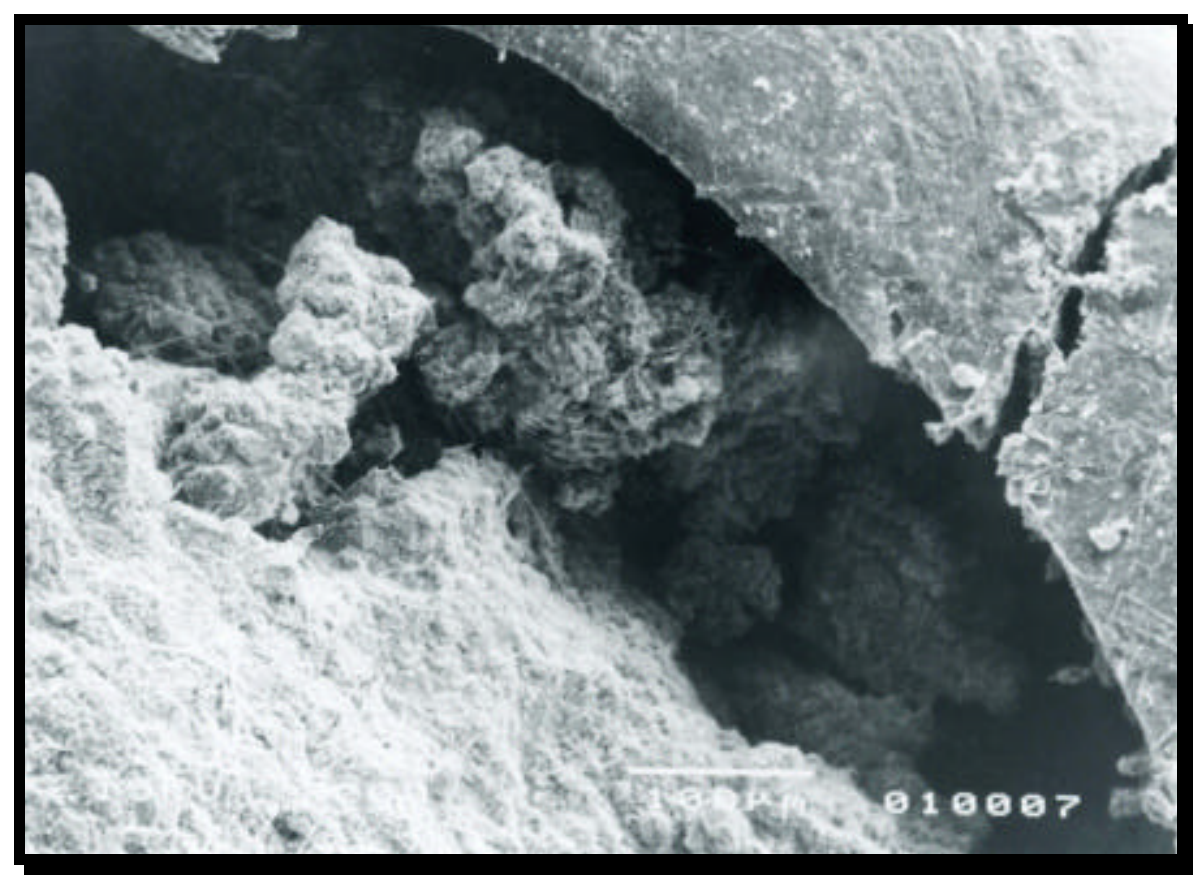

B

(aumento original $=200 \mathrm{X}$ )

Figura 13 (A e B) - Fotomicrografias da adaptação marginal do cimento MTA Angelus às paredes dentinárias da perfuração 


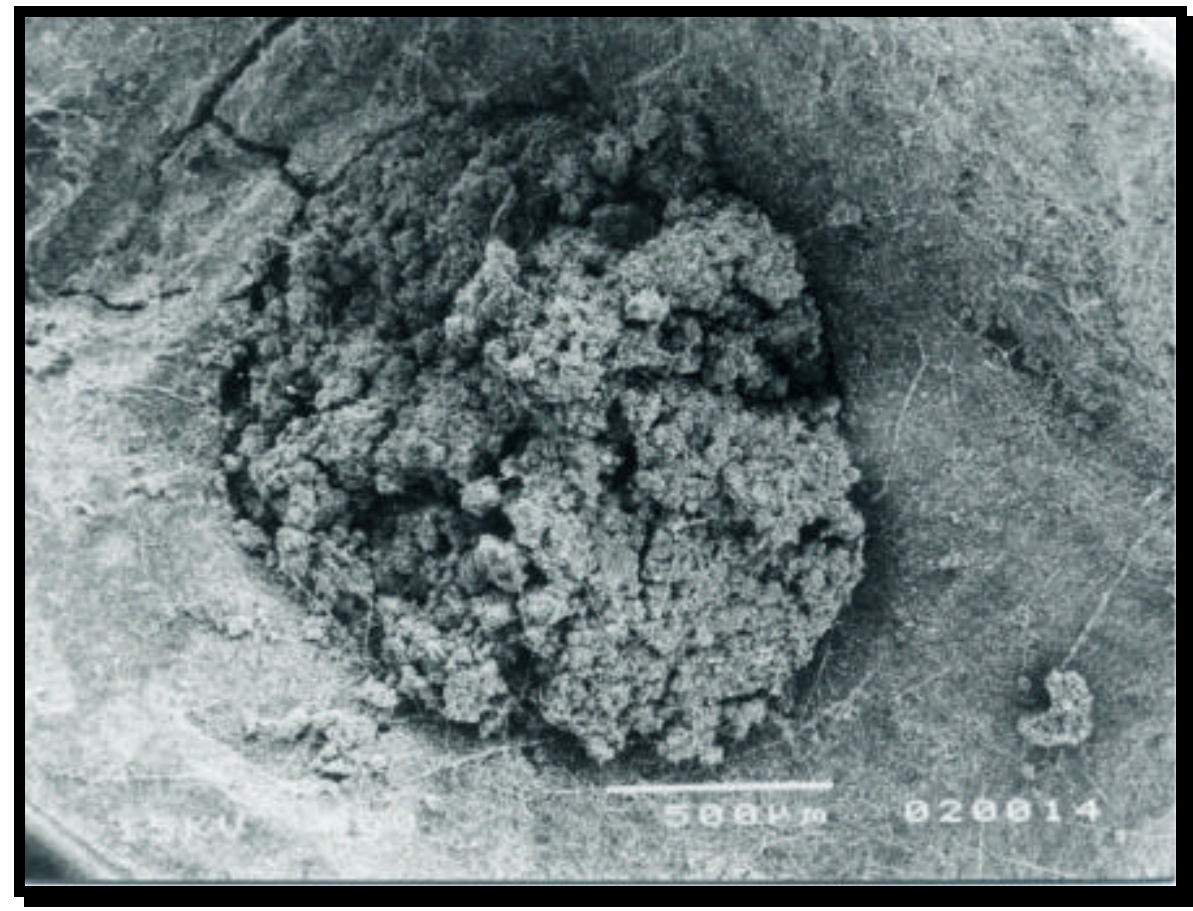

A

(aumento original $=50 \mathrm{X}$ )

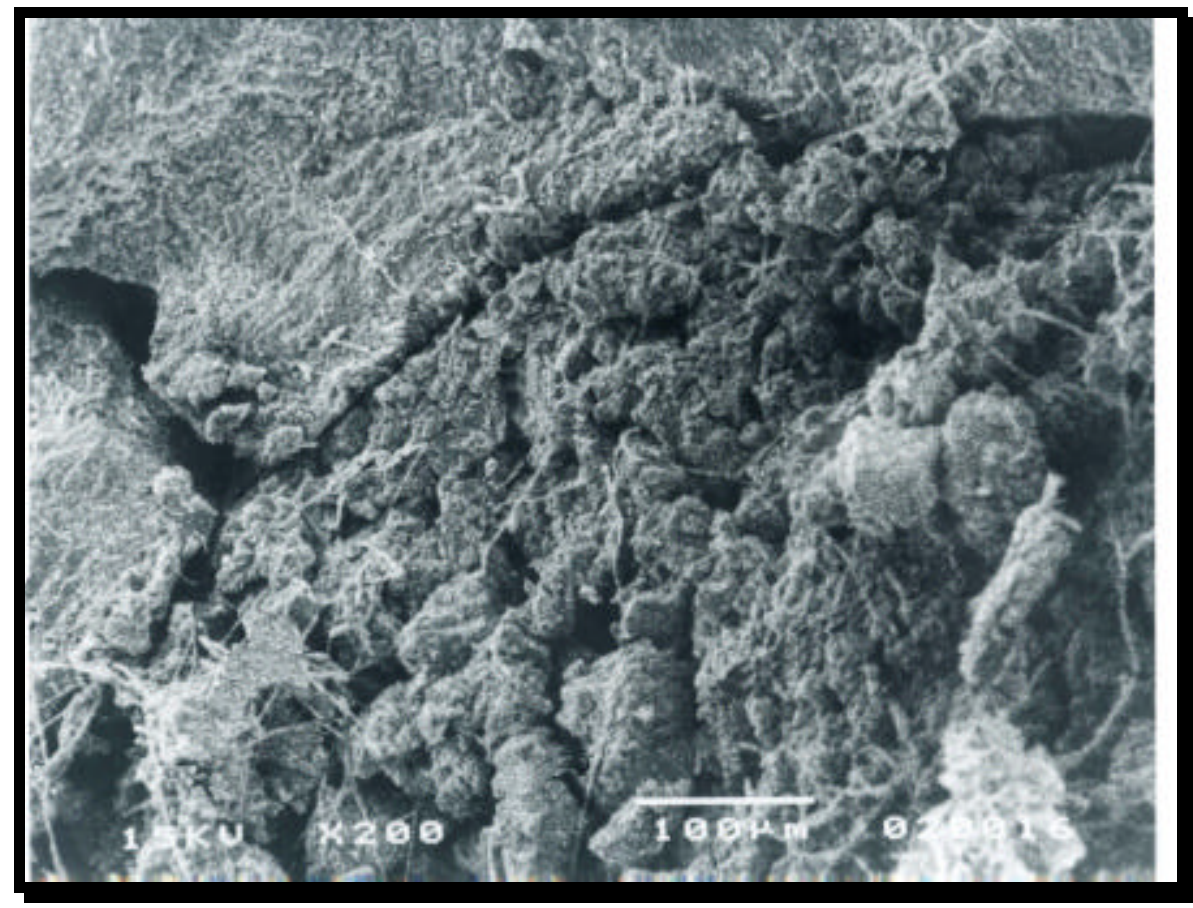

B

(aumento original $=200 \mathrm{X}$ )

Figura 14 (A e B) - Fotomicrografias da adaptação marginal do ProRoot - MTA às paredes dentinárias da perfuração 


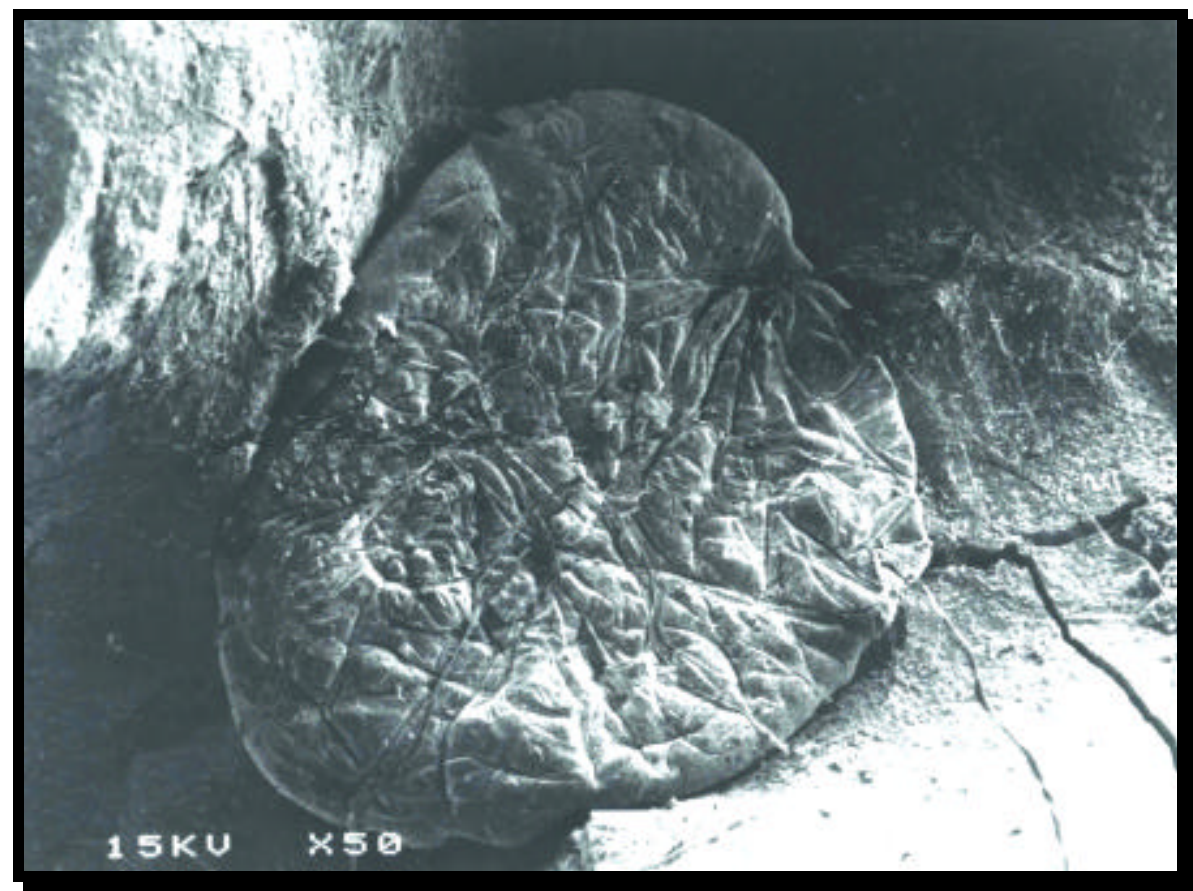

A

(aumento original $=50 \mathrm{X}$ )

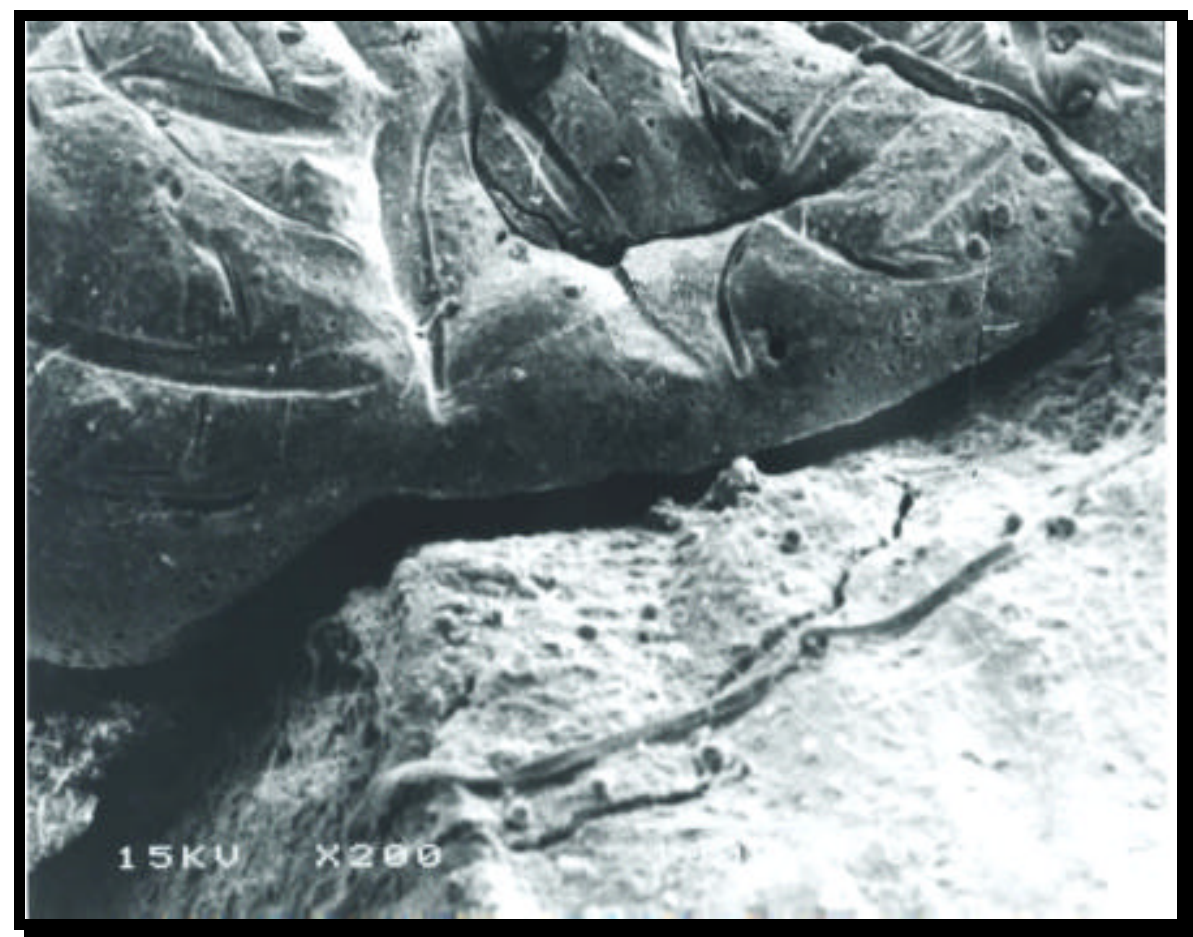

B

(aumento original $=200 X)$

Figura 15 (A e B) - Fotomicrografias da adaptação marginal do Super-EBA às paredes dentinárias da perfuração 


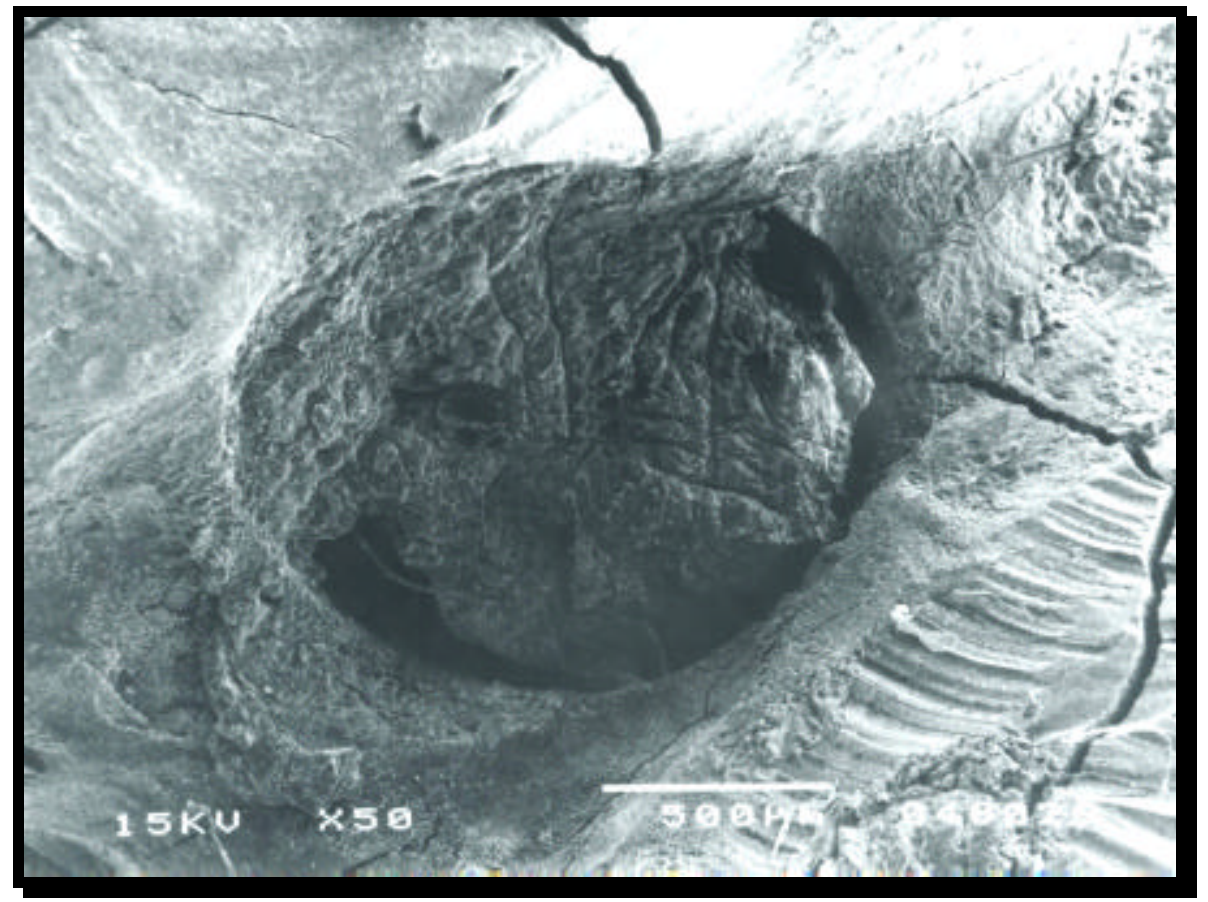

A

(aumento original $=50 \mathrm{X}$ )

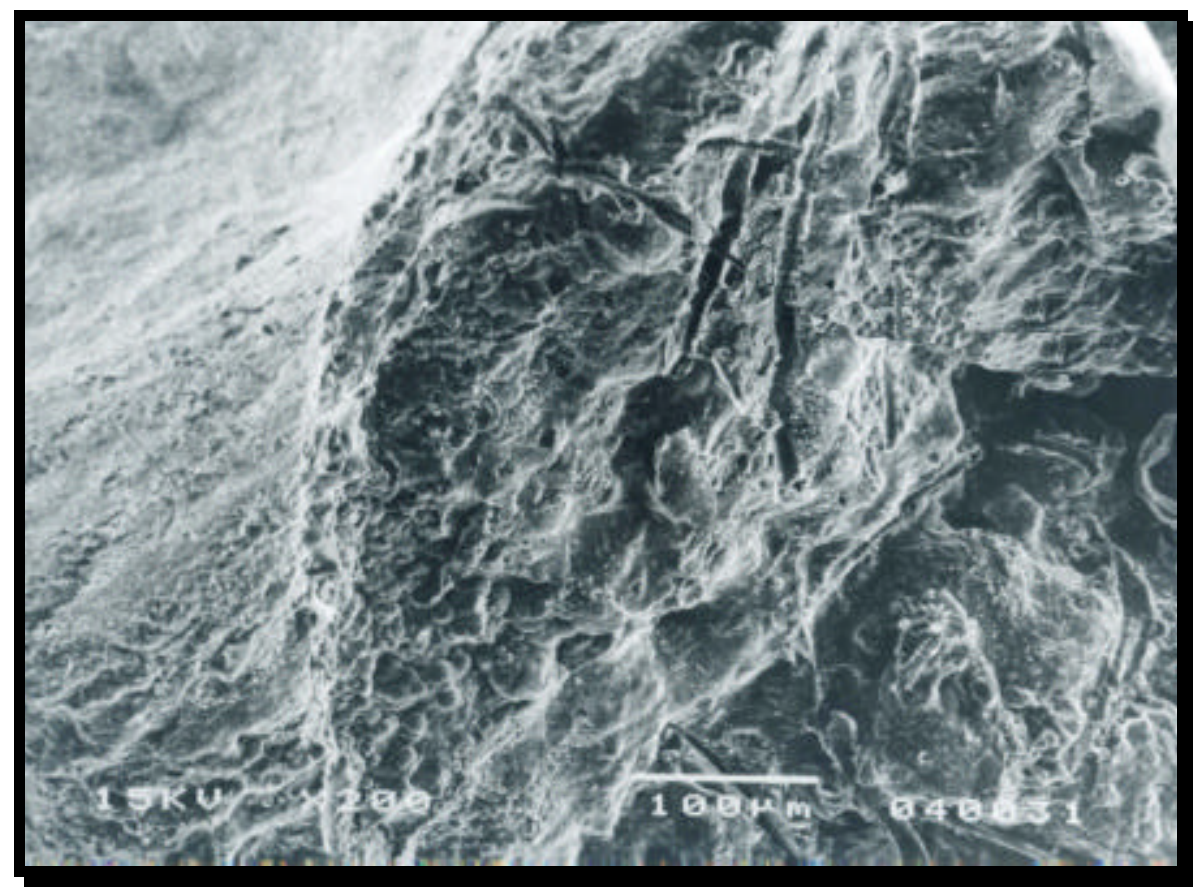

B

(aumento original $=200 X)$

Figura 16 (A e B) - Fotomicrografias da adaptação marginal do cimento MBP-c às paredes dentinárias da perfuração 


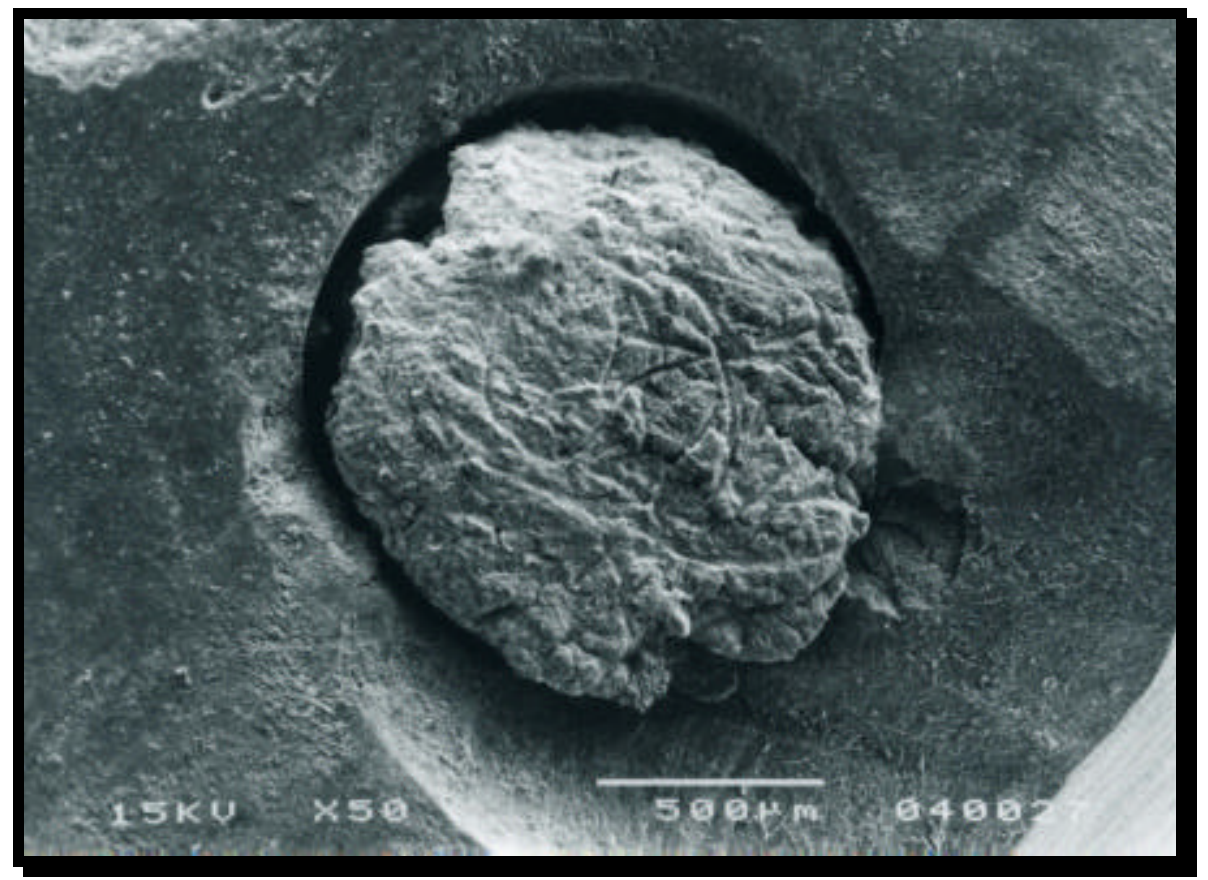

A

(aumento original $=50 \mathrm{X}$ )

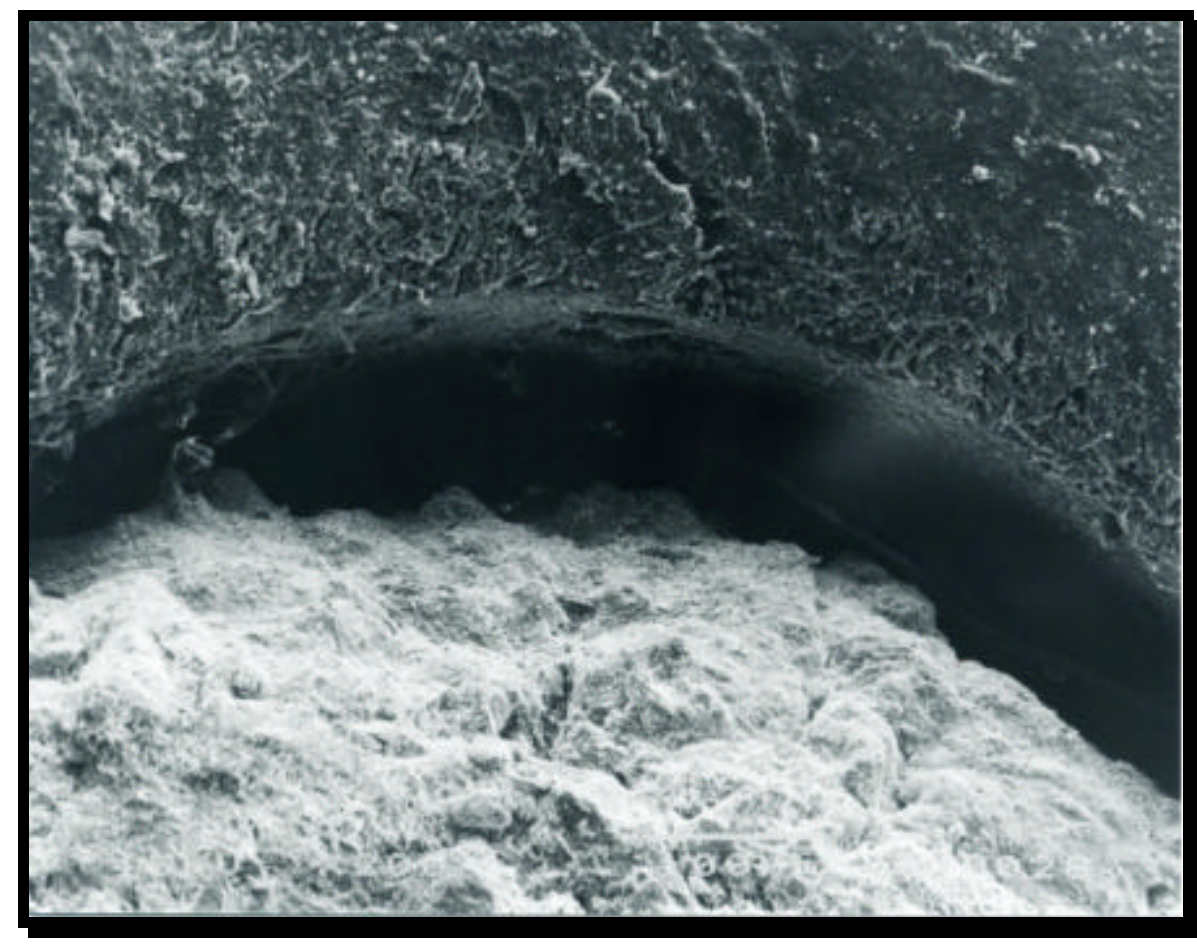

B

(aumento original $=200 \mathrm{X}$ )

Figura 17 (A e B) - Fotomicrografias da adaptação marginal da matriz de gesso Paris (sulfato de cálcio) às paredes dentinárias da perfuração 


\subsection{Materiais utilizados}

4.4.1 Cimento MTA - ANGELUS ${ }^{{ }^{*}}$ (Angelus Soluções Odontológicas - Londrina PR, Brasil). Apresenta embalagem composta por um vidro contendo 2 gramas de pó e um frasco contendo água destilada. O tempo de presa inicial, segundo o fabricante, é de 2 horas e 29 minutos e o final é de 3 horas e 37 minutos.

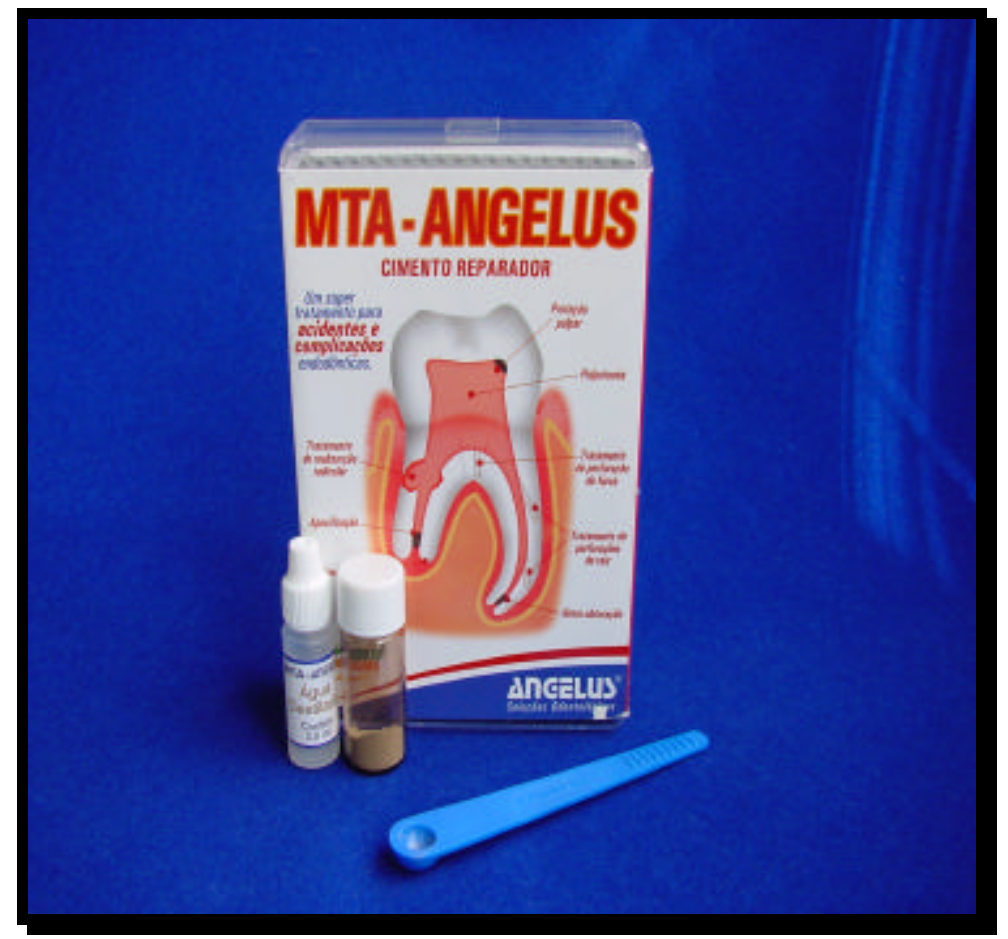

Figura 18 - Cimento MTA - Angelus (Angelus Soluções Odontológicas)

A sua fórmula apresenta a seguinte composição:

$\underline{\boldsymbol{P}}$ : Dióxido de silício, Óxido de potássio, Alumina, Óxido de sódio, Óxido férrico, Trióxido de enxofre, Óxido de cálcio, Óxido de Bismuto, Óxido de Magnésio, e resíduos insolúveis (sílica cristalina, óxido de cálcio, sulfato de potássio e sulfato de sódio).

Líquido: Água destilada 
A proporção utilizada nos experimentos foi a recomendada pelo fabricante, como sendo, 1 medida de pó para uma gota de água destilada. Após a mistura, obtinha-se um cimento arenoso e úmido.

4.4.2 Cimento ProRoot - $\mathrm{MTA}^{\mathrm{TM}^{*}}$ - Dentsply (Tulsa Dental, Tulsa OK, USA). Apresenta embalagem composta por dois saches contendo 1 grama de pó cada, e três recipientes contendo água destilada. O tempo de presa inicial é de 2 horas e 45 minutos e o final é de aproximadamente 4 horas.

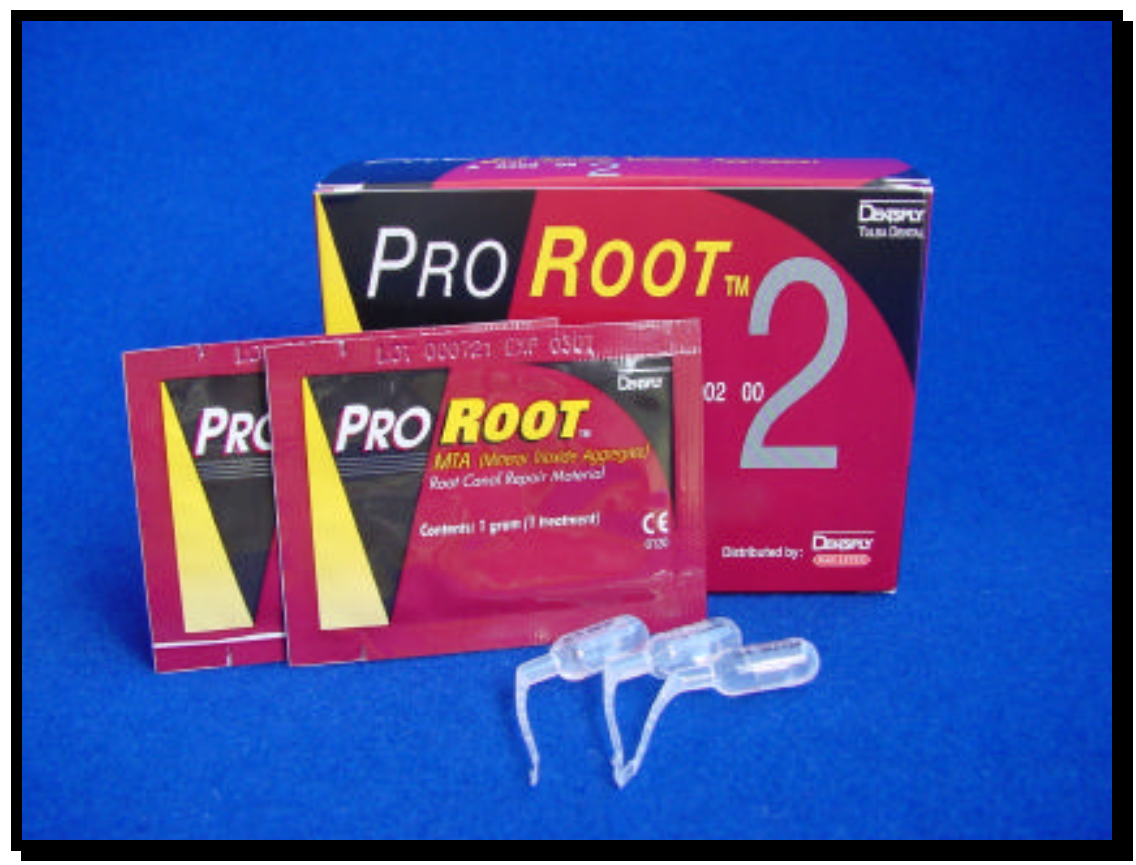

Figura 19 - Cimento ProRoot - MTA (Dentsply - Tulsa Dental)

A sua fórmula apresenta a seguinte composição:

Pó : $\quad$ Cimento Portland $\cong 75 \%$ em peso (Silicato tricálcico, Silicato dicálcico, Aluminato tricálcico, Aluminoferrato tetracálcico, Óxido silicato)

$\begin{array}{ll}\text { Óxido de Bismuto } & \cong 20 \% \text { em peso } \\ \text { Gesso } & \cong 5 \% \text { em peso }\end{array}$

Líquido: $\quad$ Água destilada 
A proporção utilizada nos experimentos foi a recomendada pelo fabricante, 3 partes de pó para uma de líquido. Após a mistura, obteve-se um cimento arenoso e úmido.

4.4.3 Cimento Super-EBA ${ }^{\mathrm{TM}^{*}}$ - Harry J. Bosworth Co. (Skokie, IL USA). Apresenta embalagem com dois frascos de pó, um com tempo de presa normal e o outro rápido. O líquido é o mesmo para os dois tipos de pó. Foi utilizado o pó com tempo de presa normal.

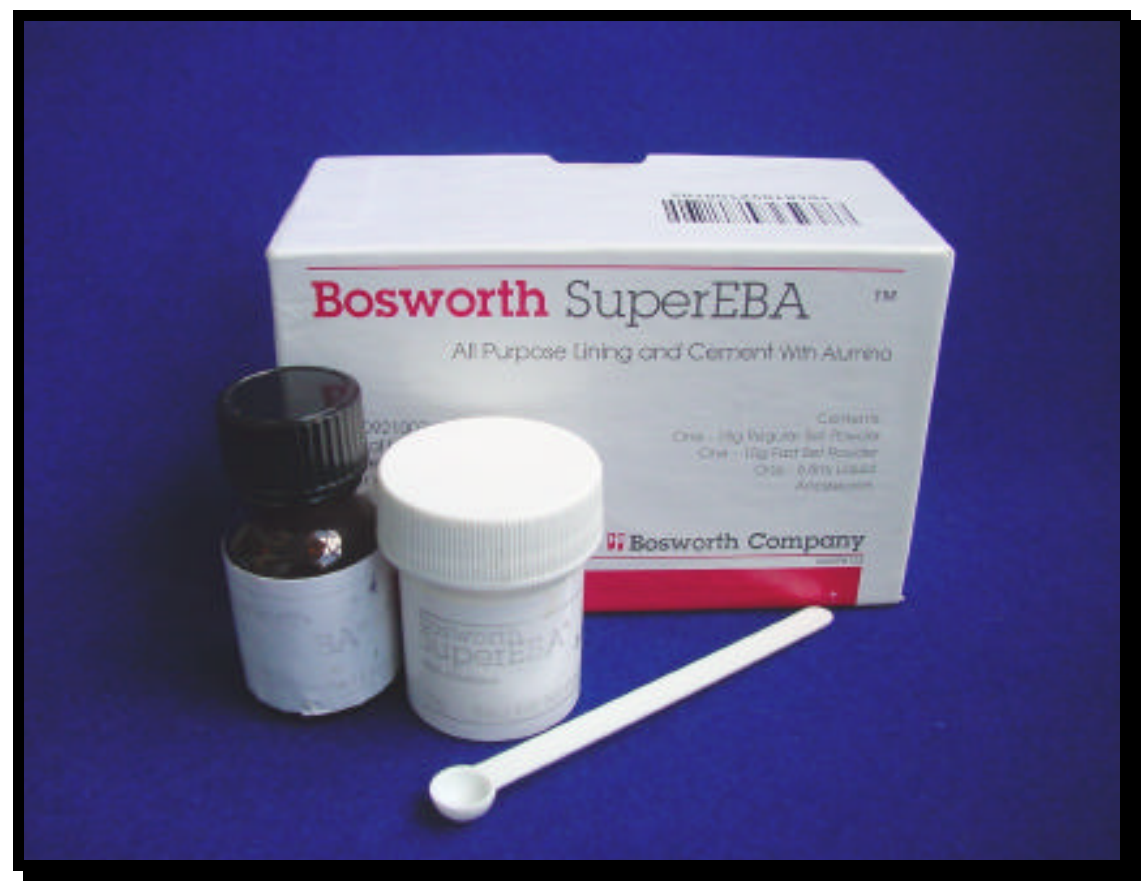

Figura 20 - Cimento Super-EBA (Harry J. Bosworth Co.)

A sua fórmula apresenta a seguinte composição:

$\begin{array}{lll}\text { Pó : } & \begin{array}{l}\text { Óxido de zinco } \\ \text { Óxido de alumínio }\end{array} & 60 \% \\ & \text { Resina natural } & 64 \% \\ & 6 & \\ \text { Líquido: } & \text { Ácido orto-etoxi benzóico } & 62,5 \% \\ & \text { Eugenol } & 37,5 \%\end{array}$


O tempo de presa normal varia de 3 a 6 minutos. A proporção utilizada nos experimentos foi de uma parte de pó do dosificador que acompanha o produto, para uma gota de líquido, resultando em um cimento espesso, semelhante à massa de vidraceiro.

4.4.4 Cimento MBP-c* ${ }^{*}$ cimento experimental resinoso com hidróxido de cálcio, desenvolvido na disciplina de Endodontia, da Faculdade de Odontologia de Bauru USP, pelo Prof. Dr. Ivaldo Gomes de Moraes. Apresenta embalagem com dois frascos contendo uma pasta base e uma pasta catalisadora.

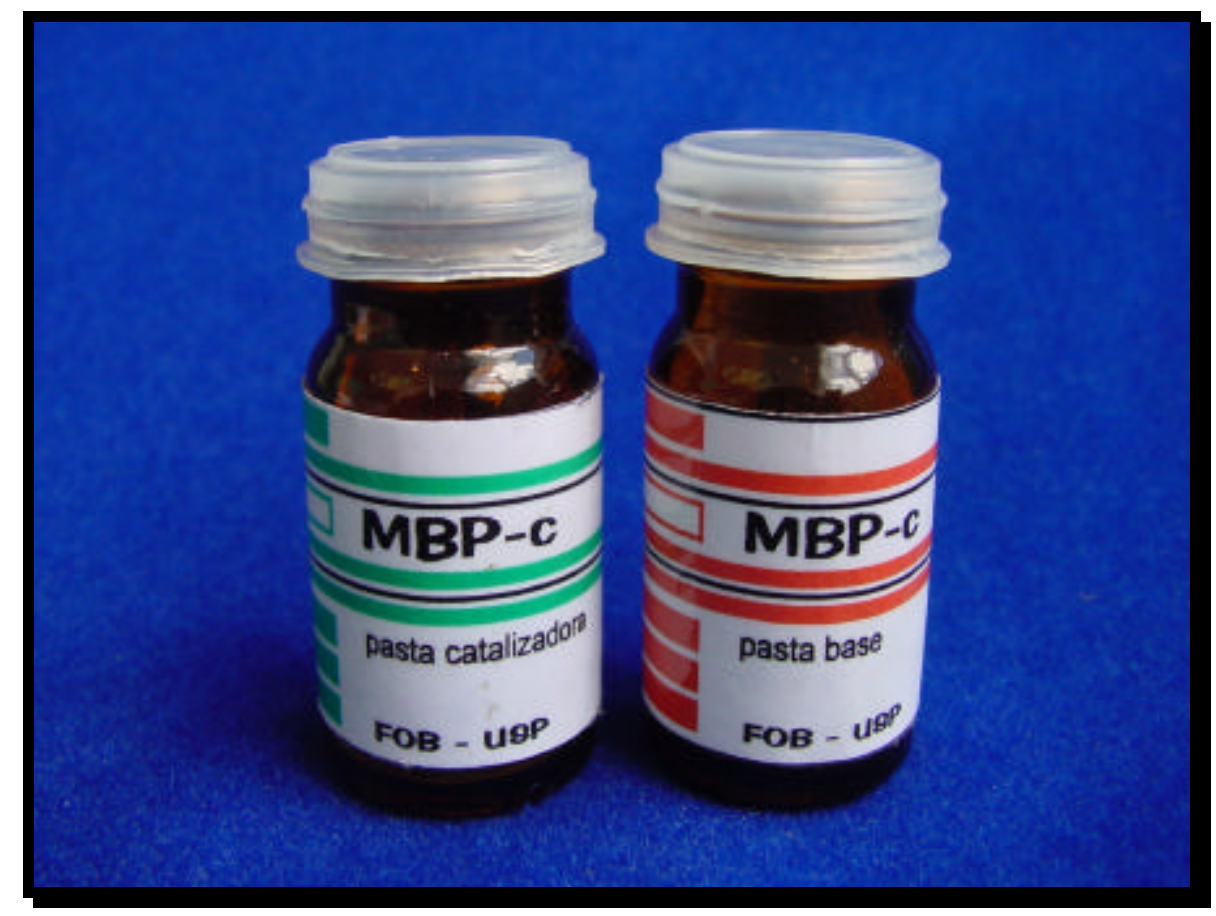

Figura 21 - Cimento MBP-c (Faculdade de Odontologia de Bauru - USP)

A sua fórmula apresenta a seguinte composição:

Pasta Base : Hidróxido de cálcio; Sulfato de Bário; Subnitrato de Bismuto; Resina epóxica. 
Pasta catalisadora: Sulfato de Bário; Subnitrato de Bismuto; Endurecedor para resina epóxica; Poliol de poliuretana vegetal de mamona.

O tempo de presa é de 4 horas, e a proporção do cimento utilizada nos experimentos foi de uma parte da pasta base para metade deste volume para a pasta catalisadora, resultando em um cimento espesso, semelhante à massa de vidraceiro.

4.4.5 Gesso Paris (sulfato de cálcio hemi-hidratado) - K-Dent (Quimidrol Ltda. Joinville - SC - Brasil). Utilizado para a confecção da matriz, que serviu de anteparo para a condensação dos materiais seladores. Misturou-se partes iguais de gesso Paris e água destilada, obtendo-se uma consistência espessa que permitia a introdução no interior da perfuração. 
5 RESULTA D O S 


\section{RESULTADOS}

As médias dos escores atribuídos à infiltração marginal de rhodamine $\mathrm{B}$ a $0,2 \%$ constatadas nos 10 espécimes de cada grupo cujas perfurações foram preenchidas com os cimentos testados estão apresentadas na Tabela 3 e 4 . A Tabela 3 acolhe os resultados das infiltrações nos espécimes nos quais a matriz de gesso Paris não foi utilizada. Já a Tabela 4 acolhe os resultados das infiltrações onde foi utilizada a matriz de gesso Paris.

Tabela 3 - Média, desvio padrão, $1^{\circ}$ quartil, mediana e $3^{\circ}$ quartil das infiltrações dos espécimes cujas perfurações foram preenchidas somente com os cimentos.

\begin{tabular}{c|c|c|c|c}
\hline Cimento & escore $(\mathbf{x} \pm \mathbf{d} \mathbf{p})$ & $\mathbf{1}^{\circ} \mathbf{Q}$ & Mediana & $\mathbf{3}^{\circ} \mathbf{Q}$ \\
\hline MTA - Angelus & $\mathbf{2 , 7} \pm 0,5$ & 2,0 & 3,0 & 3,0 \\
\hline ProRoot -MTA & $\mathbf{2 , 7} \pm 0,5$ & 2,0 & 3,0 & 3,0 \\
\hline Super-EBA & $\mathbf{1 , 1} \pm 0,7$ & 1,0 & 1,0 & 2,0 \\
\hline MBP-C & $\mathbf{0 , 4} \pm 0,5$ & 0,0 & 0,0 & 1,0 \\
\hline
\end{tabular}

Figura 22 - Gráfico representativo das médias dos escores das infiltrações marginais permitidas pelos cimentos testados. (sem matriz de gesso Paris)

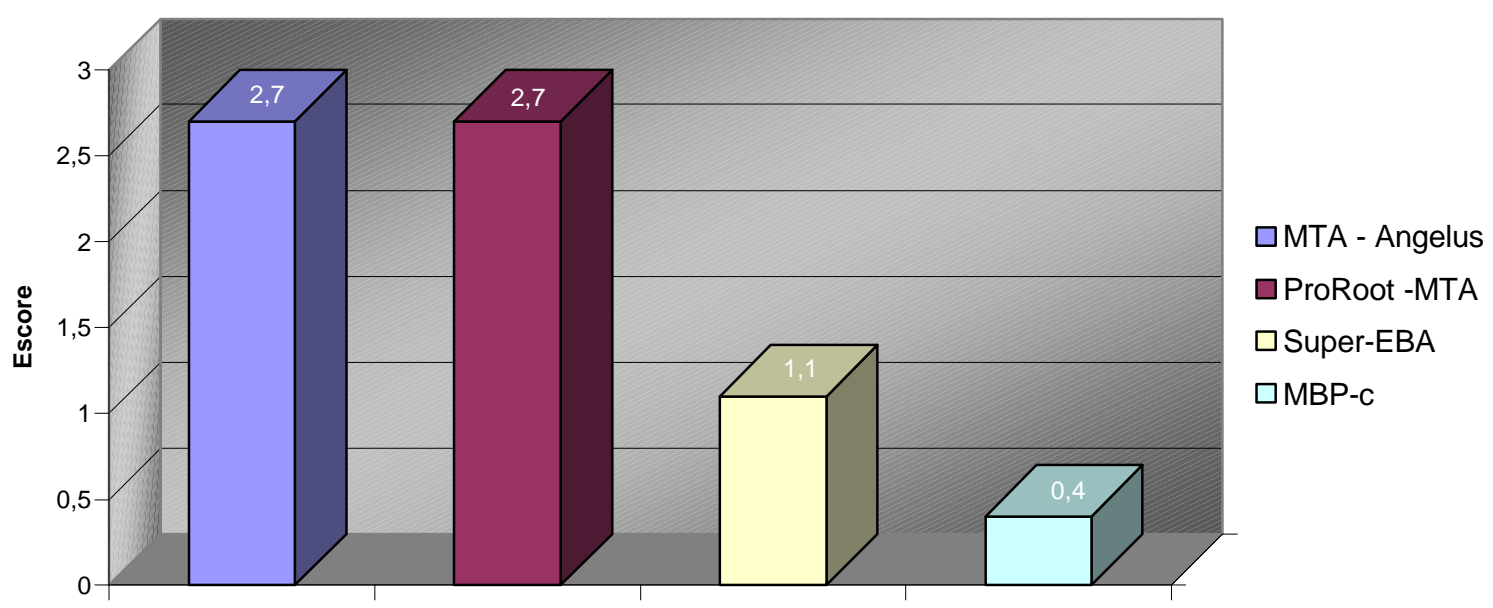


Tabela 4 - Média, desvio padrão, $1^{\circ}$ quartil, mediana e $3^{\circ}$ quartil das infiltrações dos espécimes cujas perfurações foram preenchidas com a presença da matriz de gesso Paris .

\begin{tabular}{c|c|c|c|c}
\hline Cimento & escore (x₫dp) & $\mathbf{1}^{\circ} \mathbf{Q}$ & Mediana & $\mathbf{3}^{\circ} \mathbf{Q}$ \\
\hline MTA - Angelus & $\mathbf{2 , 2} \pm 1,0$ & 2,0 & 2,5 & 3,0 \\
\hline ProRoot -MTA & $\mathbf{2 , 4} \pm 1,0$ & 2,0 & 3,0 & 3,0 \\
\hline Super-EBA & $\mathbf{2 , 1} \pm 1,0$ & 2,0 & 2,0 & 3,0 \\
\hline MBP-C & $\mathbf{1 , 0} \pm 0,5$ & 1,0 & 1,0 & 1,0 \\
\hline
\end{tabular}

Figura 23 - Gráfico representativo das médias dos escores das infiltrações marginais permitidas pelos cimentos testados. (com matriz de gesso Paris)

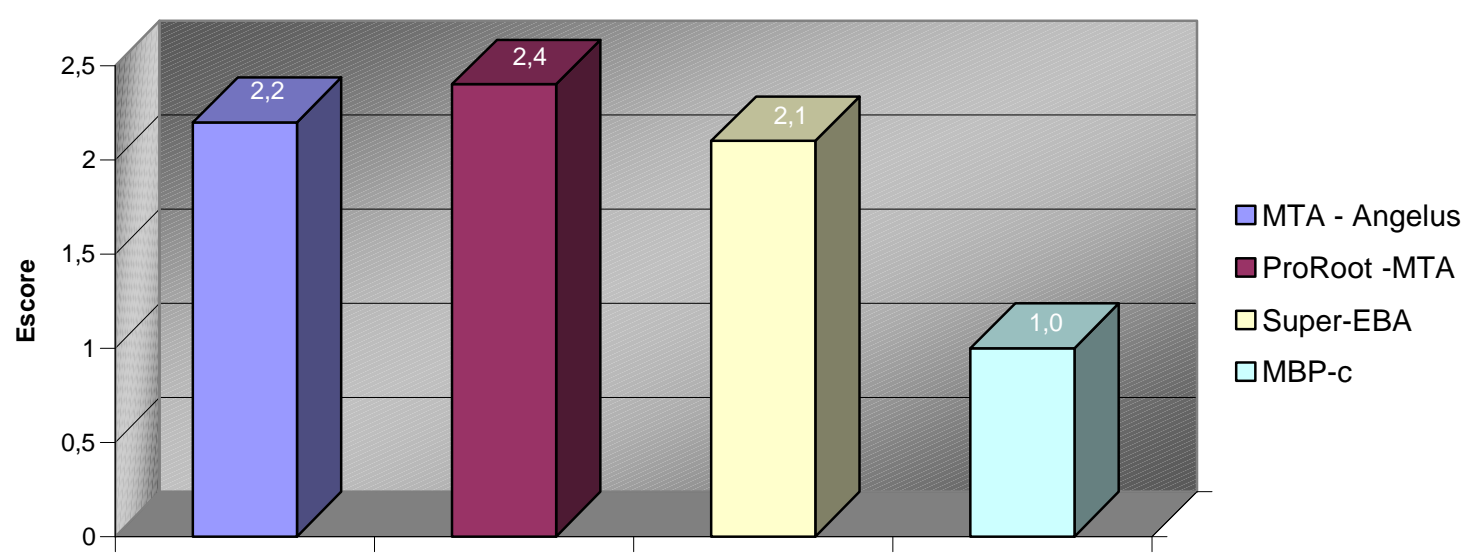

Nenhum espécime do grupo controle negativo apresentou infiltração de corante no trajeto da perfuração, enquanto que o grupo controle positivo apresentou completa marcação das paredes do trajeto da perfuração.

Detectou-se diferença estatisticamente significante na infiltração marginal dos cimentos em função da presença da matriz de gesso Paris para o Super-EBA e o MBPc, segundo o teste Mann-Whitney $(p<0,05)$, conforme mostra a Tabela 5, sendo que com a utilização da matriz a infiltração foi maior. 
Tabela 5 - Teste de Mann-Whitney - influência da matriz na infiltração marginal

\begin{tabular}{c|c|c|c}
\hline Cimento & $\mathbf{U}$ & $\mathbf{p}$ & Significância \\
\hline MTA - Angelus & 37,00 & 0,259 & NS \\
\hline ProRoot - MTA & 43,50 & 0,557 & NS \\
\hline Super-EBA & 20,50 & 0,020 & ${ }^{*}$ \\
\hline MBP-c & 23,00 & 0,017 & ${ }^{*}$ \\
\hline
\end{tabular}

* diferença estatisticamente significante $(p<0,05)$

NS - não significante

Quando as perfurações foram obturadas sem a matriz de gesso Paris, e submetidas ao teste de Kruskal-Wallis $(H=30,267 ; p<0,001)$ detectou-se diferença estatística significante. Quando comparados aos pares pelo teste de Dunn, houve diferença estatística conforme mostra a Tabela 6.

Tabela 6 - Teste de Dunn para comparação individual entre os quatro materiais na ausência da matriz de gesso Paris.

\begin{tabular}{c|c|c}
\hline Materiais comparados & Diferença de Rank: & Significânci \& \\
\hline MTA - Angelus X MBP-c & 22,150 & ${ }^{*}$ \\
\hline MTA - Angelus X Super-EBA & 16,050 & ${ }^{*}$ \\
\hline ProRoot - MTA X MTA - Angelus & 0,000 & NS \\
\hline ProRoot - MTA X MBP-c & 22,150 & ${ }^{*}$ \\
\hline ProRoot - MTA X Super-EBA & 16,050 & ${ }^{\star}$ \\
\hline Super-EBA X MBP-C & 6,100 & NS \\
\hline
\end{tabular}

${ }^{*}=$ diferença estatisticamente significante $(p<0,05)$

$\mathrm{NS}$ = não significante

Por meio do teste de Kruskal-Wallis para comparação global $(H=12,705 ; p=0,005)$ detectou-se diferença estatisticamente significante entre os cimentos obturadores na presença da matriz de gesso Paris. Como $p<0,05$ aceita-se que há diferenciação entre os grupos. Quando comparados aos pares pelo teste de Dunn, encontrou-se diferença estatística, conforme mostra a Tabela 7. 
Tabela 7 - Teste de Dunn para comparação individual entre os quatro materiais na presença da matriz de gesso Paris.

\begin{tabular}{c|c|c}
\hline Materiais comparados & Diferença de Rank: & Significânci : \\
\hline ProRoot - MTA X MBP-c & 16,200 & ${ }^{*}$ \\
\hline ProRoot - MTA X Super-EBA & 3,650 & NS \\
\hline ProRoot - MTA X MTA - Angelus & 2,350 & NS \\
\hline MTA - Angelus X MBP-c & 13,850 & ${ }^{*}$ \\
\hline MTA - Angelus X Super-EBA & 1,300 & NS \\
\hline Super-EBA X MBP-c & 12,550 & NS \\
\hline
\end{tabular}

${ }^{*}=$ diferença estatisticamente significante $(p<0,05)$

NS = não significante

$\mathrm{Na}$ análise em M.E.V da adaptação marginal dos cimentos às paredes dentinárias da perfuração, observou-se a presença de fendas marginais, com maiores desajustes, nos espécimes obturados com o MTA - Angelus e o ProRoot MTA em relação aos espécimes obturados com Super-EBA e com o MBP-c. Já, os espécimes obturados com o cimento MBP-c, mostraram melhores adaptações marginais quando comparados ao Super-EBA.

Analisando a adaptação marginal às paredes dentinárias da perfuração dos espécimes obturados, considerando-se a matriz de gesso Paris, observou-se, em alguns espécimes, a presença de fendas marginais e o preenchimento incompleto da cavidade da perfuração; em outros uma adaptação adequada, e, em alguns espécimes até um pequeno extravasamento do gesso Paris para fora da cavidade da perfuração. 


\section{DISCUSSÃO}

A variedade de materiais disponíveis no mercado para a obturação de perfurações dentárias é muito grande mas a procura pelo material ideal sempre foi e continua sendo muito intensa. O mesmo deve apresentar boas propriedades físicas sem deixar de lado a grande importância das propriedades biológicas. A cada propriedade melhorada de um material parece surgir uma nova propriedade ou dúvidas a respeito de uma já existente. Essa procura interminável é que motiva e mantém vivo o espírito pesquisador.

A capacidade de selamento e a adaptação marginal exercem influência na qualidade e no prognóstico do tratamento das perfurações radiculares e por isso é sempre conveniente avaliá-las naqueles materiais que são oferecidos para o fim determinado como é o caso dos cimentos MTA - Angelus, ProRoot - MTA, SuperEBA e MBP-c (experimental).

\subsection{Infiltração marginal}

A capacidade de selamento marginal é uma das propriedades físicas mais estudadas dos materiais endodônticos. Segundo TAYLOR; LYNCH ${ }^{100}$ (1992), várias metodologias podem ser utilizadas para este fim, dentre elas o método eletroquímico (DELIVANIS; CHAPMAN ${ }^{34}$, 1982), o uso de radioisótopos e obtenção de autorradiografias por DOW; INGLE ${ }^{36}$ (1955), MORAES $^{71}$ (1981).

O método de infiltração bacteriana, determina o tempo necessário para que o microorganismo penetre em uma determinada espessura do material testado. Esta metodologia foi estudada por TORABINEJAD et al. ${ }^{103}$ (1995), FISCHER; 
ARENS; MILLER $^{39}$ (1998), NAKATA; BAE; BAUMGARTNER ${ }^{73}$ (1998) e SCHEERER; STEIMAN; COHEN ${ }^{87}$ (2001).

A metodologia chamada "fluid transport model" desenvolvida por WU et al. $^{116}$ (1993) foi utilizada por BATES; CARNES; del RIO ${ }^{18}$ (1996); YATSUSHIRO; BAUMGARTNER; TINKLE ${ }^{123}$ (1998), KONTAKIOTIS; WU; WESSELINK ${ }^{57}$ (1997), WU; KONTAKIOTIS; WESSELINK ${ }^{117}$ (1998), WU; KONTAKIOTIS; WESSELINK ${ }^{118}$ (1998), YACINO et al. ${ }^{120}$ (1999), ADAMO et al. ${ }^{02}$ (1999), WELDON JR. et al. ${ }^{115}$ (2001), FOGEL; PEIKOFF ${ }^{41}$ (2001) onde se força a passagem de água sob pressão por um canal obturado e essa infiltração é quantificada pelo movimento de uma bolha de ar em um capilar preenchido com água ligado à outra extremidade da raiz.

AL-GHAMDI; WENNENBERG ${ }^{03}$ (1994) lembraram não haver norma que especifique procedimentos estandardizados para testes de infiltração, sendo o uso de corantes, como marcador de infiltração, a técnica mais antiga, simples e popular. Entretanto, há uma variedade muito grande de técnicas e metodologias, o que torna muito difícil uma padronização.

WU; WESSELINK ${ }^{119}$ (1993) relataram que mais trabalhos deveriam objetivar o estudo das metodologias de infiltração ao invés de continuarem avaliando a capacidade seladora dos materiais por diferentes técnicas que podem não fornecer informações com muita relevância.

Segundo PITT FORD et al. $^{84}$ (1995), a extrapolação direta e a relevância clínica de estudos de infiltração marginal por corante podem ser questionados. Entretanto, TAYLOR; LYNCH ${ }^{100}$ (1992); TORABINEJAD; WATSON; PITT FORD ${ }^{113}$ (1993), concordam que a avaliação do selamento por meio de estudos da microinfiltração marginal por traçadores, é um dos métodos mais fáceis para selecionar novas técnicas e materiais restauradores, pois "quando um material 
não permite a passagem de pequenas moléculas (corantes), apresenta o potencial de prevenir a infiltração de substâncias maiores como bactérias e suas toxinas" .

BRANDÃO $^{28}$ (1999) opinou que o teste de infiltração marginal , com suas enormes variáveis, ainda tem o seu lugar no estudo das propriedades dos cimentos endodônticos, possibilitando, no mínimo, a comparação dos resultados dos materiais testados sob as mesmas condições.

Alguns autores como OYNICK; OYNICK ${ }^{79}$ (1978), STABHOLZ et al. ${ }^{96}$ (1985), AUN et al. $^{12}$ (1989), BERNARDINELI ${ }^{21}$ (1993), TORABINEJAD et al. ${ }^{105}$ (1995), FITZPATRICK; STEIMAN ${ }^{40}$ (1997), TANOMARU FILHO; MENDONÇA; TANOMARU $^{99}$ (2001) utilizaram a microscopia eletrônica de varredura para avaliar a adaptação marginal dos materiais às paredes da cavidade, tentando estabelecer uma relação entre infiltração marginal e adaptação marginal.

Cada um desses métodos possui vantagens e desvantagens. A técnica de penetração de corante e seccionamento para medição da infiltração parece ser a mais fácil e freqüentemente mais utilizada, e por esse motivo optamos por sua utilização em conjunto com a adaptação marginal, visualizada sob microscopia eletrônica de varredura. 


\subsection{Discussão da metodologia}

Optou-se por uma avaliação in vitro em dentes molares humanos extraídos que apresentassem anatomia semelhante embora com raízes distintas, o que possibilitou uma análise em regiões de bifurcações, quando em molares inferiores, ou trifurcações em molares superiores. Tal grupamento dental foi escolhido devido à maior ocorrência desse acidente clínico nestes elementos dentários, conforme atestaram INGLE ${ }^{53}$ (1962); CATTONI ${ }^{29}$ (1963); KVINNSLAND et al. ${ }^{60}$ (1989) e $\operatorname{ALHADAINY}^{05}$ (1994).

Muitos autores, pesquisando as perfurações radiculares, utilizaram-se de molares inferiores e superiores, dentre eles (LEE; MONSEF; TORABINEJAD ${ }^{62}$, 1993, ALHADAINY; HIMEL ${ }^{08}, 1993$, ALHADAINY; HIMEL ${ }^{09}, 1993$, ALHADAINY; HIMEL $^{07}$, 1994, HIMEL; ALHADAINY ${ }^{47}$, 1995, CHAU et al. ${ }^{30}$ 1997, MANNOCCI; VICHI; FERRARI ${ }^{65}, 1997$, SHIMABUKO ${ }^{90}, 1997$, MACHADO; FERNANDES ${ }^{64}$, 1997, ALHADAINY; ABDALLA ${ }^{06}$, 1998, SLUYK; MOON; HARTWELL ${ }^{93}, 1998$, MITTAL; CHANDRA; CHANDRA ${ }^{68}, 1999$, VINHOLES $\left.^{114}, 2000\right)$. Entretanto, AUN et al. $^{12}$ (1989), DAZEY; SENIA ${ }^{33}$ (1990), MOLONEY; FEIK; ELLENDER ${ }^{69}$ (1993) e TANOMARU FILHO; MENDONÇA; TANOMARU ${ }^{99}$ (2001), em seus trabalhos, utilizaram-se de dentes monorradiculados, fazendo perfurações laterais.

No presente estudo, o armazenamento dos dentes em solução aquosa de formol 10\%, visou a fixação e estabilidade da matéria orgânica, evitando sua putrefação e mantendo-os hidratados (BERNARDINELI ${ }^{21}$, 1993, TORABINEJAD et al. ${ }^{105}$ 1995, O' CONNOR; HUTTER; ROAHEN ${ }^{76}$, 1995, CHAU et al. ${ }^{30} 1997$, PAVAN $^{81}, 1999$, KUBO $^{59} 2001$, SILVA NETO et al. ${ }^{91}$ 2001). 
De acordo com a metodologia proposta por SLUYK; MOON; HARTWELL ${ }^{93}$ (1998) as coroas foram removidas em um nível logo acima do assoalho da câmara pulpar, e as raízes, logo abaixo da região de furca, de maneira que o segmento relacionado com o assoalho da câmara pulpar permanecesse intacto e facilitasse a manipulação durante as fases da pesquisa, permitindo condições semelhantes de trabalho em todos os espécimes. Além disso, a remoção das raízes proporcionou uma visualização completa da região de furca no momento da avaliação sob M.E.V.

A impermeabilização externa, com uma ou duas camadas de esmalte, é a mais utilizada nos trabalhos, e muitos autores como (MORAES ${ }^{71}$, 1981, MORAES $^{72}, 1984$, BONDRA et al. ${ }^{24}$ 1989, LEE; MONSEF; TORABINEJAD ${ }^{62}, 1993$, ALHADAINY; HIMEL ${ }^{08}$, 1993, ALHADAINY; HIMEL ${ }^{09}, 1993$, TORABINEJAD; WATSON; PITT FORD ${ }^{113}$, 1993, ALHADAINY; HIMEL ${ }^{07}, 1994$, HIMEL; ALHADAINY $^{47}$, 1995, CHAU et al. ${ }^{30}$, 1997, MANNOCCI; VICHI; FERRARI ${ }^{65}$, 1997, ALHADAINY; ABDALA $^{06}$, 1998, MITTAL; CHANDRA; CHANDRA $^{68}$, 1999, AQRABAWI $^{10}, 2000$, VINHOLES $^{114}, 2000$, DALÇÓQUIO et al. ${ }^{32} 2001$ KUBO $^{59}$, 2001) salientaram a importância da impermeabilização externa para não permitir a penetração de marcadores pelos túbulos dentinários e canais acessórios. Entretanto, outros materiais também podem ser utilizados, como a cera pegajosa (DOW; INGLE ${ }^{36}$, 1955, TORABINEJAD et al. ${ }^{106}$ 1994, HOLT; DUMSHA ${ }^{52}, 2000$ ), cianoacrilato de etila (SHIMABUKO ${ }^{90}$, 1997, MACHADO; FERNANDES ${ }^{64}$, 1997). Neste trabalho utilizou-se uma camada de Araldite e duas de esmalte para unhas,

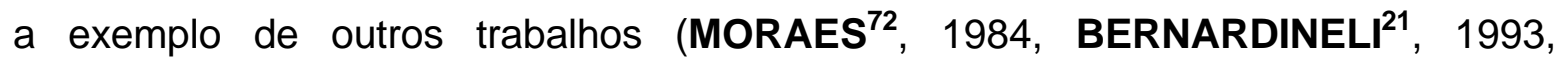
YAMASHITA et al. ${ }^{121}$ 1999, TANOMARU FILHO et al. ${ }^{98}$ 1999, PAVAN $^{81}, 1999$, BRANDÃO $^{28}$, 1999, SILVA NETO et al. ${ }^{91}$ 2001). Essa técnica de impermeabilização 
mostrou-se bastante eficiente, visto que os controles negativos não apresentaram nenhuma infiltração de corante.

A obtenção de alvéolos artificiais em silicona pesada, conforme modelo proposto por AUN et al. ${ }^{12}$ (1989) e também utilizado por (DAZEY; SENIA ${ }^{33} 1990$, MANNOCCI; VICHI; FERRARI ${ }^{65}$ 1997, SHIMABUKO ${ }^{90}$ 1997), mostrou-se um método eficaz para simulação das condições clínicas, possibilitando uma uniformidade durante o preenchimento das perfurações, e limitando a movimentação dos espécimes.

Os dentes foram perfurados perpendicularmente no centro do assoalho da câmara pulpar com brocas esféricas nํㄹ, em alta rotação, receberam irrigação com hipoclorito de sódio a $1 \%$ e ao final com soro fisiológico, de acordo com os trabalhos de DAZEY; SENIA ${ }^{33}$ (1990), LEE; MONSEF; TORABINEJAD ${ }^{62}$; (1993), ALHADAINY; HIMEL ${ }^{08}$ (1993), ALHADAINY; HIMEL ${ }^{09}$ (1993), ALHADAINY; HIMEL $^{07}$ (1994), HIMEL; ALHADAINY ${ }^{47}$ (1995), MANNOCCI; VICHI; FERRARI ${ }^{65}$ (1997), CHAU et al. ${ }^{30}$ (1997), SLUYK; MOON; HARTWELL ${ }^{93}$ (1998), ALHADAINY; ABDALLA $^{06}$ (1998), MITTAL; CHANDRA; CHANDRA ${ }^{68}$ (1999). Porém, SHIMABUKO $^{90}$ (1997), MACHADO; FERNANDES ${ }^{64}$ (1997) realizaram as perfurações com brocas esféricas $\mathrm{n} \cong 3$, e outros autores como AUN et al. ${ }^{12}$ (1989), MOLONEY; FEIK; ELLENDER ${ }^{69}$ (1993) e TANOMARU FILHO; MENDONÇA; TANOMARU ${ }^{99}$ (2001) fizeram uso de brocas diferentes dessas já mencionadas.

De acordo com o estudo de SLUYK; MOON; HARTWELL ${ }^{93}$ (1998), a perfuração foi ampliada com uma broca Gates-Glidden $\mathrm{n}^{\circ} 5$, com objetivo de regularizar e estabelecer um diâmetro padronizado de 1,4mm. A profundidade da perfuração, todavia, uma variável incontrolável, foi determinada pela espessura dentina-cemento do assoalho da câmara pulpar, apoiado nos trabalhos de 
ALHADAINY; HIMEL ${ }^{08}$ (1993), ALHADAINY; HIMEL ${ }^{09}$, (1993), ALHADAINY; HIMEL $^{07}$ (1994), HIMEL; ALHADAINY ${ }^{47}$ (1995), CHAU et al. ${ }^{30}$ (1997), ALHADAINY; ABDALLA $^{06}$ (1998), MITTAL; CHANDRA; CHANDRA ${ }^{68}$ (1999).

Convém ressaltar que o assoalho da câmara pulpar localiza-se, geralmente, abaixo do limite amelo-cementário, tanto nos molares superiores quanto em inferiores. É importante registrar que, a relação do assoalho da câmara pulpar com a região de furca, segundo MARTOS; SILVEIRA ${ }^{66}$ (1999) apresenta um valor médio de 2,622mm para os molares superiores e $1,859 \mathrm{~mm}$ para os inferiores. A fim de contornar essa variável, os espécimes foram medidos com um paquímetro, buscando conferir a maior homogeneização possível dos grupos e utilizando-se apenas molares com espessura de assoalho variando entre 2 e $3 \mathrm{~mm}$.

Em vista do exposto acima, no momento da formação dos grupos, os espécimes com maior espessura de assoalho da câmara pulpar compuseram os grupos que receberam a aplicação de uma matriz de gesso Paris, e os outros com menor espessura, receberam apenas o material obturador.

Conforme trabalhos de ALHADAINY; HIMEL ${ }^{08}$ (1993), ALHADAINY; HIMEL $^{07}$ (1994), HIMEL; ALHADAINY ${ }^{47}$ (1995), CHAU et al. ${ }^{30}$ (1997), SHIMABUKO $^{90}$ (1997), ALHADAINY; ABDALLA ${ }^{06}$ (1998), MITTAL; CHANDRA; CHANDRA $^{68}$ (1999) foram utilizadas bolinhas de algodão, umedecidas com água destilada, simulando as condições clínicas quanto ao aspecto de umidade e resistência à compressão dos tecidos de suporte. Entretanto, é importante ressaltar que para simular o ambiente clínico SLUYK; MOON; HARTWELL ${ }^{93}$ (1998) utilizaram-se do Gelfoam, e LEE; MONSEF; TORABINEJAD ${ }^{62}$ (1993), MANNOCCI; VICHI; FERRARI ${ }^{65}$ (1997) utilizaram uma esponja umedecida com solução fisiológica. 
BENENATI et al. ${ }^{20}$ (1986), afirmaram que $69 \%$ dos insucessos no tratamento de perfurações radiculares são referentes à extrusão dos materiais. A preocupação referente ao extravasamento dos materiais para os tecidos periodontais, e sua influência no prognóstico dos casos de perfurações radiculares, impulsionou autores como AUSLANDER; WEINBERG ${ }^{14}$, (1989), LEMON ${ }^{63}$ (1992), HARTWELL; ENGLAND ${ }^{46}$, (1993) a utilizarem materiais servindo como matriz, de modo que esta possa evitar a presença de umidade, atuar como barreira ao extravasamento, e permitir uma condensação mais eficiente do material selador.

Dentre os materiais utilizados, destacam-se a hidroxiapatita utilizada por LEMON ${ }^{63}$ (1992), o cimento de fosfato de cálcio por CHAU et al. ${ }^{30}$ (1997), hidróxido de cálcio (MACHADO;FERNANDES ${ }^{64}, 1997$, SHIMABUKO $\left.{ }^{90}, 1997\right)$ e materiais restauradores temporários (AUN et al. ${ }^{12}$ 1989, SHIMABUKO ${ }^{90}, 1997$ ).

A utilização do gesso Paris no tratamento de perfurações na região de furca, encontra justificativa nos trabalhos de ALHADAINY; HIMEL ${ }^{07}$ (1994), HIMEL; ALHADAINY $^{47}$ (1995), ALHADAINY; ABDALLA ${ }^{06}$ (1998) a exemplo de MITTAL;

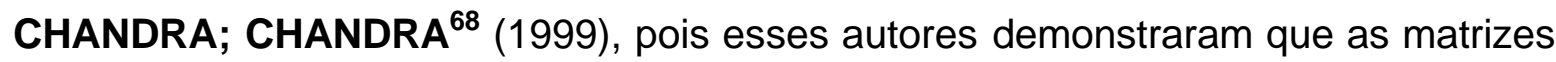
de gesso Paris propiciavam menores índices de extravasamento do material quando comparadas aos casos em que não eram utilizadas.

É importante salientar, que o objetivo da utilização da matriz de gesso Paris (sulfato de cálcio), refere-se principalmente, à prevenção da extrusão do material para região de furca e não na melhoria da capacidade de selamento, visto que ALHADAINY; HIMEL ${ }^{07}$ (1994) demonstraram a permeabilidade desse material, permitindo total infiltração quando utilizado como barreira ou matriz.

BAHN $^{15}$ (1966) exaltou as propriedades e defendeu a utilização do gesso Paris (sulfato de cálcio) por ser um material estável, biocompatível, 
prontamente disponível, esterilizável e por seu grau de reabsorção coincidir com o grau de formação óssea. YAMAZAKI et al. ${ }^{122}$ (1988) afirmaram que o gesso Paris acelera o grau de mineralização óssea por meio de uma fonte de íons cálcio.

A confecção da matriz foi realizada conforme metodologia proposta por CHAU et al. $^{30}$ (1997) onde após quinze minutos da inserção e compactação do gesso Paris no interior da perfuração, a porção mais coronal foi removida com ajuda de uma lima Flex-R n¹00; preparada para atuar adaptada às paredes da cavidade da perfuração, deixando uma camada de aproximadamente $0,5 \mathrm{~mm}$ de gesso Paris atapetando o fundo da perfuração. Neste trabalho utilizou-se uma lima tipo Kerr nำ110 também preparada com o mesmo objetivo.

Para obturação das perfurações foi utilizado o cimento Super-EBA, um material introduzido por OYNICK; OYNICK $^{79}$ (1978), composto basicamente por óxido de zinco e eugenol, resina e ácido orto-etoxybenzóico, tendo sido muito utilizado no selamento de cavidades de obturações retrógradas. Para o selamento de perfurações radiculares foi utilizado por OYNICK; OYNICK ${ }^{80}$ (1985); MOLONEY; FEIK; ELLENDER $^{69}$ (1993); BOGAERTS $^{22}$ (1997) demonstrando resultados satisfatórios.

No presente estudo, o ProRoot - MTA e o MTA - Angelus, nomes comerciais do agregado de trióxido mineral, foram também utilizados no preenchimento das perfurações. Tais produtos, segundo os fabricantes e TORABINEJAD; CHIVIAN ${ }^{112}$ (1999), além de sua utilização no selamento de perfurações radiculares, pode ser indicado como material retroobturador, no capeamento pulpar direto e pulpotomia de dentes com ápices radiculares incompletos e sem sintomatologia de alterações pulpares irreversíveis; como "plug" 
apical para o selamento de dentes com rizogênese incompleta; e como tampão cervical, previamente aos procedimentos de clareação interna.

Além disso, vários estudos têm demonstrado sua biocompatibilidade (PITT FORD et al. $^{84}$ 1995, KETTERING; TORABINEJAD ${ }^{56}, 1995$, TORABINEJAD et al. ${ }^{110}$ 1995, HOLLAND et al. ${ }^{50}$ 1999), bem como tentam explicar o mecanismo de indução do reparo biológico (HOLLAND et al. ${ }^{49}$ 2001, HOLLAND et al. ${ }^{51}$ 2001).

Um cimento à base de resina epóxica, contendo hidróxido de cálcio e um componente de resina poliuretana vegetal, derivado dos experimentos realizados por MORAES ${ }^{72}$ (1984) foi também utilizado nesta pesquisa. Este cimento experimental, denominado de MBP-c, pode ser utilizado no tratamento de perfurações radiculares como também em obturações retrógradas.

O uso de corantes como marcadores de infiltração marginal tem se mostrado bastante simples, barato, eficiente, além de não exigir equipamentos laboratoriais mais complexos.

Vários corantes em diferentes concentrações têm sido utilizados nos estudos de infiltração, entre eles o nitrato de prata por HOLT; DUMSHA ${ }^{52}$ (2000); a Erythrocina B 2\% por ALHADAINY; HIMEL ${ }^{08}$ (1993), ALHADAINY; HIMEL ${ }^{09}$ (1993), ALHADAINY; HIMEL ${ }^{07}$ (1994); tinta da Índia por BONDRA et al. ${ }^{24}$ (1989), CHAU et al. $^{30}$ (1999); o azul de metileno 0,5\% por MACHADO; FERNANDES ${ }^{64}$ (1997); o azul de metileno $1 \%$ por TORABINEJAD et al. ${ }^{106}$ (1994), BRANDÃO ${ }^{28}$ (1999), AQRABAWI $^{10}$ (2000), DALÇÓQUIO et al. $^{32}$ (2001); azul de metileno $2 \%$ por MOARES $^{72}$ (1984), DAZEY; SENIA ${ }^{33}$ (1990), LEE; MONSEF; TORABINEJAD 62 (1993), BERNARDINELI ${ }^{21}$ (1993), HIMEL; ALHADAINY ${ }^{47}$ (1995), MANNOCCI; VICHI; FERRARI $^{65}$ (1997), ALHADAINY; ABDALLA ${ }^{06}$ (1998), MITTAL; CHANDRA; CHANDRA $^{68}$ (1999), PAVAN $^{81}$ (1999), TANOMARU FILHO et al. ${ }^{98}$ (1999), 
YAMASHITA et al. ${ }^{121}$ (1999); e por fim a utilização da rhodamine $B$ fluorescente por TORABINEJAD; WATSON; PITT FORD ${ }^{113}$ (1993); rhodamine $B$ 0,1\% por CHRISTEN; MITCHELL ${ }^{31}$ (1966); rhodamine B 0,2\% por MORAES ${ }^{71}$ (1981), SILVA NETO et al. ${ }^{91}$ (2001); rhodamine B 1\% por SHIMABUKO ${ }^{90}$ (1997); rhodamine B 2\% por VINHOLES ${ }^{114}(2000)$, KUBO$^{59}(2001)$.

Para HAMAOKA ${ }^{45}$ (1995), dentre três corantes analisados para avaliar a permeabilidade da dentina radicular, a rhodamine B apresentou, estatisticamente, os maiores valores de infiltração $(40,8 \%)$, seguida pelo azul de metileno $(14,5 \%)$ e pela tinta da Índia (7,5\%), que apresentou o menor valor de penetração.

Já que $0,1 \%$ é uma concentração que possibilita marcação da infiltração e, concentrações muito mais altas parecem só aumentar o grau de manchamento, foi utilizada a concentração de $0,2 \%$ seguindo a metodologia proposta por MORAES ${ }^{71}$ (1981) e utilizada também por SILVA NETO et al. ${ }^{91}$ (2001).

WU; WESSELINK ${ }^{119}$ (1993) lembraram que o $\mathrm{pH}$ do corante é outra variável que pode alterar a quantidade de infiltração. Isso foi provado por STARKEY; ANDERSON; PASHLEY ${ }^{97}$ (1993) mostrando que pH abaixo de 5,0 provoca perdas consideráveis de estrutura dental, o que não ocorre com pH 7,0 concluindo, portanto, que o ajuste do $\mathrm{pH}$ é importante em estudos de infiltração e alguns trabalhos têm tido o cuidado de usar a rhodamine $\mathrm{B}$ com pH neutro (SILVA NETO et al. $\left.{ }^{91} 2001, \mathrm{KUBO}^{59}, 2001\right)$. A solução de rhodamine B utilizada nesta pesquisa teve pH neutralizado em tampão de fosfato.

KONTAKIOTIS; WU; WESSELINK ${ }^{57}$ (1997) verificaram baixos valores de infiltração do azul de metileno quando empregaram um curativo prévio de hidróxido de cálcio levantando a hipótese da incompatibilidade do azul de metileno 
com substâncias alcalinas. Fenômeno também observado por NUNES ${ }^{75}$ (1999) e MORAES et al. ${ }^{70}(2000)$.

WU; KONTAKIOTIS; WESSELINK ${ }^{117}$ (1998) demonstraram que o $\mathrm{pH}$ alcalino de certos materiais (como o hidróxido de cálcio e o MTA) e agentes redutores podem transformar o azul de metileno em uma substância incolor, podendo mascarar os resultados reais de infiltração e fornecer resultados não confiáveis, isto é, falso negativos. Assim, os autores alertam que vários trabalhos que mensuraram a penetração do azul de metileno nos espaços vazios, em selamento com materiais alcalinos podem ter tido os seus resultados analisados de maneira incorreta. Também sugerem o emprego de outras substâncias marcadoras.

TORABINEJAD; WATSON; PITT FORD ${ }^{113}$ (1993) relataram que em um teste piloto não observaram infiltrações no MTA quando foi utilizado o azul de metileno. Entretanto, quando foi utilizada a solução de rhodamine $B$, a infiltração marginal ocorreu.

Baseados nos trabalhos citados anteriormente e na maior eficiência de penetração observada por HAMAOKA ${ }^{45}$ (1995), foi utilizado, neste trabalho, o corante rhodamine $\mathrm{B}$ em solução a $0,2 \%, \mathrm{pH} 7,0$, em tampão fosfato, durante 48 horas. De fato, pode-se comprovar a eficiência de penetração do marcador utilizado pois, ocorreu a infiltração de corante por toda a estrutura dentária nos quatro espécimes do grupo controle negativo. Com relação aos quatro espécimes do grupo controle positivo, foi comprovada a eficiência da técnica da impermeabilização utilizada pois foi observada uma completa impermeabilização de toda estrutura dentária.

A imersão imediata foi utilizada, pois, do ponto de vista clínico, a infiltração começa a ocorrer imediatamente após a obturação, e a colocação dos 
espécimes em corante após a presa poderia apresentar resultados diferentes, devido à variação dimensional que os materiais poderiam sofrer durante a presa em diferentes ambientes. Entretanto, POLLARD; WELLER; KULILD ${ }^{85}$ (1990) e KÜÇÜKAY; KÜÇÜKAY; BAYIRLI ${ }^{55}$ (1993) não encontraram diferenças significativas entre os grupos imersos imediatamente ou após certos períodos, achando que as falhas ocorrem durante a preparação, mas afirmaram que materiais diferentes daqueles que foram utilizados por eles podem apresentar resultados diferentes, daí o cuidado observado.

Apesar de SPANGBERG; ACIERNO; CHA $^{95}$ (1989) terem conseguido melhores resultados com imersão dos espécimes em ambiente a vácuo, alegando que bolhas de ar no interior da obturação podem inibir a penetração do corante, optou-se, neste trabalho, pela imersão passiva, pois KÜÇÜKAY; KÜÇÜKAY ; BAYIRLI $^{55}$ (1993), não encontraram diferença estatisticamente significante entre os dois tipos de imersão.

MORAES $^{72}$ (1984) demonstrou que o período de imersão pode afetar os resultados, pois encontrou maiores infiltrações após imersão em corantes por períodos mais longos. Embora, SHIMABUKO ${ }^{90}$ (1997) e VINHOLES $^{114}$ (2000) tenham utilizado o período de 7 dias de imersão na rhodamine B e TORABINEJAD; WATSON; PITT FORD ${ }^{113}$ (1993), KUBO ${ }^{59}$ (2001), MORAES ${ }^{71}$ (1981) acharem necessário apenas o período de 24 horas, optou-se por um período de 48 horas, estabelecendo um período de imersão intermediário, também utilizado por SILVA NETO et al. ${ }^{91}$ (2001) e por outros autores (LEE; MONSEF; TORABINEJAD ${ }^{62}, 1993$, CHAU et al. ${ }^{30} 1997$, MANNOCCI; VICHI; FERRARI ${ }^{65} 1997$, TANOMARU FILHO et al. $^{98}$ 1999, YAMASHITA et al. ${ }^{121}$ 1999), mesmo utilizando-se de outros marcadores. 
O método mais utilizado para expor a interface obturação/parede dentinária e possibilitar a medida da infiltração do marcador é o seccionamento longitudinal. (DAZEY; SENIA ${ }^{33}$, 1990, ALHADAINY; HIMEL ${ }^{08}, 1993$, ALHADAINY; HIMEL $^{09}$, 1993, LEE; MONSEF; TORABINEJAD ${ }^{62}$, 1993, TORABINEJAD; WATSON; PITT FORD ${ }^{113}, 1993$, BERNARDINELI ${ }^{21}, 1993$, TORABINEJAD et al. $^{106}$ 1994, ALHADAINY; HIMEL ${ }^{07}$, 1994, HIMEL; ALHADAINY ${ }^{47}$, 1995, O CONNOR; HUTTER; ROAHEN ${ }^{76}$ 1995, MANNOCCI; VICHI; FERRARI ${ }^{65}$, 1997, CHAU et al. $^{30}$ 1997, SHIMABUKO ${ }^{90}$, 1997, ALHADAINY; ABDALLA ${ }^{06}$, 1998, MITTAL; CHANDRA; CHANDRA ${ }^{68}, 1999$, BRANDÃO $^{28}, 1999$, PAVAN $^{81}, 1999$, TANOMARU FILHO et al. ${ }^{98} 1999$, YAMASHITA et al. ${ }^{121} 1999$, HOLT; DUMSHA ${ }^{52}$ 2000, AQRABAWI ${ }^{10}, 2000$, VINHOLES ${ }^{114}, 2000$, SILVA NETO et al. ${ }^{91} 2001$, KUBO $^{59}$, 2001). Optou-se, neste trabalho, pelo seccionamento longitudinal, com disco diamantado, devido à facilidade e domínio da técnica, além de diminuir o número de variáveis presentes em uma técnica mais sofisticada.

Após o seccionamento, não foi observado deslocamento do material obturador. Em tal circunstância, por estarem em um mesmo plano, dentina, interface e obturação, a visualização e leitura da extensão linear do corante ficaram bastante facilitadas.

A leitura em microscopia óptica conforme o processo descrito, é de execução bastante simples, não necessitando de sofisticação alguma e oferece resultados confiáveis o que, ainda, o torna válido. Vários autores como MORAES ${ }^{72}$ (1984), DAZEY; SENIA ${ }^{33}$ (1990); ALHADAINY; HIMEL ${ }^{08}$ (1993), ALHADAINY; HIMEL $^{09}$, (1993), LEE; MONSEF; TORABINEJAD ${ }^{62}$ (1993), BERNARDINELI ${ }^{21}$ (1993), TORABINEJAD et al. ${ }^{106}$ (1994), ALHADAINY; HIMEL ${ }^{07}$ (1994); MANNOCCI; VICHI; FERRARI ${ }^{65}$ (1997), CHAU et al. ${ }^{30}$ (1997), MITTAL; 
CHANDRA; CHANDRA $^{68}$ (1999), BRANDÃO28 (1999), TANOMARU FILHO et al. ${ }^{98}$ (1999), YAMASHITA et al. ${ }^{121}$ (1999), AQRABAWI ${ }^{10}$ (2000), VINHOLES ${ }^{114}$ (2000), KUBO $^{59}$ (2001) e SILVA NETO et al. ${ }^{91}$ (2001) utilizaram-se desse método.

Outro método de mensuração, baseado numa análise da área de penetração de corante, avaliado pela captação de imagem e contagem de "pixels" por um microcomputador foi utilizada por HIMEL; ALHADAINY ${ }^{47}$ (1995), MACHADO; FERNANDES ${ }^{64}$ (1997), SHIMABUKO ${ }^{90}$ (1997), ALHADAINY; $\operatorname{ABDALLA}^{06}$ (1998) e $\operatorname{PAVAN}^{81}$ (1999).

A atribuição de escores numéricos para obtenção de uma média de acordo com TORABIBEJAD; WATSON; PITT FORD ${ }^{113}$ (1994), AQRABAWI ${ }^{10}$ (2000) e VINHOLES ${ }^{114}$ (2000), parece ser uma boa maneira de se analisar a infiltração marginal ocorrida na interface entre o material e a cavidade dentinária para o trabalho em questão, devido à espessura do assoalho da câmara pulpar ser pequena, e conseqüentemente a profundidade da perfuração, também.

Apoiados nos trabalhos de ALHADAINY; HIMEL ${ }^{09}$ (1993), ALHADAINY; HIMEL ${ }^{07}$ (1994), CHAU et al. ${ }^{30}$ (1997), ALHADAINY; ABDALLA ${ }^{06}$ (1998) e MITTAL; CHANDRA; CHANDRA ${ }^{68}$ (1999) as leituras das infiltrações foram realizadas, tomando como referência a pigmentação pelo corante na interface material-parede dentinária, a partir da porção mais apical da perfuração, até a porção mais coronal. Nos grupos em que se utilizou a matriz de gesso Paris, a infiltração foi medida a partir da porção mais apical do material obturador até a porção mais coronal, excluindo totalmente a infiltração ocorrida na matriz, embora, inicialmente se pudesse pensar que a mesma pudesse servir, também, como material selador, o que, comprovadamente, não ocorreu, conforme observado por CHAU et al. ${ }^{30}$ (1997) e pelos próprios resultados observados. 
Optou-se pelo uso de 3 examinadores, que atuavam independentemente um do outro, gerando uma média que acredita-se ser a expressão real daquilo que realmente ocorreu na interface dentina/material, e que seria, certamente, duvidoso ante a observação de um único examinador.

O emprego do microscópio eletrônico de varredura, teve como finalidade observar diretamente os espécimes quanto à adaptação marginal dos materiais na interface material/parede dentinária da perfuração. Segundo STABHOLTZ et al. $^{96}$ (1985) a adaptação marginal é um método indireto de verificar a capacidade de selamento de materiais obturadores, e foi utilizada por AUN et al. ${ }^{12}$ (1989), BRAMANTE et al. ${ }^{25}$ (1990), BERNARDINELI ${ }^{21}$ (1993), TORABINEJAD et al. $^{105}$ (1995), FITZPATRICK; STEIMAN ${ }^{40}$ (1997), TANOMARU FILHO; MENDONÇA; TANOMARU $^{99}$ (2001) e também por KUBO ${ }^{59}$ (2001). Todos estes autores, levantam a hipótese de que pode existir uma relação entre a infiltração marginal e o desajuste do material obturador, embora não existam fortes evidências do fato, e sim, apenas incertezas.

Para observação da adaptação marginal dos materiais em teste e da matriz de gesso Paris, foi utilizado o aumento de 50X para obtenção das fotomicrografias em visão panorâmica e de 200X nos locais onde se encontrou espaços ou fendas entre a parede dentinária da perfuração e o material obturador. 


\subsection{Discussão dos resultados}

$\mathrm{Na}$ análise da Tabela 3 e da Figura 22, que contêm as médias dos escores das infiltrações marginais do corante rhodamine B nos espécimes preenchidos somente com os cimentos, verifica-se que os grupos do MBP-c e do Super-EBA, apresentaram as menores médias de penetração de corante 0,4 e 1,1 respectivamente, enquanto os grupos do MTA - Angelus e do ProRoot - MTA, apresentaram média de 2,7.

Sob avaliação pelo teste de Kruskal-Wallis $(p<0,001)$, detectou-se diferença estatisticamente significante, e, quando submetidos ao teste de Dunn, na comparação dos grupos dois a dois (Tabela 6), observa-se que os espécimes preenchidos com o MBP-c, e Super-EBA mostraram diferença estatisticamente significante quando comparados ao MTA - Angelus e ao ProRoot - MTA..

BRANDÃO ${ }^{28}$ (1999) estudou as propriedades físico-químicas do cimento MBP, porém na consistência para ser utilizado em obturação de canais radiculares. Concluiu, em relação à infiltração marginal, que tal cimento apresentou pequeníssimas médias de infiltração marginal, possibilitando um adequado selamento apical. Os resultados observados neste trabalho referentes ao MBP-c, estão de acordo com PAVAN $^{81}$ (1999) que comparou a infiltração marginal em obturações retrógradas realizadas com um cimento epóxico experimental (MBP-c) e o Super-EBA. Os resultados mostraram menores médias de infiltrações nos dentes obturados com o cimento experimental. Diga-se que o cimento epóxico experimental testado por PAVAN ${ }^{81}$ era composto por uma mistura pasta/líquido. Já o MBP-c, aqui avaliado é apresentado na forma de duas pastas. 
Em relação ao Super-EBA os resultados observados neste trabalho estão de acordo com os de MOLONEY; FEIK; ELLENDER ${ }^{69}$ (1993) e YAMASHITA et al. $^{121}$ (1999), que obtiveram resultados satisfatórios com a utilização desse cimento.

No que concerne à capacidade de selamento do agregado de trióxido mineral (ProRoot - MTA e MTA - Angelus) LEE; MONSEF; TORANINEJAD ${ }^{62}$ (1993), TORABINEJAD et al. $^{106}$ (1994), AQRABAWI ${ }^{10}$ (2000) encontraram resultados opostos aos encontrados neste trabalho, pois não visualizaram infiltração alguma. Há que ressaltar que esses autores utilizaram como marcador o azul de metileno, que segundo WU; KONTAKIOTIS; WESSELINK ${ }^{118}$ (1998) e MORAES et al. $^{70}$ (2000) pode ter sido descolorido, levando ao registro errôneo de um resultado falso negativo.

Corroborando com os resultados deste trabalho, SILVA NETO et al. ${ }^{91}$ (2001) não encontraram diferenças estatisticamente significantes entre as infiltrações marginais do corante rhodamine B em obturações retrógradas realizadas com MTA - Angelus, ProRoot - MTA e Super-EBA. Já, TORABINEJAD; WATSON; PITT FORD ${ }^{113}$ (1993) encontraram menores médias de infiltração do corante rhodamine B para o MTA quando comparadas ao Super-EBA. Assim, KUBO ${ }^{59}$ (2001) também acusou baixos níveis de infiltração no MTA, quando utilizou o corante rhodamine B, porém, é importante salientar que o referido autor esperou 24 horas para imersão dos espécimes no corante. É sabido que esse tipo de material sofre certa expansão após seu endurecimento e, conseqüentemente tem sua capacidade seladora melhorada (TORABINEJAD et al. ${ }^{105}$ 1995, TORABINEJAD et al. ${ }^{109}$ 1995). 
Segundo experimentos de TORABINEJAD et al. ${ }^{109}$ (1995) o MTA apresenta uma desvantagem em relação ao Super-EBA. Seu tempo de presa é de 2 horas e 45 minutos, enquanto que o do Super-EBA faz-se ao final de 9 minutos. $O$ fabricante do MTA - Angelus, informa que o tempo de presa inicial é de 2 horas e 29 minutos, e o final de 3 horas e 37 minutos. O cimento MBP-c, segundo seu idealizador, apresenta o tempo de presa de 4 horas*. Por outro lado, não se pode afirmar que o tempo de presa influenciou nos resultados, visto que o cimento com maior tempo de presa alcançou os melhores resultados. Talvez, para determinados procedimentos como uma obturação retrógrada o maior tempo de presa seja uma desvantagem clínica em relação ao acabamento externo do material; biologicamente permanece a dúvida.

As desvantagens referentes ao Super-EBA foram citadas por TORABINEJAD; WATSON; PITT FORD ${ }^{113}$ (1993) como sendo um material sensível à umidade, irritante dos tecidos vitais, solúvel e de difícil manipulação clínica. De fato foi observada certa dificuldade de manipulação do material.

Segundo relatos de LEE; MONSEF; TORABINEJAD ${ }^{62}$ (1993) é possível que a umidade presente no local da perfuração reduza a capacidade de selamento dos materiais. Considerando o fato de que os locais das perfurações são comumente contaminados com sangue ou fluídos teciduais, materiais à base de óxido de zinco e eugenol podem não ser convenientes para utilização em perfurações radiculares. Entretanto, os resultados deste trabalho mostram que o cimento Super-EBA, foi superior em relação ao ProRoot - MTA e ao MTA - Angelus, no tocante ao selamento marginal. 
TORABINEJAD et al. ${ }^{106}$ (1994) demonstraram que o MTA infiltrou significantemente menos que o Super-EBA, tanto na presença como na ausência de sangue. Afirmaram, ainda, que o MTA pode ser utilizado em meio úmido, devido às suas características hidrofílicas, sendo a umidade a responsável pela ativação da reação química de endurecimento do material. (LEE; MONSEF; TORABINEJAD $\left.{ }^{62}, 1993\right)$.

$\mathrm{Na}$ análise sob M.E.V. da interface dos materiais com as bordas da perfuração dos espécimes, pôde-se verificar a presença de fendas marginais quer a 50X ou a 200X (Figuras 13 a 17), principalmente nos espécimes obturados com o ProRoot - MTA e com o MTA - Angelus. Tais resultados são discordantes dos observados por TORABINEJAD et al. $^{105}$ (1995), que verificaram a adaptação marginal do MTA e do Super-EBA, encontrando resultados favoráveis estatisticamente ao MTA, devido a uma fina camada do material na junção com a dentina e à possibilidade de expansão do mesmo após seu endurecimento. Em relação à adaptação marginal do Super-EBA, os resultados aqui observados estão corroborando com BERNARDINELI ${ }^{21}$ (1993), FITZPATRICK; STEIMAN ${ }^{40}$ (1997) que encontraram boa adaptação deste cimento às paredes das cavidades utilizandoo em obturações retrógradas.

STABHOLZ et al. ${ }^{96}$ (1985) verificaram, por meio da observação direta dos espécimes, a presença de microfraturas na superfície de secção apical, que aumentavam a fenda marginal na interface material-preparo cavitário, embora não fosse verificada a presença das mesmas microfraturas e fendas marginais em suas réplicas correspondentes. Tal fato sugere a possibilidade de que as fendas marginais localizadas entre as microfraturas dentinárias possam inexistir, embora tal 
afirmação não possa ser confirmada, pois no presente estudo não foi realizada a confecção de réplicas para observação dos espécimes em M.E.V..

Entretanto, para TORABINEJAD et al. ${ }^{105}$ (1995), o preparo dos espécimes (desde a obtenção até a secagem para permitir a metalização) para o exame em M.E.V. promove a introdução de inúmeros artefatos de técnica que são caracterizados pela observação de microfraturas. Para tanto, os autores sugeriram a análise dos espécimes e de suas réplicas.

O MBP-c mostrou as melhores adaptações marginais às paredes dentinárias das perfurações entre os quatro materiais testados. Sendo este um cimento a base de resina epóxi, e pelo fato de sua fórmula ser derivada da base química do cimento $\mathrm{AH} 26$, podemos destacar resultados semelhantes encontrados por TANOMARU FILHO; MENDONÇA; TANOMARU ${ }^{99}$ (2001) que verificaram excelentes adaptações marginais, em perfurações radiculares laterais, utilizando o Sealer26 (mesma base química do AH26).

Após a análise e a interpretação das fotomicrografias, foram encontradas melhores adaptações marginais nos espécimes preenchidos com o MBP-c e com o Super-EBA, e, resultados inferiores e semelhantes, em relação ao ProRoot - MTA e ao MTA - Angelus, que apresentaram adaptação marginal deficiente.

Referindo-se a todos os dados discutidos, quer seja à adaptação marginal ou mesmo à infiltração marginal, uma outra proposta definida quanto ao trabalho, foi verificar a possível relação entre essas duas variáveis, ou seja, checar se realmente maiores desadaptações do material às paredes dentinárias da perfuração correspondiam a maiores infiltrações marginais. 
De fato, tal correlação ocorreu pois foram encontrados os piores resultados, nos testes de infiltração marginal e adaptação marginal, nos grupos onde as perfurações foram preenchidas com o ProRoot - MTA e MTA - Angelus.

Estas observações estão de acordo com trabalhos de STABHOLTZ et al. $^{96}$ (1985), BERNARDINELI ${ }^{21}$ (1993) onde afirmaram que melhores ou piores adaptações resultavam em melhores ou piores selamentos, respectivamente.

Outra proposta mencionada em nosso trabalho, foi de avaliar o extravasamento dos materiais para fora da cavidade da perfuração. Após a obturação dos espécimes, comprovou-se que todos apresentavam extravasamento, quando da utilização isolada do material. Contudo, na presença da matriz de gesso Paris, não foi verificado a ocorrência de extravasamentos dos cimentos.

Analisando a Tabela 5 , pode-se verificar por meio do teste de MannWhitney $(p<0,05)$, que houve diferença estatisticamente significante, na infiltração marginal dos cimentos em função da presença da matriz de gesso Paris para o Super-EBA e o MBP-c, sendo que na presença da matriz a infiltração foi maior.

$\mathrm{Na}$ análise da Tabela 4 e da Figura 23, que contêm as médias dos escores das infiltrações marginais do corante rhodamine B nos espécimes onde foi utilizada a matriz de gesso Paris, associada aos cimentos, verifica-se que o grupo do MBP-c, apresentou as menores médias de penetração de corante 1,0. O Super-EBA apresentou média de 2,1, o grupo do MTA - Angelus 2,2 e o grupo do ProRoot MTA apresentou média de 2,4.

Sob avaliação pelo teste de Kruskal-Wallis $(p<0,05)$, detectou-se diferença estatisticamente significante, e, quando submetidos ao teste de Dunn, na comparação dos grupos dois a dois (Tabela 7), observa-se que os espécimes 
preenchidos com o MBP-c, mostraram diferença estatisticamente significante quando comparados ao MTA - Angelus e ao ProRoot - MTA.

No que diz respeito ao extravasamento dos materiais, quando da presença da matriz de gesso Paris, os resultados deste trabalho encontram apoio nas pesquisas de ALHADAINY; HIMEL $^{07}$ (1994), HIMEL; ALHADAINY47 (1995), ALHADAINY; ABDALLA ${ }^{06}$ (1998), MITTAL; CHANDRA; CHANDRA ${ }^{68}$ (1999) que exaltaram a eficiência da matriz de gesso Paris, no controle do extravasamento dos materiais, favorecendo o prognóstico dos casos de perfurações radiculares.

Um achado de ALHADAINY; HIMEL ${ }^{07}$ (1994), digno de importante registro, pôde ser comprovado, pois se refere ao aumento da infiltração marginal, quando da presença da matriz de gesso Paris. Entretanto, HIMEL; ALHADAINY47 (1995), ALHADAINY; ABDALLA ${ }^{06}$ (1998), MITTAL; CHANDRA; CHANDRA ${ }^{68}$ (1999) justificam a maior extensão de infiltração, pela presença de fragmentos da matriz de gesso Paris, entre o material obturador e as paredes dentinárias das perfurações. A propósito, vale lembrar, que o material utilizado nos trabalhos mencionados anteriormente era diferente dos utilizados neste trabalho.

A respeito do exposto acima, CHAU et al. ${ }^{30}$ (1997) propuseram a remoção dos fragmentos do material utilizado para confecção da matriz (cimento de fosfato de cálcio), e afirmaram que tal manobra aumentou à capacidade de selamento dos materiais utilizados no preenchimento das perfurações. No entanto, neste trabalho, tal fato não foi verificado.

Em relação à adaptação marginal dos espécimes, considerando a matriz de gesso (Figura 17), pôde-se verificar em M.E.V. que, embora o gesso Paris, em alguns casos, tenha sofrido um pequeno extravasamento, o seu comportamento pode ser considerado aceitável, pois sua utilização teve como objetivo, funcionar 
como anteparo, evitando o extravasamento dos materiais seladores. No entanto, vale lembrar, que além de ser biocompatível, clinicamente ele é totalmente reabsorvido pelas defesas orgânicas, conforme trabalho de $\mathbf{B A H N}^{15}$ (1966), daí ser de somenos importância o extravasamento observado. 


\subsection{Considerações gerais}

Nos trabalhos realizados in vitro, procura-se introduzir todo o necessário para que a situação clínica seja reproduzida. Nem sempre se consegue. Portanto, os resultados observados neste tipo de trabalho podem não exprimir exatamente o que acontece na intimidade dos tecidos, onde os materiais podem se comportar diferentemente.

Assim, o agregado de trióxido mineral (MTA) apresenta excelentes resultados clínicos/biológicos. A infiltração marginal maior observada nos seus representantes (MTA - Angelus e ProRoot - MTA) não é suficiente, nem pode condenar o uso desse material. Sua característica de endurecimento é especial, necessitando de umidade, o que provoca uma expansão do material melhorando o selamento. A rhodamine B é um excelente marcador e pode ter se infiltrado nas primeiras horas de imersão dos espécimes, antes da provável expansão do material.

O cimento MBP-c apresentou as menores médias de infiltração (com ou sem a matriz de gesso Paris), possivelmente por ser um cimento resinoso e apresentar alta adesividade e nenhuma contração. O Super-EBA situou-se em uma posição intermediária em relação aos outros materiais.

O significado clínico dos estudos de adaptação marginal, relacionados com a infiltração de corantes é, ainda, indefinido. É praticamente impossível determinar o quanto de percolação poderia resultar em fracasso já que, na maioria dos casos, a quantidade de infiltração parece ser clinicamente insignificante em vista dos fenômenos biológicos existentes nos casos de tratamento de perfurações radiculares. 
É importante ressaltar novamente, que os resultados desses testes não podem, por si só, recomendar ou condenar o uso de algum material. Inclusive, cada material tem as suas características físicas e biológicas e o profissional deve ter o discernimento de indicar o melhor para aquelas condições específicas.

Conscientes das limitações de todo experimento in vitro, e das possíveis correlações clínicas, visualiza-se a necessidade de ensaios de compatibilidade biológica, para avaliar o comportamento dos tecidos de suporte, frente aos materiais seladores de perfurações de furca utilizados neste trabalho, complementando, assim, os resultados obtidos. 


\section{CONCLUSÕES}

De acordo com a metodologia utilizada neste trabalho e considerando seus resultados e a discussão pertinente, são válidas as seguintes conclusões:

7.1 - Quando utilizado isoladamente, o cimento MBP-c apresentou os menores índices de infiltração marginal, seguido pelo Super-EBA, havendo diferença estatística entre esses e os cimentos ProRoot - MTA e MTA - Angelus $(p<0,001)$;

7.2 - Na presença da matriz de gesso Paris, o cimento MBP-c apresentou os menores índices de infiltração marginal, havendo diferença estatística entre esse e os cimentos ProRoot - MTA e MTA - Angelus $(p<0,05)$;

7.3 - A matriz de gesso Paris influenciou negativamente o selamento marginal dos cimentos MBP-c e Super-EBA, inclusive, com diferenciação estatística $(p<0,05)$;

7.4 - A utilização da matriz de gesso Paris foi efetiva em evitar o extravasamento dos materiais seladores;

7.5 - Foi observada uma relação direta entre a adaptação marginal e a capacidade de selamento. 


\section{REFERÊNCIAS BIBLIOGRÁFICAS*}

01 ABEDI, H.R.; INGLE, J.I. Mineral trioxide aggregate: A review of a new cement. J. Calif. dent. Ass., v.23, n.12, p.36-9, Dec. 1995.

02 ADAMO, H.L. et al. A comparison of MTA, Super-EBA, composite and amalgam as root-end filling material using a bacterial microleakage model. Int. Endod. J., v.32, n.3, p. 197-203, 1999.

03 AGUIRRE, R.; ELDEEB, M.E.; ELDEEB, M.E. Evaluation of the repair of mechanical furcation perforation using amalgam, gutta-percha, or indium foil. J. Endod., v.12,n.6, p.249-56, June. 1986.

04 AL-GHAMDI, A.; WENNBERG, A. Testing of sealing ability of endodontic filling materials. Endod. dent. Traumat, v.10, n.6, p.249-55, Dec. 1994.

05 ALHADAINY, H.A. Root perforations - A review of literature. Oral Surg., v.78, n.3, p.368-74, Sept. 1994.

06 ALHADAINY, H.A.; ABDALLA, A.I. Artificial floor technique used for the repair of furcation perforations: a microleakage study. J. Endod., v.24, n.1, p.33-5, Jan. 1998.

07 ALHADAINY, H.A.; HIMEL, V.T. An in vitro evaluation of plaster of Paris Barriers used under amalgam and glass ionomer to repair furcation perforations. J. Endod., v.20, n.9, p.449-52, Sept. 1994. 
ALHADAINY, H.A.; HIMEL, V.T. Comparative study of the sealing ability of light-cured versus chemically cured materials placed into furcation perforations. Oral Surg., v.76, n.3, p.338-42, Sept. 1993.

09 ALHADAINY, H.A.; HIMEL, V.T. Evaluation of sealing of amalgam, Cavit, and glass ionômero cement in the repair of furcation perforations. Oral Surg., v.75, n.3, p.362-66, Mar. 1993.

10 AQRABAWI, J. Sealing ability of amalgam, Super-EBA cement, and MTA when used as retrograde filling materials. Brit. dent. J., v.188, n.5, p.266-68, Mar. 2000.

11 ARENS, D.E.; TORABINEJAD, M. Repair of furcal perforations with mineral trioxide aggregate - two case reports. Oral Surg., v.82, n.1, p.84-8, July. 1996.

12 AUN, C.E. et al. Estudo comparativo entre três materiais utilizados no preenchimento das perfurações provocadas durante o preparo para retentor intra-radicular. Rev. Fac. Odont. F.Z.L., v.1, n.1, p.7-20, jan./jun. 1989.

13 AUN, C.E.; GAVINI, G.; FACHIN, E.V.F. Perfurações endodônticos: existe solução?. In: TODESCAN, F.F.; BOTTINO, M.A. Atualização na clínica odontológica - a prática da clínica geral. São Paulo: Artes Médicas, 1996. p.211-46. 
14 AUSLANDER, W.P.; WEINBERG, G. Anatomic repair of internal perforation with HTR grafting material. N. Y. St. dent. J., v.39, n.10, p.454-7, Dec. 1969.

15 BAHN, S.L. Plaster: A bone substitute. Oral Surg., v.21, n.5, p.672-9, May. 1966.

16 BAKLAND, L.K. Endodontic mishaps: perforation. Calif. Dent. Assoc., v.19, n.10, p.41-8, Oct. 1991.

17 BALLA, R. et al. Histological study of furcation perforation treated with tricalcium phosphate, hidroxylapatite, amalgam, and Life. J. Endod., v.17, n.5, p.234-8, May. 1992.

18 BATES, C.F.; CARNES, D.L.; del RIO, C.E. Longitudinal sealing ability of mineral trioxide aggregate as a root-end filling material. J. Endod., v.22, n.11, p.575-8, Nov. 1996.

BENATTI NETO, C. Tratamento de perfurações radiculares com pastas de hidróxido de cálcio e iodofórmio. Emprego de diferentes veículos: estudo histológico em dentes de cães. Bauru, 1984. 109p. Tese (Doutorado) - Faculdade de Odontologia de Bauru, Universidade de São Paulo.

20 BENENATI, F.W. et al. Recall evaluation of iatrogenic root perforations repaired with amalgam and gutta-percha. J. Endod., v.12, n.4, p.161-6, Apr. 1986. 
21 BERNARDINELI, N. Obturação retrógrada - Avaliação da adaptação às paredes das cavidades e infiltração marginal, em função dos materiais obturadores e de agentes de limpeza. Bauru, 1993. 168p. Tese (Livre-Docência) - Faculdade de Odontologia de Bauru, Universidade de São Paulo.

22 BOGAERTS, P. Treatment of root perforations with calcium hydroxide and Super-EBA cement: a clinical report. Int. Endod. J., v.30, n.3, p.210-19, July. 1997.

23 BOHSALI, K. et al. Sealing ability of Super-EBA and Dyract as root-end fillings: a study in vitro. Int. Endod. J., v.31, n.5, p.338-42, May. 1998.

24 BONDRA, D.L. et al. Leakage in vitro with IRM, high cooper amalgam, and EBA cement as retrofilling materials. J. Endod., v.15, n.4, p.15760, Apr. 1989.

25 BRAMANTE, C.M. et al. Análise através da microscopia eletrônica de varredura de alguns materiais utilizados em obturação retrógrada. Rev. bras. Odont., v.47, n.6, p.29-34, nov./dez., 1990.

26 BRAMANTE, C.M. Tratamento de perfurações radiculares com pasta de hidróxido de cálcio e iodofórmio - influência do período de troca - Estudo histológico em dentes de cães. Bauru, 1980. 112p. Tese (Livre-Docência) - Faculdade de Odontologia de Bauru, Universidade de São Paulo. 
27 BRAMANTE, C.M.; BERBERT, A. Root perforations dressed with calcium hydroxide or zinc oxide and eugenol. J. Endod., v.13, n.8, p.392-5, Aug. 1987.

28 BRANDÃO, C.G. Propriedades físico-químicas dos cimentos endodônticos resinosos Sealer 26, e dos experimentais, Sealer plus e MBP, comparadas às do óxido de zinco e eugenol. Bauru, 1999. 150p. Dissertação (Mestrado) - Faculdade de Odontologia de Bauru, Universidade de São Paulo.

29 CATTONI, M. Common failures in endodontics and their correction. Dent. Clin. N. Amer., n.7, p.383-99, July. 1963.

30 CHAU, J.Y.M. et al. An in vitro study of furcation perforation repair using calcium phosphate cement. J. Endod., v.23, n.9, p.588-92, Sept. 1997

31 CHRISTEN, A.G.; MITCHELL, D.F. A fluorescent method for demonstrating leakage around dental restorations. J. dent. Res., v.45, n.5, p.1485-92, Oct. 1966.

32 DALÇÓQUIO, C. et al. Selamento apical após retrobturações com MTA, IRM, ionômero de vidro e cianoacrilato. Rev. Ass. paul. cirurg. Dent., v.55, n.3, p.194-8, mai./jun. 2001. 
33 DAZEY, S.; SENIA, S. An in vitro comparison of sealing ability of materials placed in lateral root perforations. J. Endod.,v.16, n.1, p.19-23, Jan. 1990.

34 DELIVANIS, P.D.; CHAPMAN, K.A. Comparison and reliability of techniques for measuring leakage and marginal penetration. Oral Surg., v.53, n.4, p.410-6, Apr. 1982.

35 DELIVANIS, P.D.; GOERIG, A.C. Repair of perforations. Quintessence Int., v.12, n.9, p.985-92, Sept. 1981.

36 DOW, P.R.; INGLE, J.I. Isotope determination of root canal failure. Oral Surg., v.8, n.1100-4, Sept. 1955.

37 ELDEEB, M.E. et al. An evaluation of the use of amalgam, Cavit, and calcium hydroxide in the repair of furcation perforations. J. Endod., v.8, n.10, p.459-66, Oct. 1982.

38 ESTRELA, C. et al. Antimicrobial and chemical study of MTA, Portland cement, calcium hydroxide paste, Sealapex and Dycal. Braz. dent. J., v.11, n.1, p.3-9, Jan. 2000.

39 FISCHER, E.J.; ARENS, D.E.; MILLER, C.H. Bacterial leakage of mineral trioxide aggregate as compared with zinc-free amalgam, intermediate restorative material, and Super-EBA as a root-end filling material. J. Endod., v.24, n.3, p.176-9, Mar. 1998. 
40 FITZPATRICK, E.L.; STEIMAN, H.R. Scanning electron microscopic evaluation of finishing techniques on IRM and EBA retrofillings. J. Endod., v.23, n.7, p.423-7, July. 1997.

41 FOGEL, H.M.; PEIKOFF, M.D. Microleakage of root-end filling materials. J. Endod., v.27, n.7, p.456-8, July. 2001.

42 FRANK, A.L. Perforations. In. Clinical and surgical endodontics: concepts in practice. Philadelphia, Lippincott, 1983. p. 154-62.

43 FUSS, Z.; TROPE, M. Root perforations: classification and treatment choices based on prognostic factors. Endod. dent. Traumat., v.12, n.6, p.255-64, Dec. 1996.

44 FUSS, Z.; SJAKIS, S.; TAGGER, M. Periodontal response to glass ionômero cement in treatment of furcation perforations in dogs. J. dent. Res., v.71, n.4, p.1031, Apr. 1992.

45 HAMAOKA, L. Avaliação in vitro da permeabilidade dentinária radicular, tendo como fonte de variação três diferentes tipos de corantes. São Paulo, 1995. 41p. Dissertação (Mestrado) Faculdade de Odontologia, Universidade de São Paulo.

46 HARTWELL, G.R.; ENGLAND, M.C. Healing of furcation perforation in primate teeth repair with decalcified freeze-dried bone. J. Endod., v.19, n.7, p.357-61, July. 1993. 
47 HIMEL, V.T.; ALHADAINY, H.A. Effect of dentin preparation and acid etching on the sealing ability of glass ionomer and composite resin when used to repair furcation perforations over plaster of Paris barriers. J. Endod., v.21, n.3, p.142-5, Mar. 1995.

48 HIMEL, V.T.; BRADY JR., J.; WEIR JR., J. Evaluation of repair of mechanical perforations of the pulp chamber floor using biodegradable tricalcium phosphate or calcium hydroxide. J. Endod., v.11, n.4, p.161-5, Apr. 1985.

49 HOLLAND, $R$. et al. Mineral trioxide aggregate repair of lateral root perforations. J. Endod., v.27, n.4, p.281-4, Apr. 2001.

50 HOLLAND, R. et al. Reaction of dog's teeth to root canal filling with mineral trioxide aggregate or a glass ionomer sealer. J. Endod., v.25, n.11, p.728-30, Nov. 1999.

51 HOLLAND, R. et al. Reaction of rat connective tissue to implanted dentin tube filled with mineral trioxide aggregate, Portland cement or calcium hydroxide. Braz. dent. J., v.12, n.1, p.3-8, Jan. 2001.

52 HOLT, G.M.; DUMSHA, T.C. Leakage of amalgam, composite, and Super-EBA, compared with a new retrofill material: bone cement. J. Endod., v.26, n.1, p.29-31, Jan. 2000.

53 INGLE, J.I. Exitos y fracasos em endodoncia. Rev. Ass. odont. argent., v.50, n.2, p.67-74, Feb. 1962. 
54 JEW, R.C.K. et al. A histologic evaluation of periodontal tissues adjacent to root perforations filled with Cavit. Oral Surg., v.54, n.1, p.124-35. July. 1982.

55 KARAGÖZ-KÜÇÜKAY, I.; KÜÇÜKAY, S.; BAYIRLI, G. Factors affecting apical leakage assessment. J. Endod., v.19, n.7, p.362-5, July 1993.

56 KETTERING, J.D.; TORABINEJAD, M. Investigation of mutagenicity of mineral trioxide aggregate and other commonly used root-end filling materials. J. Endod., v.21, n.11, p.537-42, Nov. 1995.

57 KONTAKIOTIS, E.G.; WU, M.-K.; WESSELINK, P.R. Effect of calcium hydroxide dressing on seal permanent root filling. Endod. dent. Traumat., v.13, n.6, p.281-4, Dec. 1997.

58 KOTON, D. A root perforations and treatment. J. dent. Ass. S. Afr., v.52, n.5, p.366-7, May. 1997.

$59 \mathrm{KUBO}, \mathrm{C} . \mathrm{H}$. Avaliação do selamento de ápices radiculares tratados com diferentes agentes desmineralizantes e retrobturados com ProRoot - MTA, mediante infiltração marginal por corante. São José dos Campos, 2001. 160p. Dissertação (Mestrado) - Faculdade de Odontologia de São José dos Campos, Universidade Estadual Paulista.

60 KVINNSLAND, I. et al. A clinical and roentgenological study of 55 cases of root perforations. Int. Endod. J., v.22, n.2, p.75-84, Mar. 1989. 
61 LANTZ, B.; PERSSON, P.A. Periodontal tissue reactions after root perforations in dog's teeth - a histologic study. Odont. T., v.75, n.3, p.209-20, June. 1967.

62 LEE, S.J.; MONSEF, M.; TORABINEJAD, M. Sealing ability of a mineral trioxide aggregate for repair of lateral root perforations. J. Endod., v.19, n.11, p.541-44, Nov. 1993.

63 LEMON, R.R. Nonsurgical repair of perforations defects: internal matrix concept. Dent. Clin. N. Amer., v.36, n.2, p.439-57, Apr. 1992.

64 MACHADO, M.E.L.; FERNANDES, K.P.S.Tratamento de perfurações de furca - materiais e selamento. J. bras. Odontol. clin., v.1, n.1, p.4954, jan./fev. 1997.

65 MANNOCCI, F.; VICHI, A.; FERRARI, M. Sealing ability of several restorative materials used for repair of lateral root perforations. J. Endod., v.23, n.10, p.639-41, Oct. 1997.

66 MARTOS, J.; SILVEIRA, L.F.M. Relação do assoalho da câmara pulpar com o limite amelo-cementário e a furcação. J. bras. Odontol. clin., v.30, n.15, p.63-6, março.1999.

67 MEISTER, F. et al. Endodontic perforations which resulted in alveolar bone loss. Oral Surg., v.47, n.5, p.463-70, May. 1979. 
68

MITTAL, M.; CHANDRA, S.; CHANDRA, S. An evaluation of plaster of Paris barriers used under various materials to repair furcation perforations (in vitro study). J. Endod., v.25, n.5, p.385-88, May. 1999.

69 MOLONEY, L.G.; FEIK, S.A.; ELLENDER, G. Sealing ability of three materials used to repair lateral root perforations. J. Endod., v.19, n.3, p.59-62, Feb. 1993.

70 MORAES, I.G. et al. Influência do hidróxido de cálcio e do EDTA na marcação da infiltração marginal de azul de metileno em obturações de canais radiculares. Rev. FOB, v.8, n.1/2, p.37-44, jan.jun. 2000.

71 MORAES, I.G. Infiltração marginal nas obturações de canais radiculares em função de agentes irrigadores e cimentos obturadores. Bauru, 1981. 114p. Dissertação (Mestrado) Faculdade de Odontologia de Bauru, Universidade de São Paulo.

72 MORAES, I.G. Propriedades físicas de cimentos epóxicos experimentais para obturação de canais radiculares. Bauru, 1984. 149p. Tese (Doutorado) - Faculdade de Odontologia de Bauru, Universidade de São Paulo.

73 NAKATA, T.T.; BAE, K.S.; BAUMGARTNER, J.C. Perforation repair comparing mineral trioxide aggregate and amalgam using an anaerobic bacterial leakage model. J. Endod., v.24, n.3, p.184-6, Mar. 1998. 
74 NICHOLLS, E. Treatment of traumatic perforations of the pulp cavity. Oral Surg., v.15, n.5, p.603-12, May. 1962.

75 NUNES, E. Influência de hidróxido de cálcio e do EDTA na marcação da infiltração marginal de azul de metileno em obturação de canais radiculares. Bauru, 1999. 126p. Tese (Doutorado) Faculdade de Odontologia de Bauru, Universidade de São Paulo.

76 O'CONNOR, R.P.; HUTTER, J.W.; ROAHEN, J.O. Leakage of amalgam and Super-EBA root-end fillings using two preparation techniques and surgical microscopy. J. Endod., v.21, n.2, p.74-8, Feb. 1995.

77 OSORIO, R.M. et al. Citotoxicity of endodontic materials. J. Endod., v.24, n.6, p.91-6, Feb. 1998.

78 OSWALD, R.J. Procedural accidents and their repair. Dent. Clin. N. Amer., v.23, n.4, p.593-616, Oct. 1979.

79 OYNICK, J.; OYNICK, T. A study of a new material for retrograde fillings. J. Endod., v.4, n.7, p.203-6, July. 1978.

80 OYNICK, J.; OYNICK, T. Treatment of endodontic perforations. J. Endod., v.11, n.4, p.191-2, Apr. 1985. 
81 PAVAN, N.N.O. Análise da infiltração marginal em obturações retrógradas realizadas com polímero de mamona, epóxico experimental, cimento de óxido de zinco eugenol reforçado (Super-EBA) e ionômero de vidro (FUJI II LC). Bauru, 1999. 99p. Dissertação (Mestrado) - Faculdade de Odontologia de Bauru, Universidade de São Paulo.

82 PETERSSON, K.; HASSELGREN, G.; TRONSTAD, L. Endodontic treatment of experimental root perforations in dog teeth. Endod. dent. Traumat., v.1, n.1, p.22-8, Feb. 1985.

83 PITT FORD, T.R. et al. Using mineral trioxide aggregate as a pulpcapping material. J. Amer. dent. Ass., v.127, n.10, p.1491-4, Oct. 1996.

84 PITT FORD, T.R. Use of mineral trioxide aggregate for repair of furcal perforations. Oral Surg., v.79, n.6, p.756-62, June. 1995.

85 POLLARD, B.K.; WELLER, R.N.; KULILD, J.C. A standardized technique for linear dye leakage studies: immediate versus delayed immersion times. Int. Endod. J., v.23, n.5, p. 250-3, Sept. 1990.

86 PRO ROOT: MTA (Mineral Trioxide Aggregate). Root canal repair material system - Instructional CD. Dentsly Tulsa Dental. USA, 1998. 
87 SCHEERER, S.Q.; STEIMAN, H.R.; COHEN, J. A comparative evaluation of three root-end filling materials: an in vitro leakage study using Prevotella nigrescens. J. Endod., v.27, n.1, p.40-2, Jan. 2001.

88 SELTZER, S. et al. Endodontic failures: an analysis based on clinical radiographic and histologic findings. Oral Surg., V.23, n.4, p.500-30, Apr. 1967.

89 SELTZER; S.; SINAI, I.; AUGUST, D. Periodontal effects of root perforations before and during endodontic procedures. J. dent. Res., v.49, n.2, p.332-9, Mar./Apr. 1970.

90 SHIMABUKO, D.M. Avaliação “in vitro” do selamento marginal obtido quando do uso de associações de materiais no tratamento de perfurações de furca em molares humanos. São Paulo, 1997. 79p. Dissertação (Mestrado) - Faculdade de Odontologia, Universidade de São Paulo.

91 SILVA NETO, U.X. da. et al. Avaliação do selamento apical de obturações retrógradas realizadas com MTA e Super-EBA. In: CONGRESSO INTERNACIONAL DE ODONTOLOGIA DO PARANÁ, 6., ANAIS. Curitiba, 2001. p.28.

92 SINAI, I.H. Endodontic perforations: their prognosis and treatment. $\mathbf{J}$. Amer. dent. Ass., v.95, n.1, p.90-5, July. 1977. 
93 SLUIK, S.R.; MOON, P.C.; HARTWELL, G.R. Evaluation of setting properties and retention characteristics of mineral trioxide aggregate when used as furcation perforation repair material. J. Endod., v.24, n.11, p.768-71, Nov. 1998.

94 SOARES, I.M.L. Comportamento dos tecidos periodontais frente às perfurações radiculares tratadas com hidróxido de cálcio, polímero H.T.R. - 40 e hidroxiapatita. (Avaliação histológica em dentes de cão). Bauru, 1992. 115p. Tese (Doutorado) - Faculdade de Odontologia de Bauru, Universidade de São Paulo.

95 SPÅNGBERG, L.S.W.; ACIERNO, T.G.; CHA, B.Y. Influence of entrapped air on the accuracy of leakage studies using dye penetration methods. J. Endod., v.15, n.11, p.548-51, Nov. 1989.

96 STABHOLTZ, A. et al. Marginal adaptation of retrograde fillings and its correlation with sealability. J. Endod., v.11, n.5, p.218-23, May. 1985.

97 STARKEY, D.L.; ANDERSON, R.W.; PASHLEY, D.H. An evaluation of the effect of methylene blue dye $\mathrm{pH}$ on apical leakage. J. Endod., v.19, n.9, p.435-9, Sept. 1993.

98 TANOMARU FILHO, M. et al. Capacidade seladora do Sealer 26 e AH plus em obturações retrógradas. Rev. paul. Odont., ano XXI, n.1, jan./fev. 1999. 
TANOMARU FILHO, M.; MENDONÇA, T.A.; TANOMARU, J.M.G. Adaptação de materiais utilizados no selamento de perfurações radiculares. Análise em microscopia eletrônica de varredura. J. bras. endo/perio, v.2, n.5, p.107-10, abr./jun. 2001.

100 TAYLOR, M.J.; LYNCH, E. Microleakage. J. Dent., v.20, p.3-10, 1992.

101 TIDMARSH, B.G. Accidental perforation of the roots of teeth. J. oral Rehab., v.6, n.3, p.235-40, July. 1979.

102 TORABINEJAD, M. et al. Antibacterial effects of some root end filling materials. J. Endod., v.21, n.8, p.403-06, Aug. 1995.

103 TORABINEJAD, M. et al. Bacterial leakage of mineral trioxide aggregate as a root-end filling material. J. Endod., v.21, n.3, p.109-12, Mar. 1995.

104 TORABINEJAD, M. et al. Citotoxicity of four root end filling materials. J. Endod., v.21, n.10, p. 489-92, Oct. 1995.

105 TORABINEJAD, M. et al. Comparative investigation of marginal adaptation of mineral trioxide aggregate and other commonly used root-end filling materials. J. Endod., v.21, n.6, p.295-99, June. 1995.

106 TORABINEJAD, M. et al. Dye leakage of four root end filling materials: effects of blood contamination. J. Endod., v.20, n.4, p.159-63, Apr. 1994. 
107 TORABINEJAD, M. et al. Histologic assessment of mineral trioxide aggregate as a root-end filling in monkeys. J. Endod., v.23, n.4, p.225-8, Apr. 1997.

108 TORABINEJAD, M. et al. Investigation of mineral trioxide aggregate for root-end filling in dogs. J. Endod., v.21, n.12, p.603-08, Dec. 1995.

109 TORABINEJAD, M. et al. Physical and chemical properties of a new rootend filling material. J. Endod., v.21, n.7, p.349-53, July. 1995.

110 TORABINEJAD, M. et al. Tissue reaction to implant Super-EBA and mineral trioxide aggregate in the mandible of guinea pigs: a preliminary report. J. Endod., v.21, n.11, p.569-71, Nov. 1995.

111 TORABINEJAD, M. et al. Tissue reaction to implanted root-end filling materials in the tibia and mandible of guinea pigs. J. Endod., v.24, n.07, p.468-71, July. 1998.

112 TORABINEJAD, M.; CHIVIAN, N. Clinical applications of mineral trioxide aggregate. J. Endod., v.25, n.3, p.197-205, Mar. 1999.

113 TORABINEJAD, M.; WATSON, T.F.; PITT FORD, T.R. Sealing ability of a mineral trioxide aggregate when used as a root end filling material. $\mathbf{J}$. Endod., v.19, n.12, Dec. 1993.

114 VINHOLES, J.I.A.M. Tratamento das perfurações na região de furca: estudo comparativo. Pelotas, 2000. 104p. Dissertação (Mestrado) Faculdade de Odontologia, Universidade Federal de Pelotas. 
115 WELDON JR., J.K. et al. Sealing ability of mineral trioxide aggregate and Super-EBA when used as furcation repair material: a longitudinal study. J. Endod., v.27, n.3, p.218, Mar. 2001. /Abstract n.16/.

116 WU, M.-K. et al. Fluid transport and bacterial penetration along root canal fillings. Int. Endod. J., v.26, n.4, p.203-8, July 1993.

117 WU, M.-K.; KONTAKIOTIS, E.G.; WESSELINK, P.R. Decoloration of 1\% methylene blue solution in contact with dental filling materials. J. Dent., v.26, n.7, p.585-9, Sept. 1998.

118 WU, M.-K.; KONTAKIOTIS, E.G.; WESSELINK, P.R. Long-term seal provided by some root-end filling materials. J. Endod., v.24, n.8, p.557-60, Aug. 1998.

119 WU, M.-K.; WESSELI NK, P.R. Endodontic leakage studies reconsidered. Part I. Methodology, application and relevance. Int. Endod. J., v.26, n.1, p.37-43, Jan. 1993

120 YACCINO, J.M. et al. Longitudinal microleakage evaluation of Super-EBA as a root-end sealing material. J.Endod., v.25, n.8, p.552-4, Aug. 1999.

121 YAMASHITA, J.C. et al. Cimento endodôntico AH plus como material retroobturador: avaliação da capacidade de selamento apical, in vitro - relato de caso clínico. J. bras. Odontol. clin., v.3, n.18, p. 70-3, 1999. 
122 YAMAZAKI, Y. et al. Response of mouse femoral muscle to an implant of a composite of bone morphogenetic protein and plaster of Paris. Clin. Orthop., v.234, p.240-9, 1988. apud MITTAL, M.; CHANDRA, S.; CHANDRA, S. An evaluation of plaster of Paris barriers used under various materials to repair furcation perforations (in vitro study). J. Endod., v.25, n.5, p.385-8, May. 1999.

123 YATSUSHIRO, J.D.; BAUMGARTNER, J.C.; TINKLE, J.S. Longitudinal study of the microleakage ok two root-end filling material using a fluid conductive system. J. Endod., v.24, n.11, p.716-9, Nov. 1998.

124 ZANETTI, R. et al. Estudo da performance do MTA como material retroobturador. Braz Oral Res, São Paulo, v.14, sp. Iss. p.44, 2000. (Abstract I258) 
A B ST RA CT 


\section{ABSTRACT}

\section{"SEALING CAPACITY AND MARGINAL ADAPTATION BY SOME MATERIALS WHEN UTILIZED UNDER FURCATION PERFORATIONS OF HUMAN MOLARS"}

This paper analyses the sealing capacity and the marginal adaptation in vitro of a few materials when utilized under furcal perforations. The experiment utilized a hundred and forty four extracted human mandibular and maxillary molars. From the total amount, eighty-eight were utilized for checking the sealing and sixteen for checking the marginal adaptation under M.E.V. The teeth had its crowns seccionated and removed in an upper level close to the top of the floor of the pulp chamber, and the roots close to the bottom of the furcal area. Following that, there was an impermeabilization of the whole external surface of the specimens, and the inclusion in a heavy silicon base. There was a $1.4 \mathrm{~mm}$ perforation to the center of the floor of each specimen. Up front to the perforation, in the silicon base, depressions were made and little cotton pellets moisturized with distilled water were positioned before the obturation. In each group, subgroups were created. One receiving a Plaster of Paris matrix and the other no. The obturation of perforations were then, made with the following materials: Group I (MTA - Angelus), Group II (ProRoot MTA), Group III (Super-EBA), Group IV (MBP-c). After that, the specimens were submerged in a rhodamine B $0,2 \%$ solution at $37^{\circ} \mathrm{C}$, for 48 hours. After cleaning the roots and removing the impermeabilization, they were seccionated in the axis direction, thus revealing the perforations and possible leakage marks. The reading of 
the marginal adaptation was performed by an optical microscope utilizing numerical scores $0,1,2$ e 3 . In order to visualize the marginal adaptation of the obturation materials in regards to the dentinal walls, the specimens were introduced to the same methodology as described before, except for the steps of impermeabilization of the external surface and the submerging in dye. After cement placement, the M.E.V was applied and photos with 50X e 200X were obtained. The results regarding the marginal infiltration were statistically tested. Thus allowing the following conclusions: when isolated and tested (without the matrix), the cement MBP-c presented the smallest coefficient of marginal leakage, followed by the Super-EBA. There was a statistical significance between those and the cements ProRoot - MTA e MTA - Angelus $(p<0,001)$. In the presence of the Plaster of Paris matrix, the cement MBP-c presented the smallest levels of marginal leakage, having statistical significance between those and the cements ProRoot - MTA e MTA - Angelus $(p<0,05)$; There was a significant statistical variation, in the marginal leakage of the cements due to the presence of the Plaster of Paris matrix to the Super-EBA and to MBP-c $(p<0,05)$. The utilization of the Plaster of Paris matrix avoided the leakage of the sealing materials. A direct relationship could be found between the marginal adaptation and the material sealing capacity. 


\author{
Universidade de São Paulo \\ Faculdade de Odontologia de Bauru \\ Al. Dr. Octávio Pinheiro Brisolla, 9-75 - Bauru-SP - CEP 17012-101 - C.P. 73 \\ PABX (0XX14)235-8000 - FAX (0XX14)223-4679 \\ Comitê de Ética \\ e-mail: anacapel@fob.usp.br-Fone: (0XX14)235-8254
}

Bauru, 5 de março de 2002.

Senhor professor,

O projeto de pesquisa encaminhado a este Comitê de Ética denominado "Capacidade seladora e adaptaçăo marginal propiciadas por alguns materiais quando utilizados em perfuraçőes na região de furca." , de autoria do C.D Ulisses Xavier da Silva Neto desenvolvido sob sua orientação, foi avaliado e recebeu parecer do relator aprovando o trabalho, na reunião de 26 abril de 2001 foi APROVADO por este Comitê.

Durante o desenvolvimento do trabalho, houve uma alteração no titulo do trabalho para: "Capacidade Seladora e adaptação marginal proporcionadas por alguns materiais quando utilizados em perfuraçōes na regiăo de furca de molares humanos."

Informamos que após o envio do trabalho concluido este comité enviará o parecer final, que será utilizado para a publicação do trabalho.

Atenciosamente,

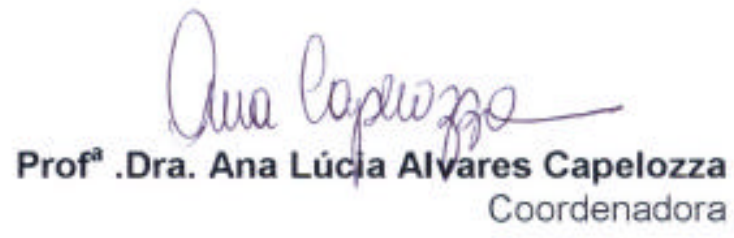

II. mo Senhor

Prof. Dr. Ivaldo Gomes de Moraes 